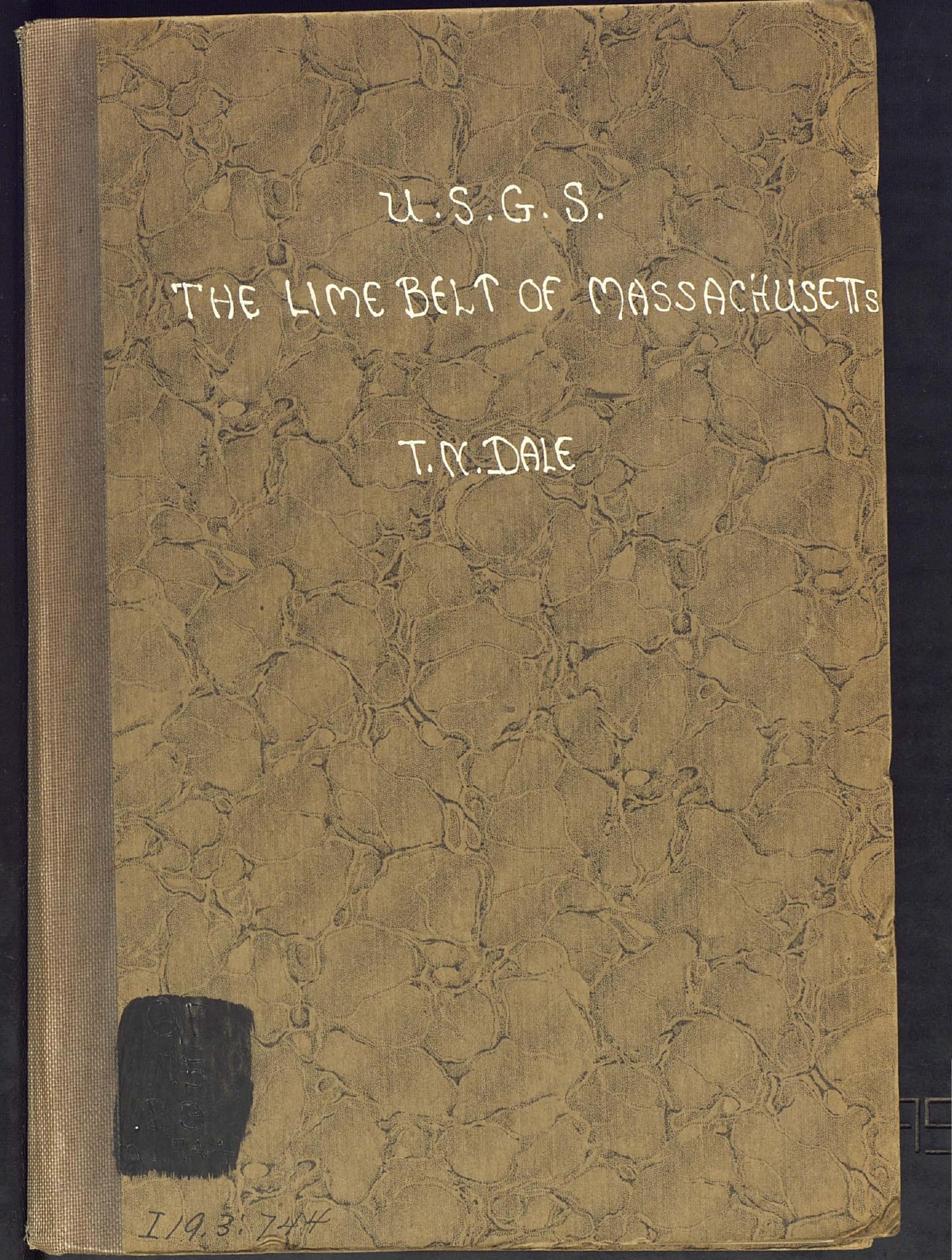




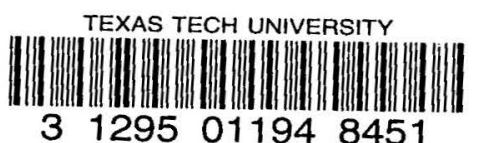


Please do not destroy or throw away this publication. If you have no further use for it, write to the Geological Survey at Washington and ask for a frank to return it

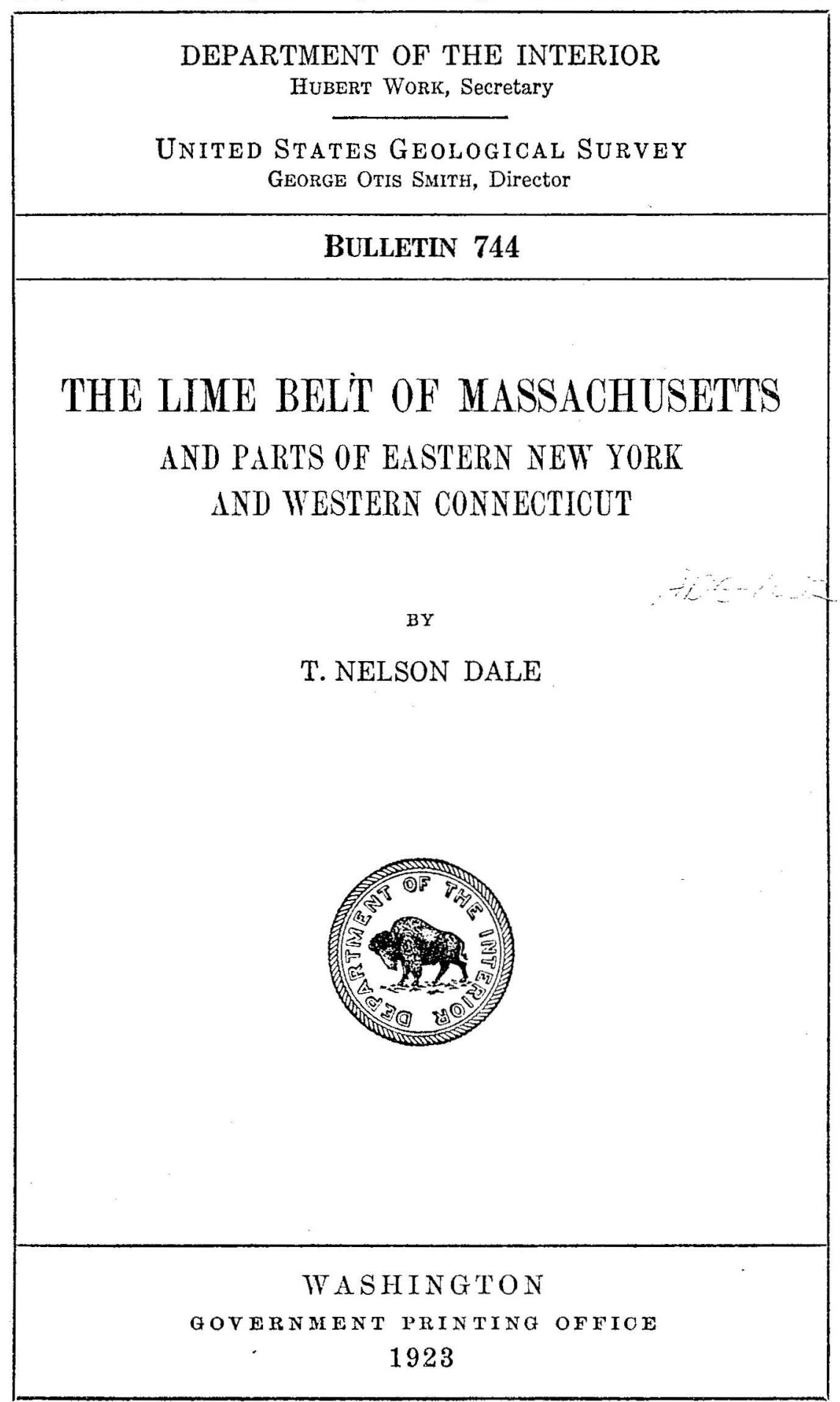



DEPARTMENT OF THE INTERIOR

HUBERT WORK, Secretary

United States Geological Survey

George Otis SMith, Director

Bulletin 744

\section{THE LIME BELT OF MASSACHUSETTS}

AND PARTS 0F EASTERN NEW YORK AND WESTERN CONNECTICUT

BY

T. NELSON DALE

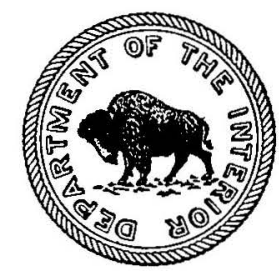

LIPAARM

TEXAS TECHNOLOEICAL COLLEOE

LUBBUCir, i EXAS

G30:12

WASHINGTON

GOVERNMENT PRINTING OFFIOE

1923 
ADDITIONAL COPIES

OF THIS PUBLICATION MAY BE PROCURED FROM

THE SUPERINTENDENT OF DOCUMENTS

GOVERNMENT PRINTENG OFFICE

WASHINGTON, D. C.

$A T$

30 CENTS PER COPY

PURCHASER AGREES NOT TO RESELL OR DISTRIBUTE THIS COPY FOR PROFIT.-PUB. RES. 57, APPROYED MAY 11, 1922 


\section{CONTENTS.}

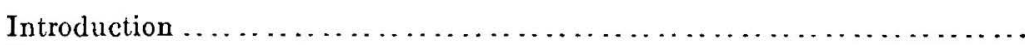

General geologic relations . . . . . . . . . . . . . . . . . . . . . . . .

A real distribution of calcitic and dolomitic limestone $\ldots \ldots \ldots \ldots \ldots \ldots \ldots$

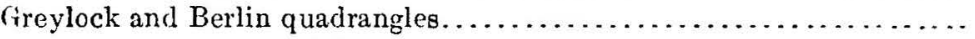

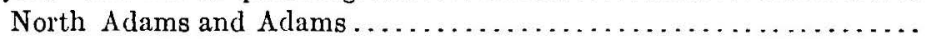

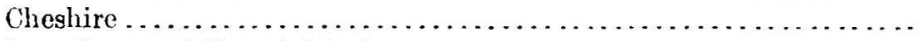

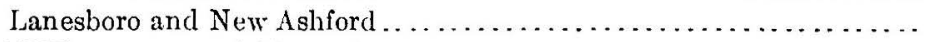

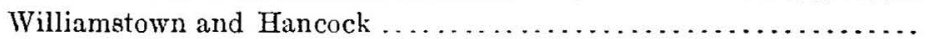

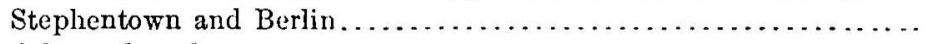

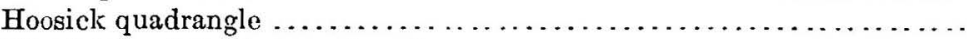

Pittsfield and Becket quadrangles . . . . . . . . . . . . . . . . . .

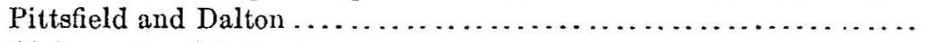

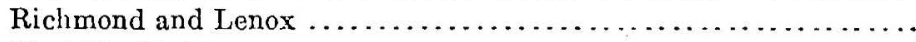

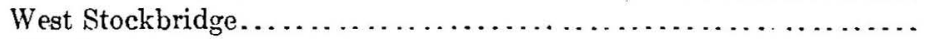

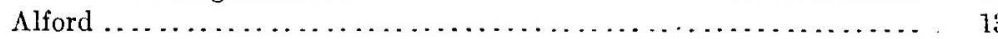

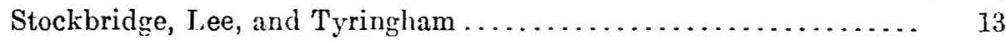

Canaan, New Lebanon, and A usterlitz.................... 14

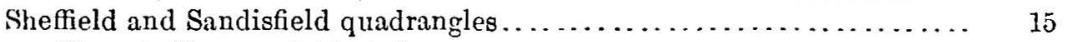

Taconic Range calcitic belt ............................ 15

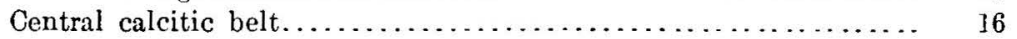

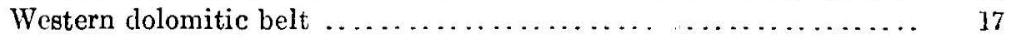

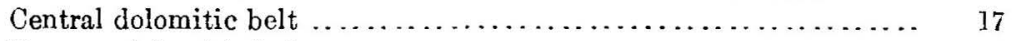

Eastern dolomitic belt.................................... 17

West foot of Taconic Range in Hillsdale, N. Y............... 18

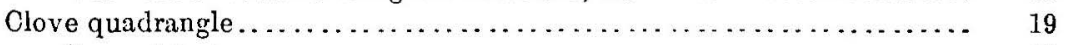

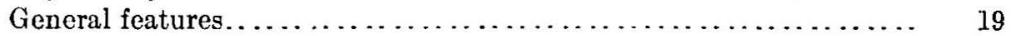

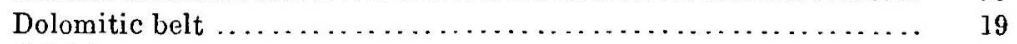

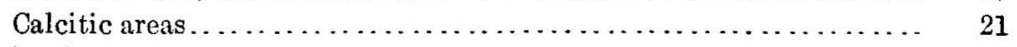

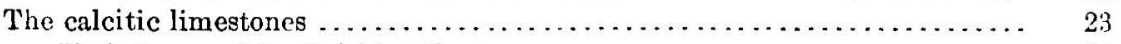

Varieties used for finishing lime............................ 24

Varieties regarded as not making the best finishing lime ............. 25

Varieties discarded on account of accessory minerals ............... 25

Varieties discarded on account of texture or content of magnesia . . . . . . 27

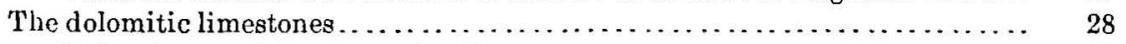

Dolomites used for magnesian lime ......................... 28

Varieties discarded on account of accessory minerals............. 30

Variety discarded on account of behavior under fire............. 31

Granular and semigranular dolomitic limestones . . . . . . . . . . . . . . $\quad 32$

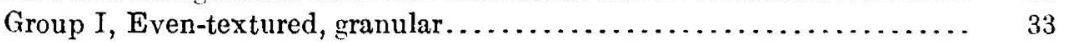

Group II, Uneven or porphyroid texture, granular.............. 36

Group III, Semigranular.............................. 40

Granular calcitic limestone and associated dolomite $\ldots \ldots \ldots \ldots \ldots \ldots \ldots, 42$ 


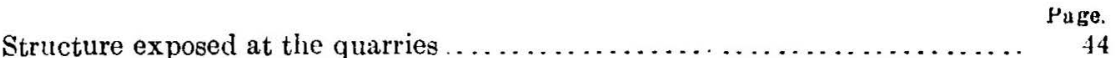

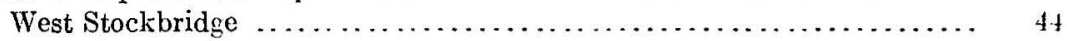

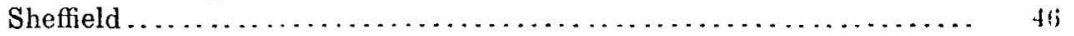

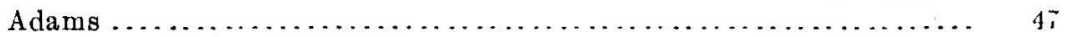

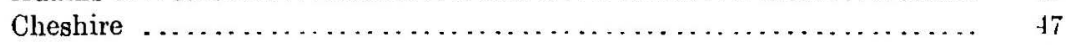

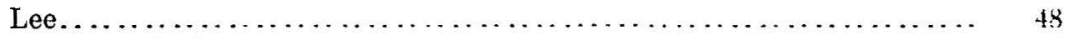

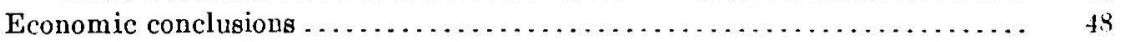

Significance of amount of discarded rock ..................... tis

Siguificance of geologic structure $\ldots \ldots \ldots \ldots \ldots \ldots \ldots \ldots \ldots \ldots \ldots \ldots \ldots+\ldots \ldots$

Prospecting for limerock in this region....................... 49

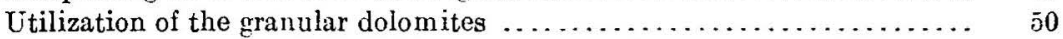

Maximum grade of texture for use in upright kilns ............. 50

Utilization of the granular calcitic limestone................... 50

Scientific conclusions. . . . . . . . . . . . 50

Relations of dolomite and calcite in the Stockbridge limestone as bearing

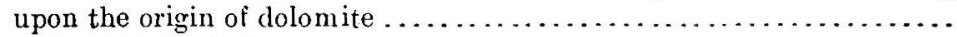

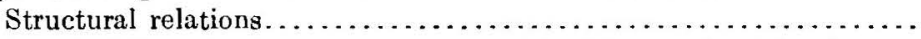

Interbedding of twinned calcite (marble) with granular dolomite....

lnterbedding of twinned calcite and twinned dolomite rock.........

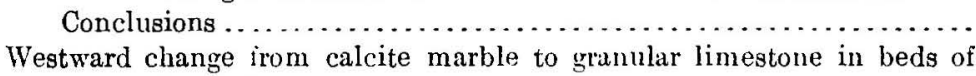

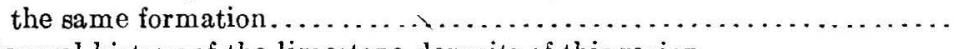

General history of the limestone deposits of this region . . . . . . . . . . .

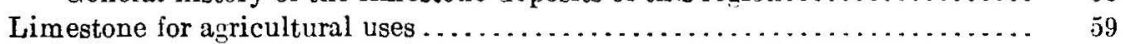

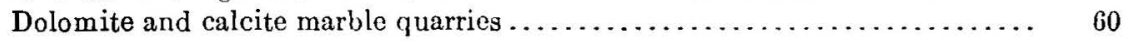

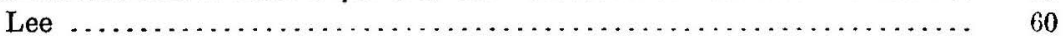

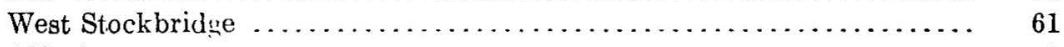

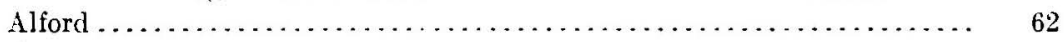

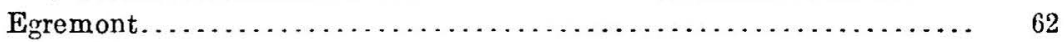

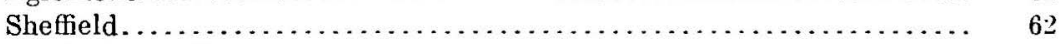

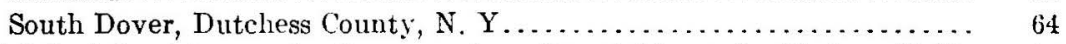

A slightly dolomitic granular limestone irom Becrait Mountain, Hudson, N. Y. 64

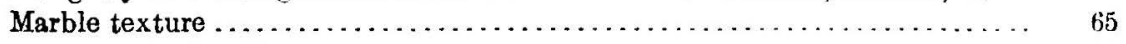

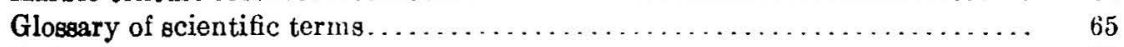

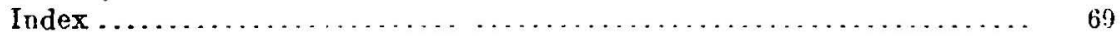




\section{ILLUSTRATIONS.}

P's.ste 1. Map of Greylock and Berlin quadrangles, Massachusetts and New

York, showing areas of calcitic and dolomitic limestone.... In pocket.

II. Map of Pittsfield and Becket quadrangles, Massachusetts and New York, showing areas of calcitic and dolomitic limestone.... In pocket.

III. Map of Sheffield and Sandisfield quadrangles, Massachusetts, Connecticut, and New York, showing areas of calcitic and dolomitic

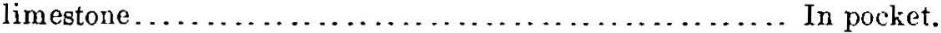

IV. Map of Clove quadrangle, New York, showing areas of calcitic and dolomitic limestone.......................... In pocket.

V. A, Miller quarry, west opening, West Stockbridge, Mass.; $B$, Anticline of dolomite and calcite, Truesdell quarry (north), West Stockbridge, Mass.

VI. A, Miller quarry, east opening, West Stockbridge, Mass.; $B$, Miller quarry, central opening, West Stockbridge, Mass.............

VII. Structure on south wall of Lee Ijime Co.'s quarry, Lee, Mass.......

VIII. A, Granular calcite limestone with nodules of granular dolomite, Hancock, Mass.; $B$, Lime with magnetic black spherules obtained from pyritiferous dolomite.

Sketch of surface of granular calcite limestone with lenses of granular dolomite in the bedding, Petersburg Junction, N. Y......

2. Thin section of quartzose and micaceous twinned calcite rock,

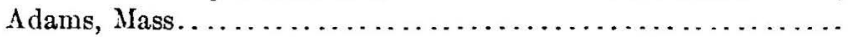

3. Thin section of semigranular dolomite, Kelley Island Lime \& Transport Co.'s quarry, Dover Plains, X. Y.

4. Thin section of twinned dolomite, disused quarry, Dover Plains, N. Y.

5. Thin section of granular dolomite, Charles Reed place, Great Barrington, Mass.

6. Thin section of granular dolomite associated with granular calcite limestone, Canaan, N. Y

7. Thin section of granular dolomite, Hillsdale, N. Y . . . . . . . .

8. Thin section of granular dolomite, Phelps Knoll, near South Williamstown, Mass.

9. Thin section of porphyroid granular dolomite, near Monterey,

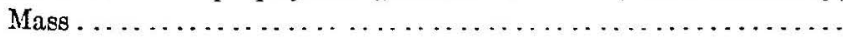

10. Thin section of porphyroid irranular dolomite, Standard Lime Co.'s quarry, Lee, Mass

11. Thin section of white porphyroid granular dolomite, openingr near Upton's, Adams, Mass

12. Thin section of semigranular dolomite, southwest foot of Rattle-

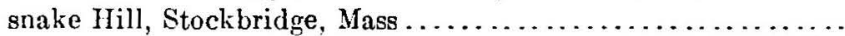

13. Thin section of granular calcite limestone, Berlin, N. Y ........

14. Thin section of nodule of granular dolomite in granular calcite limestone, Hancock, Mass. 
Figure 15. Structure at New England Lime Co.'s quarry, West Stockbridge,

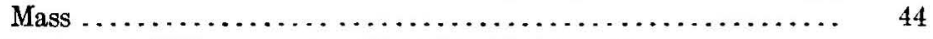

16. Structure at Miller quarries, West Stockbridge, Mass ........ 4 j

17. Hypothetical structure at Tohey I.ime quarry, West Stockbridge, Mass.................................... 45

18. Structure at Truesdell quarry (south), West Stockbridge, Mass... 46

19. Structure at Massachusetts Lime Co.'s quarries, Sheffield, Mass.. 46

20. Structure on south wall of Renfrew quarry, Adams, Mass....... 47

21. Structural details in central part of south wall, I ee I.ime Co.'s quarry, I.ce, Mass ............................ 48

22. Thin section of specimen from quarry near Salisbury, Conn..... 54

23. Outline of surtace and structural data of east foot of Maple Ifill, west of Stockbridge Marble Works quarry, Mass............ 


\title{
THE LIME BELT OF MASSACHUSETTS AND PARTS OF EASTERN NEW YORK AND WESTERN CONNECTICUT.
}

\author{
By T. Nelson Dale.
}

\section{INTRODUCTION.}

Although the geology of the lime-producing western parts of Massachusetts and Connecticut has been studied for many years, even the last published geologic maps, that of Massachusetts by Emerson ${ }^{1}$ and that of Connecticut by Gregory and Robinson, ${ }^{2}$ make no distinction between the calcitic or "high calcium" and the dolomitic or "high magnesium" limestone but show all limestone in one color under the formation name "Stockbridge limestone" (Cambrian and Ordovician). The same formation extends through western Vermont, but a map of that region prepared by the writer ${ }^{3}$ separates the two limestones, at least in their larger areas.

Although both of these limestones are sometimes used for the same purposes in the lime industry, each has properties that specially fit it for certain uses. The most desirable location for a kiln would be near the boundary between both kinds of rock. Several kilns in the States named were evidently located without the aid of a geologic map, and there is much uncertainty among the operators as to the distance of their kilns from the nearest outcrop of the kind of limestone which they are not quarrying but which they may desire to quarry. For these reasons a geologic map of the region showing approximately the boundaries of the calcitic and the dolomitic limestones is of economic value.

In order to meet this demand, the writer spent the summer of 1918 in tracing these boundaries in Berkshire County, Mass., and in Salisbury and North Canaan, in Litchfield County, Conn. The summer of 1919 was spent in completing these boundaries in Berkshire County and in extending them westward into Rensselaer and Columbir counties, N. Y. The Stockbridge limestone in the townships of Dover and Pawling, in Dutchess County, N. Y., was also subdivided.

\footnotetext{
1 Imerson, B. K., Geology of Massachusetts and Rhode Islind: C. S. Geol. Survey Bull. 597, pl. 10, 1917.

1 Gregory, H. E., and Robinson, H. H., Preliminary geologic map of Connecticut: Comnecticut Geol. and Nat. Hist. Survey Bull. 7, 1907.

${ }^{3}$ Dale, 'T'. N., The commercial ulurbles o western Vermont: T'. S. Geol. Survey Bull. 521, pl. 1, 1912.
} 
The results of all this work are shown on the accompanying four maps, upon which also the locations of quarries and kilns are given. The boundaries between the Stockbridge limestone and the adjacent areas of older and younger formations have been taken from maps prepared for folios of the Geologic Atlas of the United States by Professors Wolff, Hobbs, Barrell, Emerson, and the writer.

The Stockbridge limestone is irregular in both composition and structure. The lower part is generally dolomitic and the upper part calcitic, but there is some interbedding of the two varieties in the upper part, and more rarely the lower part occurs where the upper part would be expected. There are also other mineral changes in both parts, and the folding of the beds throughout the formation is generally intricate. Furthermore, the Stockbridge limestone merges on the west in a granular calcitic limestone containing lenses and beds of granular dolomite.

In order to throw more light upon this complex problem, specimens of the beds were collected at the quarries for microscopic study, and the intricate structure seen at the quarries was studied and sketched or photographed. A number of careful analyses of dolomitic rocks, some used, some discarded, and others that may prove serviceable, were made by J. G. Fairchild, a chemist of this Survey, and are now published. The writer has added some microdrawings and geometric analyses. E. S. Larsen has determined the mica, which is phlogopite.

Incidentally to this economic work some data of scientific interest bearing upon the origin of calcite and dolomite and their crystalline relations were obtained and are summarized. A brief outline of the geologic history of the limestones and their associated beds is also given. Supplementary to the subject proper of this bulletin are a discussion of the application of limestone or lime to the soil, with a brief note on a quarry of limestone for direct agricultural use; descriptions of several marble quarries in Massachusetts and of one in Dutchess County, N. Y.; and a description of a slightly dolomitic granular limestone typical of an unmetamorphic region near Hudson, N. Y.

A glossary of scientific terms is given at the end of the report. The numbers given to the specimens are those of the original specimens and thin sections at the National Museum, and the numbers of the localities referred to in the text are those given on the maps.

\section{GENERAL GEOLOGIC RELATIONS.}

The problems connected with the locations of quarries for the lime industry in this region can not be solved without an understanding of the general geologic relations. 
The oldest sedimentary rocks in the lime-producing belt are the Lower Cambrian metamorphosed sandstones represented by Rattlesnake Hill in Stockbridge and underlying the cliffs of Monument Mountain in Great Barrington (here designated Horizon I). This rock is in places, as on Monument Mountain, overlain by pure quartz sandstone (quartzite), but in other localities the quartzite takes its place, as along the foot of the Green Mountain Range between Williamstown and North Adams. On the rocks of Horizon I lay originally a considerable thickness (500 to 800 feet) of dolomitic limestone (Horizon II), represented by the area about Williamstown, the strip between North Adams and Adams, and large areas about Pittsfield and in Great Barrington and Sheffield. Above this in turn is a mass of calcitic limestone (Horizon III) with here and there some interbedded dolomite. The total thickness of the rocks representing Horizon III is 200 to 400 feet. The beds of Horizons II and III are known technically as the Stockbridge limestone, although some of the beds are marble.

Along a north-northeasterly line parallel to the New York-Massachusetts boundary but near the east foot of the Taconic Range the Stockbridge limestone, at the surface mainly Horizon III but possibly including some of Horizon II, merges westward in a mass of granular calcitic limestone containing lenses of granular dolomite onetenth of an inch to 18 inches thick or beds of it several feet thick. In places this granular limestone is slightly magnesian, containing some minute rhombs of dolomite; exceptionally the calcite grains are elongate and mostly twinned and with them are some clouded dolomite grains, rarely twinned, the rock being thus a slightly dolomitic calcite marble of grades 1 to 3 . (See table of grades, p. 65.)

This is followed by a mass of metamorphosed clay, mica schist (Horizon IV), of which the greater part of Mount Greylock, also Mount Everett and West Stockbridge and Lenox mountains, consist and which has a maximum thickness of half a mile. In places, owing either to local irregularity of sedimentation or else to a local unconformity, the dolomite of Horizon II lies immediately under the schist, as in Cheshire, Lanesboro, and Williamstown (PI. I). The calcitic limestone quarries of Adams, North Adams, and West Stockbridge are in Horizon III; the quarries of Lee, Mass., and North Canaan, Conn., are in Horizon II. The series of sedimentary rocks in the lime belt of Dover and Pawling, in Dutchess County, N. Y., is similar to that in western Massachusetts and Connecticut, and the quarries are in IIorizon II (Pl. IV).

As these rocks have been powerfully corrugated, presumably by the contraction of the outer portion of the planet, none of the strata retain their original horizontality, and, owing to the varying amount of planing and gouging by erosion which the original corrugations 
have undergone, the members of the series are very differently exposed at different points. This irregularity of exposure is further increased by two features: (1) The axes of the corrugations are not everywhere horizontal but pitch at intervals in opposite directions, so that members of the series disappear under overlying members in the direction of the axes and also farther on emerge from beneath such members. (2) Owing to extreme or renewed compression the whole series of beds has been faulted here and there in different directions, as on the three sides of Monument Mountain (PI. II), beds of different ages being thus brought into juxtaposition at the same level.

A practical difficulty pertaining to all glaciated regions should be mentioned. The glacier and the lakes to which it gave rise have deposited masses of gravel and sand and beds of clay, which in places cover the rock with an overburden too thick to warrant its removal. The morainal masses in the village of Adams are a striking exhibit of this obstacle. The accompanying maps show the approximate areal extent of the two limestones, although large parts of their respective areas are covered with glacinl deposits and soil.

\section{AREAL DISTRIBUTION OF CALCITIC AND DOLOMITIC LIMESTONE.}

\section{GREYLOCK AND BERIIN QUADRANGLES.}

[Sec PI. I.]

North Adams and Adams.-There is a calcitic series (Horizon III) immediately under and east of the schist on the Greylock side of the Hoosic Valley and in presumably similar relation west of the schist between North Adams and Briggsville. It was quarried in North Adams west of the station, where the beds are nearly vertical, and also about a mile south, and is now quarried near the Natural Bridge. From a point about 2 miles south of North Adams southward the limerock is covered with glacial deposits, and only the schist is exposed; but west of the Zylonite Mill the calcitic beds reappear and the schist boundary turns west for a quarter of a mile and sends out a narrow schist tongue half a mile to the south. In the calcitic area west of this tongue lies the quarry of the Hoosac Valley Lime Co., and farther south the abandoned quarry of the Adums Marble Co. Some of the discarded blocks here show interbedded calcite and dolomite. About 900 feet a trifle west of south from the end of the schist tongue is the Renfrew quarry of the New England Lime Co. The calcitic belt continues south to Pecks Brook with an east and west width of 1,000 to 1,800 feet. Important calcite marble outcrops occur half a mile south of Pecks Brook at localities 148 and 32, west of the small schist outlier.

At a point about 725 feet north of the west end of Newark Street, Zylonite, a belt of dolomitic limestone begins. A building-stone 
quarry was opened near that point many years ago. The belt here is about 625 feet wide. It is covered with glacial deposits to the south but reappears in small eastward-trending gullies west of the New England Lime Co.'s kiln. The most eastern outcrop of it is 150 feet from the kiln, and the most western one about 1,150 feet west of the first. The dolomite is granular and becomes somewhat quartzose and micaceous near its contact with the calcitic belt. (See further, p. 50.)

The next outcrops of the dolomite are about $1 \frac{1}{8}$ miles south of Newark Street, near the Upton house (locality 160), where it has been quarried in a small way. It crops out a little north of the Friends' Cemetery on both sides of the road, and again about half a mile farther south. The last outcrop is on the east side of the knoll about 1,000 feet north of Pecks Brook (locality 251). The calcitic limestone crops out 70 feet west of the dolomite and has been quarried near by. This dolomitic belt probably pitches under the calcitic belt between the latitude of locality 251 and Pecks Brook.

The dolomite recurs on the east side of the valley on the west flank of Hales Hill along the road running south from Adams. The calcitic belt is represented by white marble of texture grade 5 (see table on p. 65) on the farm of E. S. Wood (locality 44), and the dolomite has been quarried at locality 46 , opposite the ancient Brown farmhouse. The next outcrops of this rock are along Anthony Creek (locality 43) 0.4 mile east of the railroad and at the west portal of the Hoosac Tunnel and northwest of it (locality 38), between the railroad and the schist on the northeast. On the map the dolomite is represented as probably underlying the Hoosic Valley as far as North Adams and also the valley of the North Branch, between the calcitic belt of Briggsville and the quartzite of Clarksburg, and also beyond in Stamford, Vt.

Cheshire.-Another considerable area of dolomite lies in Cheshire north and south of the village, but its areal and structural relations for a space of 2 miles differ from those of the Adams area. Kitchen Brook east of the Greylock schist mass passes through a small canyon of dolomite about 1,000 feet long. About a mile southwest, in the bed of a small brook flowing into the reservoir, there are almost continuous outcrops of various dolomitic limestones from the 1,100-foot level west to the schist mass with which the dolomite is in contact. Outcrops of dolomitic limestone occur here and there southward for another mile. One of these is close to the mouth of the quarry tunnel; others are a quarter of a mile to the south. The dolomite thus occupies here the place of the calcitic limestone in its relation to the overlying schist. The causes of this are discussed on page 3. But half a mile farther south, as shown on the map, the calcite rock recovers its normal place and the dolomite disappears. 'The mapped 
course of the boundary opposite Farnam is governed by the results of core drilling a little south of Farnam post office.

The dolomite area shown north of Cheshire village is represented by but few outcrops. The best of these is at locality $27,1 \frac{1}{1}$ miles north-northeast of the station. The calcite marble crops out in Bassett Brook west of Cheshire Harbor and also half a mile westsouthwest of the station.

Lanesboro and New Ashford.--Dolomite crops out in the village of Berkshire south of Cheshire Reservoir and off and on for a mile to the south. The conspicuous hillock known as Briggs Cobble, 1 mile about west of Berkshire station, consists of low dipping granular dolomite underlain at the east foot by coarse calcite marble of which only the upper 10 feet is exposed. Although this dolomite is in line with that west of Farnam there is no evidence of their connection at the surface, so a continuous calcitic area is represented on the map as extending from the reservoir to the schist ridge on the west. In this area is the large calcitic outcrop a mile northeast of the Cobble. Still on the east side of the valley and half a mile north of the Pittsfield line is a conspicuous linoll of granular dolomote. The calcitic belt east of the Greylock mass narrows and dies out not far from the Lanesboro-Pittsfield line.

West of the Greylock schist mass, north of Lake Pontoosuc, the dolomite replaces the calcitic series and continues for about 2 miles north of Lanesboro village. Then the calcitic series takes its normal place and finally dips under the schist of Pratt Hill at the north.

The calcite marble crops out from under the schist at the southeast foot of East Mountain and along the east foot of Potter Mountain. At locality 114 , about 375 feet $\mathrm{N} .70^{\circ} \mathrm{W}$. from the marble boulder known as Balance Rock, the white calcite marble strikes N. $25^{\circ} \mathrm{E}$. That boulder rests upon another with beds striking N. $75^{\circ} \mathrm{W}$., and there is a large group of smaller boulders a few rods away. ${ }^{*}$ At locality 115 , south of Laurel Hill, the calcite marble is almost in visible contact with the schist of Horizon IV. The marble, here dark gray, consists of twinned calcite of texture grades 3 to 4 , with streaks of untwinned grains, probably dolomite, of grade 0.1 , with quartz, muscovite, pyrite, and graphite, and is interbedded with white granular dolomite of grade 0.1. North and west of Lake Pontoosuc the dolomite appears and narrows the calcitic belt along the Taconic Range to a quarter of a mile.

In New Ashford calcitic limestone, mostly marble, is intricately interlaced with schist. In places it forms inliers in the schist or the schist forms outliers in the marble. This calcite marble is the same

4 At locality 118 lies probably the largest marble boulder in New England. It measures about 42 by 19 feet and 15 feet high. The marble is in very large plications like that on the Noppet, nearly half a mile N. $10^{\circ} \mathrm{E}$., from which it was probably detached and transported by the glacier. 
as that on the Noppet and about Constitution Hill, and in the area between these hillocks.

Williamstown and Hancock.-The map shows a belt of calcitic limestone beginning in North Adams and continuous there with that on the east side of the Greylock mass, skirting the west side of the schist for a maximum width of about 1,000 feet. It crops out at the north foot of Mount Williams (a little east of the Williamstown line) and at the northwest corner of Prospect Mountain on the 1,160-foot level, about 200 feet above the little reservoir and only 20 feet lower than the schist (locality 7). It continues southwest to the Hopper cut. The rock is generally a calcite marble and has been quarried for lime in recent years at two points (localities 3 and 11 , between the 1,200 and 1,250 foot levels) and was carted almost 2 miles to the railroad at Blackinton. At locality 3 the marble has fine brownishtinted bands which under the microscope resolve themselves into granular dolomite (?), pyrite oxidized (accounting for the color), and a few grains of quartz and feldspar with little mica (muscovite). Although the amount of pyrite was small it probably proved sufficient to detract from the value of the lime. At locality 11 the rock is a light-gray calcite marble of texture grade 5 (coarse), with a little quartz but no pyrite. As will be noticed on the map, there must be a considerable thickness of calcite marble between these openings and the schist, which is 700 feet away and 300 feet higher. The marble crops out again three-quarters of a mile to the southeast, in the hollow north of the Fowler (now Sweet) House, through which flows a brook that reaches Green River near Sweets Corner. If it is practicable to use calcite marble from such a location for the lime industry the belt of Horizon III on the northwest side of the Greylock mass should be carefully prospected up to the schist boundary (Horizon IV) or the line of the Greylock Reservation.

At the southwest shoulder of Prospect Mountain near the 1,300foot level, the lower boundary of the calcitic belt turns westward to meet the fault line east of Deer Hill. Calcite marble has been prospected at locality $46 \frac{1}{2}$, on the 1,200 -foot line on the Ward farm. Calcite marble crops out also on the south side of the Hopper near the schist, and there is an inlier of it in the schist mass south of Hopper Brook.

The next considerable strip of calcitic limestone is on the west side of Deer Hill (localitics 58, 59), east of South Williamstown. These are white calcite marbles of texture grade 4 (medium). Belonging to the same belt are the extensive calcite marble outcrops on the Galusha farm on the north foot of South Mountain between the 1,060 and 1,300 foot levels. Among these is an isolated mass of granular dolomite (locality 63) 50 to 75 square feet in area that probably belongs to a bed in the calcitic series. 
At some point between the calcitic marble of the Galusha farm and locality 75 about a mile north of it and 0.3 mile northwest of South Williamstown the marble passes into the dolomitic granular limestone described on page 42 ; but north of locality 75 the marble recurs along the north foot of Phelps Knoll and in Hemlock Brook (locality 23) near the schist. The point or line of transition from limestone to marble is undetermined. The lenticular aren of dolomite, nearly $1 \frac{1}{2}$ miles long, 0.4 mile west of South Williamstown is entirely surrounded by calcitic rock and is presumably of anticlinal structure. The texture of some of this dolomite is shown in figure 8 . The calcite marble north of Phelps Knoll has not been found north of the sharp bend in Hemlock Brook. At some point between this bend and Flora Glen dolomite takes the place of the calcite marble and immediately underlies the schist of Bee Hill, in the Taconic Range.

The dolomite is represented by a large number of outcrops of granular dolomite on the northwest flank of the Greylock mass below the calcitic belt. It also crops out along Green River to a point a mile south-southeast of South Williamstown. At locality 61, nearly half a mile southeast of South Williamstown, on the west side of Deer Hill, a quartzose granular dolomite has been quarried for road use.

On the west side of Stone Hill within a few hundred feet of Hemlock Brook, through an overturned fold, it underlies the Cheshire quartzite, the metamorphosed sandstone of Horizon I. It crops out in the village of Williamstown. North of Ford Glen and at the foot of Northwest Hill it takes the place of the calcitic limestone in relation to the schist.

The boundary between the calcite marble west of the dolomite lens near South Williamstown and the dolomitic granular calcite is uncertain owing to the scarcity of outcrops. The same uncertainty relates to the boundary between the calcite marble at the north foot of East Mountain and the dolomitic granular calcitic limestone along its west foot. In the valley of the West Branch of Green River about half a mile north of the Hancock line (locality 72) the calcitic limestone is a fine-textured gray marble with fine streaks and large lenses of granular dolomite. At locality 73 there is an outcrop of dolomite, but a few hundred feet east-northeast of it is the calcitic limestone. $\Lambda$ typical specimen of the dolomitic granular calcite rock of this valley, from locality 69, in Hancock, is shown in Plate VIII, $A$, and is described on page 43 .

Stephentown and Berlin.-Dolomitic granular calcite limestone occupies the Stephentown-Berlin valley and sends out lateral ramifications as shown on the map. The rock was examined at several points. At the hill northeast of Stephentown station (locality 164) it consists of dark bluish-gray, thinly foliated granular calcite rock with beds of granular dolomite up to 4 feet thick. At locality 165, a mile to 
the north, it is a bluish-gray granular calcitic limestone. At locality 166 , on the east side of the small schist outlier (Butternut Hill), it is a bluish-gray granular calcitic limestone, interbedded with granular dolomite. At locality 161, between Center Berlin and Berlin, it is a thinly foliated light bluish-gray granular calcitic limestone interbedded with much jointed granular dolomite. The smooth surface of the limestone contrasts strongly with the deeply and variously incised dolomite projecting in bold relief on the weathered surface, owing to its.greater resistance to erosion. In places the two rocks merge or the dolomite is reduced to nodules, 1 inch to several inches in diameter, or to strings of them. Specimens from this locality are described on page 43. At locality 163, near Berlin village, the limestone is a quartzose granular calcite rock with a fine secondary lamination but with beds in small recumbent folds, a few inches in diameter, more or less faulted along their axes, which are parallel to the lamination.

\section{HOOSICK QUADRANGLE.}

The granular calcitic limestone of the Stephentown-Berlin valley stops at a point about a third of a mile north of Berlin village but reappears in the valley of the Little Hoosic 7 miles north-northeast, in the township of Petersburg. Its relations there to the schist of Horizon IV on the east and west are the same as at the south. The rock was examined at localities 167 and 168 , south of North

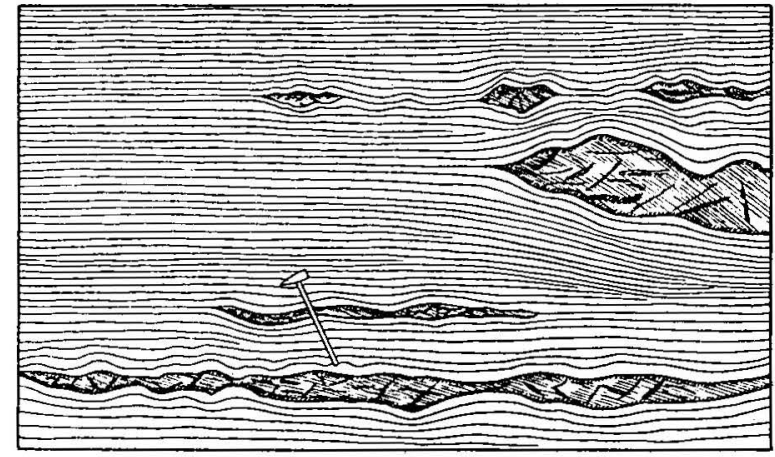

FIGURE 1.-Sketch of horizontal surface of granular calcite limestone with lenses of much jointed granular dolomite in the bedding. Dip $65^{\circ} \mathrm{E}$. Hammer handle 18 inches long. Location is 0.3 mile southsoutheast of Petersburg Junction, N.Y.

Petersburg, and again a mile north of locality 167 and at localities 169 and 170, near Petersburg Junction, in the Hoosic Valley. At locality 167 the rock is a bluish-weathering, dark, exceedingly finegrained granular limestone with carbonaceous or graphitic matter (p. 42). At locality 168 a similar rock contains a 4-foot bed of granular dolomite. At locality 169, 200 feet east of the railroad, it is the typical granular limestone with lenses of dolomite, with many fine intersecting joints along which atmospheric acid has carved gashes, adding to the roughness of their surface, as shown in figure 1. At the railroad cut here a 20-foot bed of granular dolomite contains small beds of granular limestone. At locality 170 , near the schist bound- 
ary, the granular limestone contains lenses and beds of granular dolomite 3 to 4 feet thick.

\section{PITTSFIELD AND BECKET QUADRANGLES.}

[See P].II.]

Pittsfield and Dalton.-The city of Pittsfield is underlain and surrounded by granular dolomite as shown on the map (PI. II). A core from 35 feet below the rock surface (specimen D, XXX, 92, a) at the Agricultural National Bank Building, near the center of the city, is a bluish-gray granular dolomite of grain diameter 0.025 to 0.17 millimeter, estimated average 0.05 millimeter, texture grade 1 (extra fine A). It contains a little mica, quartz, plagioclase feldspar, and pyrite. At locality 82 , about 1,000 feet south of the junction of the Boston \& Albany and New York, New Haven \& Hartford railroads, the rock is a very light bluish-gray granular dolomite of grade 1 and contains a little quartz, muscovite, pyrite, and feldspar. The granular dolomite extends north to Lake Pontoosuc, northwest to Lake Onota, southwest to Barkerville, ${ }^{5}$ and south probably to the New York, New Haven \& Hartford Railroad.

A little north of West Pittsfield station and east of the track (locality 96) the granular dolomite crops out, and a little west of it is the calcite marble and the opening to the abandoned limonite mine. The strike is $\mathrm{N} .50^{\circ}-65^{\circ} \mathrm{W}$. Although there are no outcrops to establish the continuity of these limestones with those at locality 122, 3 miles to the south-southwest (Pl. II), it is rendered somewhat probable by their strike of N. $20^{\circ} \mathrm{E}$. at that point. The continuity of this dolomitic belt northward is highly probable from outcrops at localities $88,83,85$, and 87 . The one at locality 87 is a knoll, half a mile about west of the "Radium Spring," of granular dolomite of texture grades 1 to 2. The belt extends north into Lanesboro (PI. I).

There are three important calcitic marble belts in the township of Pittsfield. One begins 2 miles west of the city, south of Lake Onota, on the William Bruce place, and extends about three-quarters of a mile south, including several abandoned quarries. Granular dolomite crops out west of it. There is another small area of calcite marble between Lakes Pontoosuc and Onota, over 2 miles northnortheast, which may possibly be continuous with this belt. Another begins at the ancient Brodie quarry, a mile south of the "Radium Spring," reappears in minor outcrops south of Smith Brook (localities 89, 90, 91), but chiefly in large outcrops north of Phelps Brook (locality 81). The calcite marble of various sorts, mottled and

$3 \mathrm{About}$ three-fourths of a mile northeast of Barkerville at a road corner there are calcitic boulders or parts of a ledge. If the latter they would signify either the presence of a small outlier of Horizon III in the dolomite or else necessitate the shifting of the dolomite-calcite boundary to make it turn about half a mie north of Barkerville to join the boundary north of locslity 77 , as shown by the dotted line on Piate II. 
white, indicated by the outcrops hereabouts probably covers not less than 1,000 feet square and possibly 1,500 feet square, and it is within a quarter to half a mile of the Boston \& Albany Railroad. It is uncertain whether this marble area is cut off south of Phelps Brook by dolomite or whether it is continuous under the soil and Richmond Pond with that quarried at locality 163 by the Pittsfield lime \& Stone Co. These hypothetical interpretations are indicated in dotted lines on the map. The third belt appears in outcrops northwest of West Pittsfield station and northeast of the Shaker village. It skirts the foot of the Taconic Range northward into Lanesboro and southward into Richmond.

The western Pittsfield calcitic belt above referred to occupies the southeast corner of Hancock Township. A mile northeast of Perry Peak in the Taconic Range the road from Pittsfield to Mount Lebanon crosses a very narrow strip of calcitic limestone 0.9 mile long, as shown on the map. This probably belongs in Horizon IV and is exceptional.

Richmond and Lenox.-The outcrops in Richmond are mostly calcitic, but a mile south-southwest of Careys Corners there is dolomite, and again half a mile southwest of that, indicating the possibility of the area of dolomite shown on the map. Half a mile west of Richmond Summit station dolomitic and calcitic rocks are in contact on the Dobson farm (locality 122). The rock quarried by the Pittsfield Lime \& Stone Co. at locality 113, midway between the station and Careys Corners, is calcite marble. (See p. 24.)

In Lenox calcite marble crops out at the east shore of Laurel Lake (locality 225) and was quarried for flux for the iron furnace a quarter of a mile to the north on the east side of the road. On the Pattison place, a quarter of a mile farther north (locality 226), almost a mile west of Lenox Furnace, there are large outcrops of calcitic limestone. The total width of this rock from the road on the west is about 1,000 feet with dolomite in contact on the east and extending to Lenox Furnace. As shown on the map this calcitic belt probably continues south in two narrow strips, one on the east the other on the west of the schist masses that flank the hillock north of Lee. North of the Pattison place the calcitic belt either ends or is covered with drift. On the west the belt is bounded by dolomite which crops out along the road off and on for a mile.

The dolomitic area of Pittsfield and Dalton forms a belt a mile wide at the south in the Housatonic Valley, joining that of Lenoxdale and Lee.

The calcite marble that has been quarried north and east of the schist of South Mountain in Pittsfield continues southward to Lenox village but sends off a short arm southward toward Lenox Station. It $21200-23-$ Bull. $7+4-2$ 
forms a considerable area east of Yokun Seat, where it was quarried at locality 120. Two miles north-northeast of Lenox and east of the Auchmuty house (locality 233) the calcite marble is in small westward overturned folds and interbedded with semigranular dolomite. The beds are from 2 inches to 2 feet thick, but the calcitic beds are in places thicker. Here are the long disused Hutchinson quarries, which supplied a kiln at the highway half a mile to the east. This calcitic belt is continuous northwest of Lenox with that bordering the schist of West Stockbridge Mountain.

West Stockbridge.-The West Stockbridge valley is about $3 \frac{1}{2}$ miles long with a schist ridge on the west. (Maple Hill) and another on the east (West Stockbridge Mountain). In the northern part of the valley there is a very narrow schist outlier a mile long. The calcitic limestone borders the valley on both sides and also surrounds and underlies the schist outlier. The quarries as shown on the map are in the calcitic belt on either side of the valley, and two of them are close to the west side of the schist outlier. South of the outlier the central part of the ralley for a width of half to three-quarters of a mile is occupied by a mass of dolomitic limestone, which also sends a prong northward on the west between Housatonic River and the outlier and another but longer and wider prong on the east. As the dolomite is older than the schist it is evident that the reason for the exposure of the dolomite is the removal of the calcitic beds that once overlay it; and in like manner the schist outlier is a remnant of the schist mass that once covered the entire limestone of the valley and joined the masses of Maple Hill and West Stockbridge Mountain.

The following details as to this dolomite area were noted: Beginning on the southeast, dolomitic limestone forms the lower 140 feet of the spur on the top of which is the Rockdale calcite marble quarry. About $1 \frac{1}{4}$ miles north of it, and a little north of the Simpson house, is a railroad cut that trends $\mathrm{N} .35^{\circ} \mathrm{W}$. about 125 feet long in dolomite. There are fine exposures of the rock on a prominent knoll on the Curran farm west of the second road fork north of the Rockdale quarry. (See p. 34.) It also constitutes the large knoll in the center of the belt and has been prospected a little west of the road fork. Dolomite underlies the calcite limestone at the Tobey quarry and forms the high cliff north of it and east of the railroad. Other outcrops are shown by symbols on the map.

In the same township south of State line station and the cut in the Taconic Range there is another area of dolomitic limestone which extends to the New York line and is about half a mile wide. Like that in the West Stockbridge valley it appears to project through the calcitic limestone. Although never quarried it has been core drilled

6 See for the folds U. S. Geol. Survey Bull. 521, fig. 11, p. 79, 1912: also Sixteenth Ann. Rept., pt. 1, fig. 70, p. 550, 1896; and for the microscopic descriptions, p. 41 of this bulletin. 
(n) the Jesse Bliss farm by the Atlas Cement Co. of Pennsylvania. (See p. 35.) The calcitic limestone northeast of the Bliss house was once burned for lime in a small way.

In the calcitic belt between Maple Hill and the Taconic Range are the well-known outcrops of calcite marble on the south side of Stockbridge Center Church.

Alford.-Southwest of Stockbridge Center Church there is a narrow strip of dolomitic limestone $1 \frac{1}{2}$ miles long: and along the west foot of Tom Ball Mountain, near the Gross calcite marble quarry, is the north end of a tapering mass of dolomitic limestone which extends at least 20 miles southward into Salisbury, Conn. (Pl. III). The Gross and Mann marble quarries lie in the calcitic belt between this tongue of dolomite and the schist of Tom Ball Mountain. The dolomite immediately under the Mann quarry calcite marble is fine granular, but farther down on the west side of the highway it is a twinned dolomite-that is, a marble-and was quarried for marble. A little more than a mile north of Alford village, on the John Oles farm, in the calcitic area west of this dolomite, is a considerable outcrop of coarsely plicated calcite marble.

Stockbridge, Lee, and Tyringham.-A peculiar set of northwest and north-northwest strikes appears between Lenox and Great Barrington, controlling the courses of some of the rock areas and in places strangely mingled with the normal north-northeast strikes. These abnormal strikes also appear in the center of the dolomite area of the West Stockbridge valley. One of the faults and the strips of various formations north of Lee village, also the southwest side of Rattlesnake Hill in Stockbridge, all have this northwest to northnorthwest trend. ${ }^{7}$ Along the southwest foot of Rattlesnake Hill there seems to be a narrow strip of calcitic limestone indicated by an outcrop due west of the top and east of the road and by others 2 miles south-southwest of them. The stratigraphic position of this strip is not clear.

Beginning at Housatonic River just south of Lee, the dolomite area, in which the Lee Marble Works and the quarries of the Lee Lime Co. and the Standard Lime Co. are situated, extends west $1 \frac{1}{2}$ to 2 miles to a calcitic belt, which north of South Lee is $1 \frac{1}{4}$ miles wide but west of Laurel Lake probably tapers to a third of a mile. Its southern boundary is ill defined. The east-west mass of micaceous and feldspathic calcite rock at South Lee may extend to a line half a mile north of the Housatonic. From the form and relations of the schist mass north of Lenox this calcitic belt is presumably synclinal in structure. The nearest outcrops of calcite marble west of Lee village are on the road to Curtisville at a point $1 \frac{1}{2}$ miles west of the village park and also on the road to Stockbridge 2 miles southwest of that park and a few

iSee Dale, T. N. ,Taconic physiography: U. S. Geol. Survey Bull. $272, \overline{p l} 1$, p. $27,1905$. 
hundred feet south of a crossroads, where it was prospected long ago. If calcitic rock were in serious demand at Lee the half-mile stretch between these two onterops should be explored by drilling. The large outcrops of calcite marble on the estate just east of the Oaklawn Hotel at the west edge of the same calcitic belt show what is likely to be found in other parts of the belt.

West of this calcitic belt is another dolomitic belt through which the underlying metamorphic Cambrian sandstone of Rattlesnake Hill projects and which is thus of anticlinal structure. The fine-grained faintly bluish-white dolomite quarried for the roads and bridges on the Westinghouse (now Vanderbilt) place at locality 191, in Stockbridge, half a mile west of the west end of Laurel Lake, is in this belt, also the similar rock near the two road forks a mile southwest of the top of Rattlesnake Hill (locality 230). This dolomite recurs at the extreme south end of Stockbridge Bowl (locality 216), and west of it at several points, as well as south of Curtisville. The angle of calcitic limestone represented on the map as ending on the east shore of the Bowl is not exposed but was inferred from the presence of a very small outlier of typical Berkshire schist at that part of the shore. As this schist normally overlies the calcitic rock it usually occurs in calcitic areas. The New York, New Haven \& Hartford Railroad between Stockbridge and Glendale cuts dolomite at five points. There is a small building-stone quarry half a mile southwest of Stockbridge station, but the rock is unsuitable for lime. The west and north limits of this dolomitic belt are not well defined for want of outcrops, but it is assumed that the dolomite does not anywhere reach the mass of West Stockbridge and Lenox mountains, which is here and there bordered with outcrops of calcitic rock. Abnormally outliers of Berkshire schist in the valley between Stockbridge village and Monument Mountain overlie the dolomite of Horizon II.

The quarry (locality 219) that furnished the dolomite marble for the east wing of the National Capitol lies a mile north-northeast of Lee Church, in the same dolomite area as the quarries south of Lee but separated from them by the complex of earlier and later rocks forming the hillocks north and east of the village."

The eastern dolomite belt of Lee continues southeastward into the Tyringham valley.

C'anaan, New Lebanon, and Austerlitz.---In general the limestone of New Lebanon, Canaan, and Austerlitz townships, in Columbir County N. Y., is identical with that of Stephentown and Berlin, in Rensselaer County described on page 8 , with which it is continuous. The limestone belt east of the schist mass of the Knob and the Snake Den was examined at localities 157 and 158, near Edwards Park station and in the western belt at locality 159 , at the Boston \& Albany Railroad tunnel, and at localities $151,152,153$, and 154, north of Canaan 
village. $\Lambda t$ locality 157 there is a large outcrop of very fine granular dolomite with pyrite and minute quartz veins. At locality 158 there is a finely laminated light bluish-gray granular calcitic limestone containing beds and lenses of granular dolomite with quartz veinlets. These rocks are described on page 42. At the west end of the tunnel (locality 159) the following section is exposed, beginning at the bottom: Granular calcitic limestone, 15 feet; granular dolomite, 20 feet ; granular calcitic limestone, 4 feet; granular dolomite, 1 foot; brecciated granular dolomite in a cement of calcite, 2 feet and more. At the east mouth of the tunnel the limestone and dolomite are much interbedded, and both are interfolded with the schist of Horizon IV. At locality 151, 1 mile northeast of Canaan station, the rock is a darkgray granular limestone with some quartzose beds. (See p. 42.) At locality 152, a little farther north, on the Bigelow farm, the granular limestone crops out again but with beds of dolomite (specimen 152, b, p. 36) up to 3 feet thick. In places, however, the rock is a dolomitic granular limestone (specimen 152, c). At locality 153, a little north of locality 152, there is a considerable outerop of a rustyweathering thinly stratified quartzose rock (specimen $\mathrm{D}, \mathrm{XL}, 153$, a), which under the microscope proves to be a pyritiferous, slightly dolomitic quartz sandstone. The percentage of dolomite (granular) is not over 25, and among the quartz grains are a few of feldspar (microcline). The oxidation of the pyrite accounts for the rust color and the solution of the dolomite by atmospheric acid accounts for the surface decay. At locality 154, just south of the New Lebanon line, there are large outcrops of bluish-gray granular limestone interbedded with granular dolomite jointed transversely to the bedding of the limestone, but the joints are confined to the dolomite, owing either to the effect of its greater rigidity under strain or else to its greater contraction in solidification. (See fig. 1.) The limestone area southwest of the village of Austerlitz is necessarily similar in character to that of Canaan.

\section{SHEFFIELD AND SANDISFIELD QUADRANGLES.}

[See Pl. III.]

Taconic Range calcitic belt.-The calcitic belt along the east foot of the Taconic Range in Alford and also in West Stockbridge west of Maple Hill and about State Line continues sonthward into the area shown on Plate III.

In the northwestern part of this area this belt makes several sharp zigzags roughly parallel to those in the schist mass of the range. On the southeast slope of Baldwin Hill, in Egremont, the calcitic belt is in contact with a dolomitic belt on the east. In thin section the dolomite is pure, but the calcite rock contains minute beds of dolomite. About a mile farther south-southeast, half a mile north-northwest 
of South Egremont, is the now idle Joyce quarry, where the rock is a finely banded gray and white calcite marble. In the southeast corner of Egremont Township, three-fourths of a mile west of Davis Pond, is a conspicuous knoll of calcite marble (locality 63) rising 100 feet above the meadows. Two miles farther south-southeast, on an 80-foot knoll, is the abandoned Briggs marble quarry. Its coarse calcite marble is in places interbedded with granular dolomite. (See p. 63.) Hereabouts the calcitic and dolomitic belts are interfingered, but for several miles southward the calcitic belt narrows and the boundaries turn from a north-northwest trend to their normal north-northeast trend. There is a considerable outcrop of calcite marble near the Scoville limonite ore bed on the south side of Ball Brook.

Central calcitic belt.- The central calcitic belt may be said to begin in a narrow strip on the west side of Tom Ball Mountain and is continuous with that on the Pittsfield quadrangle in which the Mann and Gross marble quarries are situated. South of the Tom Ball mass of schist this calcitic area is cut off by dolomite, probably in consequence of the northerly pitch of the folds, aside from any effect on the east of the hypothetical fault, but it reappears 5 miles south-southeast, at the Goodale quarry. This quarry furnished marble for Girard College, Philadelphia, but is now worked for lime by the Berkshire Hills Lime Co. How far north of this point the calcitic belt extends is uncertain. Outcrops of dolomite are sufficiently close along the road from South Egremont to Great Barrington to cut off the calcitic belt effectually, but between the Goodale quarry and that road there is over a square mile without outcrops, which may be underlain by either the calcitic or the dolomitic limestone. A mile southsoutheast of the Goodale quarry is the abandoned Upson quarry, and half a mile southeast of that, on the E. S. Hoskins farm, are a number of outcrops of calcite marble, one of which (locality 97) is reported to have supplied material for part of the courthouse at Pittsfield.

From Sheffield Plain southward the calcitic belt rapidly widens to 3 miles and is dotted over, as mapped by Professors Hobbs and Barrell, with schist outliers, the largest of which, on Miles and Toms mountains in Connecticut, covers from 2 to 3 square miles. All these schist masses are evidently the remnants of a continuous mass that occupied the center of the valley and was originally connected with the Taconic Range.

At Ashley Falls the east boundary of the central calcitic belt meets the longitudinal fault prognosticated by Professor Barrell, which separates this belt from the dolomite belt east of it as far as the south limit of the area.

Two miles south-southwest of Sheffield are the abandoned quarries of the Massachusetts Lime Co. described on page 46. Three-fourths 
of a mile southwest of them a small dolomite area projects through the calcitic limestone. Calcite marble is well exposed south of the road on both sides of the long schist outlier east of Schenob Brook. Midway between Chapinville and Babes Hill on the north side of the road are large outcrops of calcitic limestone, and northeast of the northeast shore of Twin Lakes calcite marble crops out along the road and borders the schist mass of Toms Mountain on the west. The same marble crops out along the southeast foot of that mountain, near a sharp railroad curve where the New England Lime Co. made an opening years ago, but the locality is less favorable than those on the . northwest and northeast sides of 'Twin Lakes. In general calcite marble is to be expected around the edges of the schist outliers and along the base of the schist ridges except where the maps show that the dolomite has taken the place of the calcitic rock.

Western dolomitic belt.- The western dolomitic belt is the southern continuation of the tapering belt in Alford west of Tom Ball Mountain, in the Pittsfield quadrangle, described on page 13. A mile north of Alford village and west of the east road there are large outcrops of granular dolomite. Large outcrops also occur in the southwest corner of Great Barrington Township a mile east of Egremont Plain and half a mile west of Green River, also at a trolley cut northeast of the Charles Reed house and again nearly half a mile east of it. (See description on p. 33.) About $1 \frac{1}{2}$ miles west-northwest of Sheffield village is the abandoned Dresser quarry (locality 17). The dolomite is very fine grained and semigranular. A similar dolomite crops out in Chapinville in the same belt $5 \frac{1}{2}$ miles to the south. This belt attains a width of $1 \frac{1}{2}$ miles in Sheffield but tapers to half a mile at the south. North of South Egremont it merges in the eastern dolomite belt.

Central dolomitic belt.-The central dolomitic belt, which begins about Long Pond in Great Barrington and merges in the western dolomitic belt, in the eastern part of that township, extends southward through Sheffield village and Ashley Falls into North Canaan Township in Connecticut, passing between Canaan Mountain on the east and the central calcitic belt on the west. A little southeast of the Goodale quarry in Sheffield (locality 61) the dolomite is very fine grained and twinned-that is, it becomes a marble. A mile south-southeast, at the abandoned Goodsell quarry, it is similar but a trifle coarser. At a small opening at the south end of Mill Pond in Sheffield the dolomite is also a fine marble. At the Ashley Falls quarry white dolomite marble, 30 feet thick, overlies 50 feet of light bluish-gray marble.

Eastern dolomitic belt.-The dolomite of Stockbridge passes southward along Muddy Brook valley, on the east side of Monument Mountain and Warner Mountain, sends an arm eastward to Lake Garfield 
near Monterey village, and passes southward along the valley of Konkapot River into North Canaan, Conn., where it merges in the central dolomite belt. At locality 131, 3 miles east of Great Barrington, the rock is a twinned dolomite of texture grade 3. At locality 133, in New Marlboro, southwest of Lake Buel, near an old limekiln, there is a cream-colored dolomite marble of texture grade 5 (coarse). At locality 129, three-quarters of a mile northwest of Monterey village, there is a bluish-white granular dolomite of porphyroid texture, described on page 36 and shown in figure 9. It contains hard lenses - consisting of tremolite, quartz, muscovite, pyrite, and feldspar (microcline), with a little dolomite. At locality 139, half a mile north-northeast of Konkapot, is a white and bluish-gray dolomite marble of irregular texture (grades 5 to 6 ), containing quartz and tremolite with nodules of tremolite, quartz, pyrite, phlogopite, and dolomite. At the Cathole quarry, three-quarters of a mile southeast of Konkapot, one of several openings on the side of Benton Hill, the rock is a dolomite marble (specimen $\mathrm{D}, \mathrm{XL}, 140$, a) banded in various shades of bluish-gray and containing quartz, tremolite, pyrite, and phlogopite. Some fine dark-gray bands are pyritiferous; some light-brownish ones contain phlogopite and pyrite.

In North Canaan, on the north foot of Rattlesnake Hill, there are two disused quarries of dolomite marble for lime. The active quarries of the New England Lime Co. are on the south side of the same hill, and that of the Connecticut Lime Co. is a mile southeast of Canaan village. There is a disused dolomite marble (lime) quarry at the north foot of Canaan Mountain, and the quarries of the New England Lime Co. and the Allyndale Co., the latter disused, are on the southeast side of Rattlesnake Hill. In view of the proximity of these dolomites of North Canaan to the areas of the Dalton formation of Horizon I (see Pl. III), mapped by Prof. Barrell, these dolomite marbles may belong lower down in Horizon II than those immediately under Horizon III. The stratigraphic position of the quartzite areas marked $€ O s q$ seems to be variable.

From investigations along the west foot of Canaan Mountain in the Cornwall quadrangle, just south of the area shown on Plate III, there appears to be a strip of more or less impure calcitic limestone separating the schist of that mountain from the dolomite, although no outcrops of the calcitic rock were found on its north side. Calcitic limestone may for this reason form a narrow border about the schist outlier (Church Hill) just south of Canaan village and may also border the schist mass of June Mountain on the south near Sheffield village.

West foot of Taconic Range in Hillsdale, N. Y.-As shown on Plate II the calcitic limestone comes up from under the schist mass of the Taconic Range forming a strip as much as two-fifths of a mile wide 
between the schist and the dolomite on the west. At locality 148, close to the schist, the rock is a bluish-gray graphitic calcite marble of texture grades 1 to 2 . At locality 146, nearly half a mile farther west and close to the dolomite, there is a quartzose pyritiferous semigranular calcitic limestone, at least 50 feet thick, with small and minute lenses of granular dolomite. This is related to the limestone of Canaan, Stephentown, and Berlin, N. Y., described on page 42. The Hillsdale calcitic belt thus seems to consist in part of marble and in part of limestone.

At localities 144, 143, and 147 the granular dolomite of Horizon II is well exposed. That of locality 143 is described on page 36 as typical of this section. At locality 145 the dolomite is exceedingly quartzose, consisting of minute beds mostly of quartz with some feldspar grains alternating with little beds mostly of dolomite. The weathered face shows current bedding, the more quartzose beds projecting.

\section{CLOVE QUADRANGLE.}

[Sec Pl. IV.]

General features.--The Clove quadrangle lies mostly in Dutchess County, N. Y., and Dover Plains, near its north edge, is roughly about 25 miles south-southwest of Canaan, Conn., near the south edge of the Sheffield quadrangle. The geologic mapping was confined to the east half of the quadrangle-- to the valley of Swamp River and its tributaries and that of Tenmile River from a point 1 mile north of Dover Plains southward to a point near the Connecticut line. ${ }^{8}$

The lime belt is bordered on the west by a ridge of Berkshire schist (Horizon IV) and on the east by a certain quartzite of Cambrian age (Horizon I) and from Webatuck south to a point near Pawling village apparently again by Berkshire schist.

There is a conspicuous inlier of biotite granitoid gneiss in the northern part of Pawling, Corbin Hill, about 2 miles long, which one would expect to be mantled by Cambrian beds. But the interval between this gneiss and the calcitic beds of Horizon III, both at the southwest and the northwest, is too small for the entire thickness of the quartzite of Horizon I and the dolomite of Horizon II; and on the east side the nearest outcrops are dolomite and half a mile away. In view of these uncertainties an area about this gneiss mass has been left on the map without geologic coloring.

Dolomitic belt.-At the north limit of the quadrangle the dolomite is 1.8 miles wide and all granular. It appears on the conspicuous Fox Hill and on the high ground east of it and continues northward in the township of Amenia (Millbrook quadrangle) in numerous outcrops 3 miles to South Amenia, where these investigations stopped.

\footnotetext{
'The writer has had access to a copy of the Clove to ooyraphic map upon which some incomplete reconnaissance entries were mace by Prof. W. H. Hobbs some yeurs ago, during the geologic mapping of western Connecticut. These entries indieated localities of gneiss, quartzite, limestone, and schist.
} 
At locality 174, $1 \frac{1}{2}$ miles southeast of Dover Plains station, is the quarry of the Kelley Island Lime \& Transport Co. of Cleveland, Ohio. The rock is a faintly bluish-white semigranular dolomite as shown in figure 3 and of an average grain diameter of 0.136 millimeter and of texture grade 3 . At localities 175 and 272 are disused quarries of the same company. Between localities 174 and 272 are many outcrops of white dolomite weathering into snowlike sand. Some of the beds abound in tremolite crystals, and many of these, instead of consisting of simple rhombic prisms like those in the dolomite of Lee, Mass., have largely developed orthopinacoidal planes and thus a flattish form. In this same area the dolomite includes a few small beds of schistose and quartzitic rock. At locality 275 gray dolomite was once quarried for headstones. At locality 209 on the quarry railroad a small cut shows a fine white twinned dolomite with graphitic streaks along the bedding but in places also nodules of the dark dolomite as much as 6 inches in diameter. One little graphitic bed is clearly faulted. These anomalies are attributed to rock flowage under great pressure.

At locality 208, three-quarters of a mile southeast of Dover Plains, on the west side of a long hillock, is another quarry of the same lime company. The rock, a fine twinned dolomite, disintegrates into powder in the kiln, and the quarry has therefore been abandoned. An analysis and a description of this rock are given on page 31 .

Farther south the dolomite crops out on both sides of the valley. A steep hill about three-quarters of a mile north of Dover Furnace station rises 200 feet above Swamp River. It is made up mostly of very hard slaty and rusty beds consisting in descending order of quartz, mica (phlogopite), granular dolomite, feldspar (microcline), and pyrite oxidized to limonite. This mass includes a few beds of grayish granular dolomite with a little quartz and mica. There are large dolomite outcrops south-southeast of Dover Furnace station and an abandoned dolomite marble quarry $1 \frac{1}{2}$ miles east-southeast of it.

Between Dover Furnace and Wingdale stations the dolomite of Horizon II widens to $2 \frac{1}{2}$ miles, corresponding to the recess in the quartzite and gneiss ridge on the east. In this recess between Ellis Pond and Webatuck are many outcrops of dolomite, some of it granular, some twinned. In about the center of this area (locality 176) is the quarry of the South Dover Marble Co., described with its marble on page 64 .

South of Wingdale station the dolomite belt narrows to 2 miles but includes in its western half the Berkshire schist outlier of Mount Waldo, a strip of Horizon III east of it, and in Pawling the granitoid gneiss inlier of Corbin Hill. 
The same stratigraphic irregularity noted in Berkshire County (p. 3) recurs in Dover and Pawling, for the dolomite of Horizon II is evidently in contact with the schist (Horizon IV) on the west for several miles south of Dover Plains and again for several miles west of Mount Waldo, but from Dover Furnace for about 2 miles south the calcitic Horizon III has its normal place. If the schist mass south of Wingdale station is the Berkshire schist, as appears probable from the Connecticut State geologic map, then the dolomite there has also taken the place of Horizon III and the valley is anticlinal in structure; but north of Dover Furnace, as the ridge on the east is of Horizon $I$ and earlier, the structure of the valley presumably consists of a syncline on the east, another on the west, and an anticline between.

Calcitic areas.-A mile south-southwest of Dover Plains (locality 177) a cutting near a bend in the highway shows about 50 feet of impure calcitic beds striking north and consisting of minute alternating beds of calcite marble with quartz, pyrite, and micas and of semigranular dolomite with the same minerals. Higher on the ridge and overlying these beds is white calcite marble, possibly 100 feet thick, but at the little saddle on the east the fine granular dolomite appears containing some pyrite, quartz, feldspar, and muscovite. The caloitic series here presumably lies in a westward-overturned syncline of dolomite. The extent of these marble beds from north to south can be determined only by east and west trenching or by drilling. - This deposit is on the west side of the ridge on the east side of which is the abandoned dolomite quarry (locality 208) of the Kelley Island Lime \& Transport Co. (See p. 20.)

The relation of the dolomite outcrops at localities 182 and 183 to the schist at localities 180 and 181, taken in connection with the probable synclinal structure at localities 177 and 178 , indicates that for several miles south of Dover Plains the dolomite adjoins the schist.

Due north of Dover Plains 1.1 miles, in the township of Amenia (Millbrook quadrangle), on the Smoot place, there are outcrops of impure calcite marble in all about 300 feet wide. This is 200 feet east of the schist, but it has schist on its east side. The general strike of the marble is N. $40^{\circ} \mathrm{E}$. and of the schist at the road N. $20^{\circ} \mathrm{E}$. The structure is complex. The marble may form an anticline from which the overlying schist has been Iargely eroded. Although without economic value, this calcite marble shows the possibility of the occurrence of the calcitic series in its normal relation to the schist on the west side of the valley.

Half a mile south of Dover Furnace station, on the railroad (locality 228), the calcite marble crops out in contact with the dolo- 
mite on the east, which appears in many outcrops to the south and southeast, already referred to (p. 22.) Half a mile southwest of locality 228 , at locality 225 , the calcite marble is in contact with the schist of the east ridge. Again two-fifths of a mile west-northwest of locality 225 the marble crops out in a brook flowing from the vicinity of the old iron furnace. The outcrops at localities 224. 225, and 228 together indicate a belt of calcite marble under the swamp at least a mile wide and in contact with the schist on the west. Marshes cover the calcitic belt south for a mile to a conspicuous group of knolls rising as much as 100 feet above the river and $1 \frac{1}{2}$ miles north-northwest of Wingdale station, where it reappears. The granular dolomite forms the eastern knoll and crops out at the railroad on the east and at the east foot of the next knoll south (locality 198), but the calcite marble occupies a stretch of two-fifths of a mile west of the dolomite. At locality 195 there is a coarse white or gray banded white marble in which are some ancient drill holes. At locality 197 a mottled gray marble was once prospected. At locality 199 , farther south, near an abandoned house, there is a bluish-gray marble of texture grades 5 to 6 . These beds reappear on the next knoll a mile south and are finely exposed in the pastures. On the west is a small schist outlier, but the marble beds crop out on its north and west sides and again west of a smaller schist outlier at the brook. The calcitic area indicated by the outcrops on the knoll east of the larger schist outlier is not less than 1,550 feet square and includes a variety of marbles, the economic value of which for the lime industry can be determined only by trenching across the beds and sampling and testing.

A little south of the road running west from Wingdale station the calcitic area stops, as shown on the map, but it reappears south of the road running west from the new State prison, first at locality 215 , where a banded gray marble has been prospected, and next on a knoll half a mile south of that road on the Frederick Coleman farm (locality 218). The calcite marble area here is from 1,000 to 1,500 feet wide and continues south for three-fourths of a mile to the next road from the east. Exceptionally some of these beds contain a little tremolite, which is usually confined to the dolomite.

The calcite marbles on the several knolls west of South Dorer and Wingdale embrace so many rariations in texture, composition, and shade that it would be misleading to describe any one of them as typical of the series.

Although the dolomite west of Mount Waldo is in contact with the schist, there is a strip of calcite marble on the northwest side of that mountain close to the schist. Between the north end of Mount Waldo and the State prison the road crosses a small lens of calcite marble 
(locality 213). It is cut off by dolomite a quarter of a mile north and half a mile to the south at locality 244 . The thickness exposed at locality 213 is 100 feet. The marble continues south for several hundred feet, but its total length can not be prognosticated.

There is still another small calcitic area near Webatuck, on both sides of Tenmile River, about $1 \frac{1}{2}$ to 2 miles east-northeast of Wingdale station. The best outcrop is at locality 250 , at the river, on the A. P. Bedell property. The beds are about 500 feet wide, strike N. $20^{\circ} \mathrm{E}$, and may be 300 feet thick. Their northward extent seems limited, economically, for there is a drift knoll along the strike, and the dolomite crops out at the south foot of the next knoll to the north. At the other outcrops (locality 248) the calcitic beds also measure about 500 feet in width, but much of the rock is micaceous and quartzose.

The most southerly outcrop in the large calcitic area in Dover is at locality 233, a little north of the Dover-Pawling line and northwest of the north end of the granitoid gneiss mass of Corbin Hill. West of that gneiss is a wide drift area, but at locality 238 in Pawling the calcitic series reappears in very pyritiferous and quartzose beds about 150 feet in width. On the map these two outcrops have been connected by a hypothetical belt.

Farther south the Mount Tom schist mass sends a spur northward, which appears to end on the east side of Green Mountain Lake. The calcite marble reappears on the east slope of Mount Tom, where it underlies the schist on the 820-foot level and continues down the slope to the 620-foot level, where it is underlain by the dolomite. The width of the marble here is 1,000 feet from east to west: it narrows northward to $500 \mathrm{feet}$, and its total thickness is 150 to 175 feet. On the east face of the mountain the strike is normal and the marble forms a shoulder north of which there is a sharp bend in the strike to due east. At locality 260 large outcrops of the marble strike N. $20^{\circ}$ E. The calcitic series continues north-northeastward in a strip a mile in length but of most irregular outline, projecting, in consequence of erosion, through the schist sur. There is also a small marble outlier on the northeast foot of Mount Tom surrounded by dolomite. The calcite marble beds on Mount Tom, like those in Dover, vary in texture, composition, and shade. As they are only half a mile from the New York Central Railroad, although 160 to 360 feet above it, they may at some time prove of economic importance.

\section{THE CALCITIC LIMESTONES.}

A pure calcite $\left(\mathrm{CaCO}_{3}\right.$, lime carbonate) is one of the chief minerals needed in the manufacture of lime, but there are regions where it does not occur in large quantities without considerable admixture of 
other minerals. 'This is the case in western Massachusetts. In describing the calcitic limestones of this belt they will be taken up in the following order: First, the varieties now quarried that are considered specially fitted for the production of "finishing lime"; second, somewhat inferior ones; third, those discarded either because of their content of objectionable minerals or because their texture makes them unfit for burning in upright kilns or because they hydrate on exposure soon after burning.

\section{VARIETIES USED FOR FINISHING LIME.}

Whitish.-Hoosac Valley Lime Co.'s quarry, west of Zylonite, Adams; specimen D, XXXIX, 243, a. Bluish-white calcite marble with some light-grayish streaks and clouds due to a slight amount of graphite. Consists of twinned calcite grains 0.11 to 1.85 millimeters in diameter, estimated average 0.4 millimeter, grade 6 (extra coarse A). ${ }^{9}$

The general quality and texture of the best stone quarried by the New England Lime Co. at its Renfrew quarry, Adams, are identical with the above.

Pittsfield Lime \& Stone Co.'s quarry, Richmond; specimen D, XXXIX, 163, a. Extremely pale grayish (not bluish) calcite marble, semitranslucent. Consists of twinned calcite grains 0.075 to 1.1 millimeters in diameter, estimated average 0.246 millimeter; grade 5 (coarse). Some grain elongation. Contains streaks about 1 millimeter wide of grains 0.001 to 0.047 millimeter in diameter, probably dolomite; quartz grains (some of quartzite ?), very little muscovite, some pyrite.

Grayish, more or less graphitic.-New England Lime Co.'s quarry, West Stockbridge; specimen D, XXXIX, 123, a. Plicated beds, 0.25 to 1 inch thick, white alternating with medium bluish-gray calcite marble. Consists of twinned grains of calcite, 0.05 to 0.75 millimeter in diameter, estimated average 0.16 millimeter; grade 4 (medium). Some grain elongation. Contains a little quartz, rare grains of feldspar, a little pyrite, graphite in very minute grains, no mica.

Tobey Lime quarry, West Stockbridge; specimens D, XXXIX, 125, a, b. Bluishwhite calcite marble with clouds and little beds of medium to dark gray. Consists of twinned calcite. Grain diameter 0.05 to 0.75 millimeter, estimated average 0.16 millimeter; grade 4 (medium). Contains very little quartz or pyrite, some graphite in very minute grains, no mica. .

The best stone at the C. L. Miller quarries is identical with the two last.

Berkshire, Hills Lime Co.'s Goodale quarry, Sheffeld; specimen D, XXXIX, 60 , d. Faintly bluish-white calcite marble with medium to dark-gray beds up to 0.2 inch thick. Consists of twinned calcite. Grain diameter 0.185 to 1.28 millimeters, estimated average 0.37 millimeter; grade 5 to 6 . Contains some quartz and feldspar, a little muscovite, and minute pyrite.

Cheshire Lime Co.'s Dean quarry, Cheshire; specimen D, XXXIX, 259, a. Bluish medium-gray calcite marble. Consists of twinned calcite. Grain diameter 0.11 to 1.1 millimeters, estimated averaye 0.27 millimeter; grade 5 (coarse). Contains extremely little pyrite, some gxaphite, no quartz, mica, or feldspar.

Farnam Cheshire Lime Co.'s quarry, Cheshire; specimen D, XXXIX, 254, a. Dark-gray calcite marble. Consists of twinned calcite. Grain diameter 0.074 to 0.925 millimeter, estimated average 0.21 millimeter; grade 5 (coarse). Contains very little quartz, no mica or pyrite, some graphite.

s See table of grades of marble texture, p. 63. 


\section{VARIETIES REGARDED AS NOT MAKING THE BEST FINISHING LIME.}

Berkshire Hills Lime Co.'s Goodale quarry, Sheffield, specimen D, XXXIX, 60, a. Dark-gray calcite marble. Consists of twinned calcite. Grain diameter 0.11 to 1.285 millimeters, estimated average 0.3 millimeter; grade 5 (coarse). It contains areas up to 1 millimeter wide of grains that are mostly not twinned and probably dolomite, 0.037 to 0.185 millimeter across, with some quartz, very little muscovite and pyrite. Used for "common lime."

Hoosac Valley Lime Co.'s quarry near Zylonite, Adams; specimen D, XXXIX, 243, c. Light greenish-gray twinued calcite. Estimated average grain diameter 0.43 millimeter; grades 5 to 6 . Contains much quartz, some pyrite, and a little muscovite.

New England Lime Co.'s quarry, West Stockbridge: specimen D, XXXIX, 123, f. Light bluish-gray calcite marble. Consists of twinned calcite. Grain diameter 0.05 to 1 millimeter, estimated average 0.21 millimeter; grade 4 (medium). The grains are uneven and elongated. Contains much quartz, some pyrite, very little muscovite, rare grains of feldspar.

The same company's quarry at Renfrew, Adams; specimen D, XXXIX, 242, a. Faintly bluish-white calcite marble with beds one-fourth to one-half inch thick of dark gray. Consists of twinned calcite. Grain diameter 0.185 to 1.1 millimeters, estimated average 0.337 millimeter; grade 6 (extra coarse). The dark beds contain streaks. of dolomite grains 0.037 to 11 millimeters across, some pyrite, and graphite. Both kinds of beds contain very little quartz and muscovite.

VARIETIES DISCARDED ON ACCOUNT OF ACCESSORY MINERALS.

Quartzose and micaceous.Hoosac Valley Lime Co.'s .quarry near Zylonite, Adams; specimen D, XXXIX, 243, g. Very light bluish-gray calcite marble. Consists of twinned calcite. Grain diameter 0.11 to 1.285 millimeters, estimated average 0.3 millimeter;

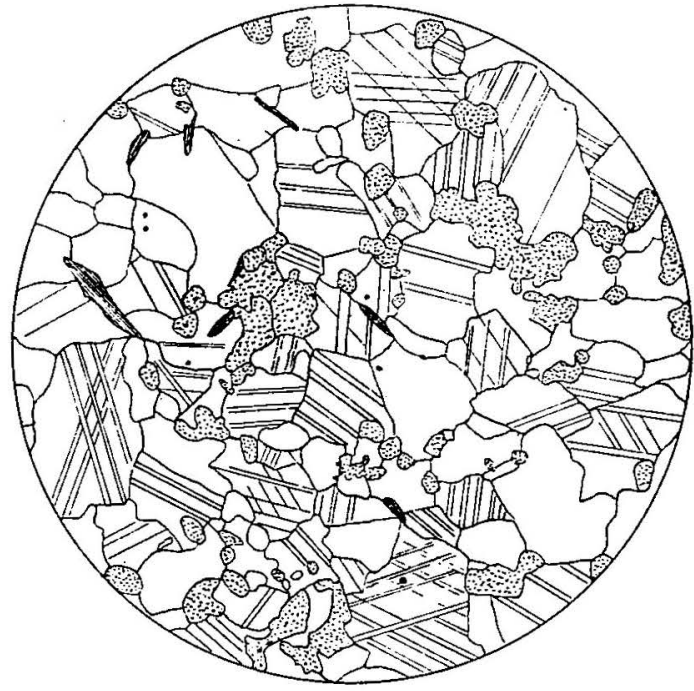

FIGURE 2.-Thin section of quartzose and micaceous twinned cal cite rock from Hoosac Valley Lxime Co.'s quarry, Adams, Mass. Enlarged 19.6 diamcters. Dotted grains are quartz, shaded grains muscovite (white mica), black grains pyrite. Discarded in selecting stone for burning. grade 5 (coarse). Contains much quartz, little muscovite, minute and sparse pyrite. A geometric analysis of this rock by means of the microdrawing (fig. 2) yields these percentages: Calcite, 87.3 ; quartz, 12 ; mica, 0.7 . The effect of quartz upon finishing lime would be equivalent to an admixture of fine sand.

Pyritiferous,-New England Lime Co.'s Renfrew quarry, Adams; specimen D, XXXIX, 242, c. Pale-brownish calcite marble. Consists of twinned calcite. Texture, grade about 5 (coarse). Contains rather evenly disseminated minute pyrite, some quartz, and a little muscovite. The pyrite has become oxidized and the calcite thus stained with limonite. 
Same quarry, specimen D, XXXIX, 242, d. Coarse white calcite marble, with a vein up to an inch thick along the bedding, consisting of iridescent crystallized pyrite with solid grayish crystallized dolomite coated with films of apple-green talc and with vein quartz on one or both sides. Pyrite is probably the worst of the accessory minerals, as under high heat it forms black spherules as described on page 30 and shown in Plate VIII, $B$.

Quartzose and pyritiferous.-Massachusetts Lime Co.'s abandoned quarry, Sheffield; specimen $\mathrm{D}, \mathrm{XXXIX}, 48$, b. Coarse whitish calcite marble with grains of quartz and feldspar and much pyrite. Such a rock after passing through the kiln would not only have the black spherules but also grains of sand and glass.

Dolomitic, quarizose, and micaceous.-The purely dolomitic beds are discarded in the selection of stone for finishing lime. Some of these dolomites are also quartzose. Thus specimen D, XXXIX, 123, i, from the New England Lime Co.'s quarry at West Stockbridge, is a grayish granular dolomite, of grains, mostly not twinned, 0.025 to 0.175 millimeter in diameter, estimated average 0.05 millimeter, grade 1 , and some twinned grains ( 0.25 to 0.5 millimeter) in groups. It contains evenly disseminated fine quartz, some muscovite and pyrite, besides graphite.

A similar rock (specimen D, XXXIX, 48, h) from the Massachusetts Lime Co.'s quarry in Sheffeld, is a hard dark-gray dolomite, mostly of twinned grains, of grades 1 to 2, contains much evenly disseminated quartz, a pale-brownish mica (phlogopite) besides muscovite, pyrite, and graphite.

Specimen D, XXXIX, 60, b, from the Berkshire Hills Lime Co.'s Goodale quarry in Sheffield, is a buff-grayish granular to semigranular dolomite with somewhat fewer twinned than not twinned grains 0.025 to 0.175 millimeter in diameter, estimated average 0.05 millimeter; grade 0.1 . It contains many evenly disseminated minute scales of a pale-brown mica, (phlogopite), some pyrite, and small veins of quartz and dolomite.

Specimen D, XXXIX, 60, c, from the same quarry, is a medium-gray granular dolomite with few twinned grains, diameter 0.025 to 0.225 millimeter, estimated average 0.06 millimeter; grade 1 . It contains quartz in small veins, also in very minute evenly disseminated grains, some phlogopite, and much pyrite in minute grains.

Specimen D, XXXIX, 124, d, from the C. L. Miller quarry, West Stockbridge, is a light bluish-gray granular dolomite with sericite films. It consists of untwinned grains of dolomite 0.02 to 0.1 millimeter in diameter, estimated average 0.035 millimeter; grade 0.1. It contains many evenly disseminated muscovite scales, also sparse grains of clastic quartz and lenses of vein quartz with inclusion of dolomite and muscovite. The section shows a band of sericite with larger dolomite grains.

Dolomitic, micaceous, and pyritiferous.--Specimen D, XXXIX, 243, e, from the Hoosac Valley Lime Co.'s quarry, Adams, consists to the extent of two-thirds or three-fourths of twinned calcite of grade 4 . These grains are crowded with exceedingly minute darkish specks and under crossed nicols show minute light specks. The rest of the rock is mostly twinned dolomite of grade 1 . Fine muscovite and pyrite abound; there are a few grains of quartz and rarely of feldspar.

Dolomitic and graphitic.- Some beds contain enough graphite to darken the lime somewhat. This is probably due to the usual slight amount of ferruginous residue from burned graphite.

Specimen D, XXXIX, 124, c, from the C. L. Miller quarry, West Stockbridge, is a very dark bluish-gray ("black") dolomite with some shiny graphitic planes, also a vein of clear quartz and calcite. It consists very largely of untwinned grains of dolomite 0.01 to 0.1 millimeter in diameter, estimated average 0.025 millimeter; grade 0.1 (extra fine A). It contains some groups or streaks of twinned grains up to 0.62 millimeter in diameter which are calcite. Much graphite throughout in very fine particles; a few quartz grains; very little muscovite. 
U. S. GEOLOGICAL SURVEY

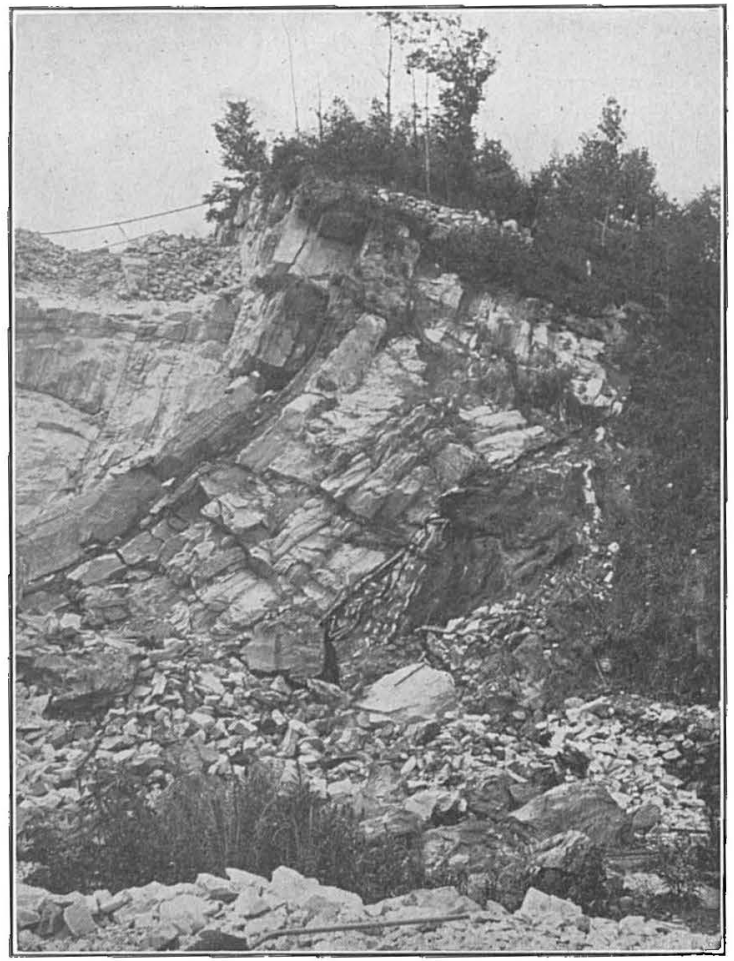

A. WESTERN PART OF WEST OPENING, MILLER UUARRY, WEST STOCKBRIDGE, MASS.

Looking south-southwest. Shows contact of calcitic beds with underlying plicated gruphitic, biotitic schist with quartz
ledses and laminae, apparently unconformable to the limelenses and laminae, apparently unconformable
stone. Sled te ou rock near schist 30 inches long.
BULLETIY 744 PLATE $Y$

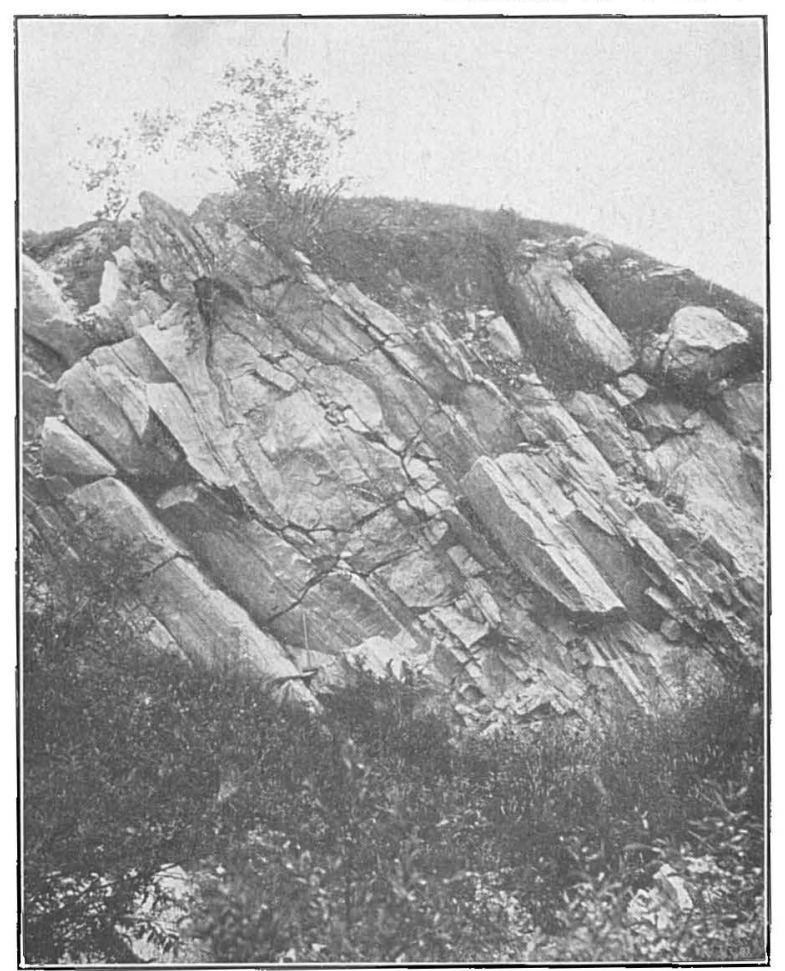

B. EASTWARD-INCLINED COMPRESSED ANTICLINE WITH GRANULAR DOLOMITE IN THE CENTER AND CALCITE MARBLE ON BOTH SIDES, SOUTH WALL OF TRUESDELL QUARRY (NORTH), WEST STOCK BRIDGE, MASS.

Sledge 30 inches long. 


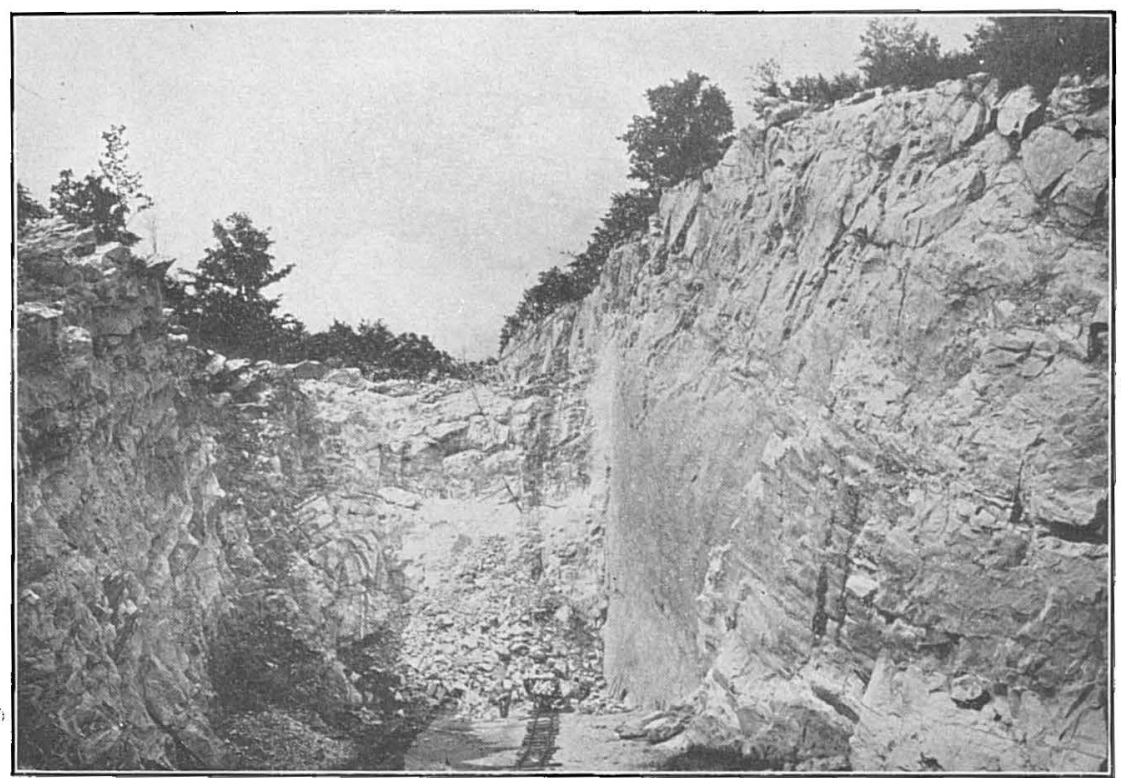

A. EAST OPENING, MILlER QUARRY, WEST STOCKBridge, MASS.

Looking southwest. Shows at the left the apex of an anticline and on the ritht the east limb of the central syncline shown in figure 16 . Excavation is proceeding along the strike. The rock is caleite limestone with some interbedded dolomite.

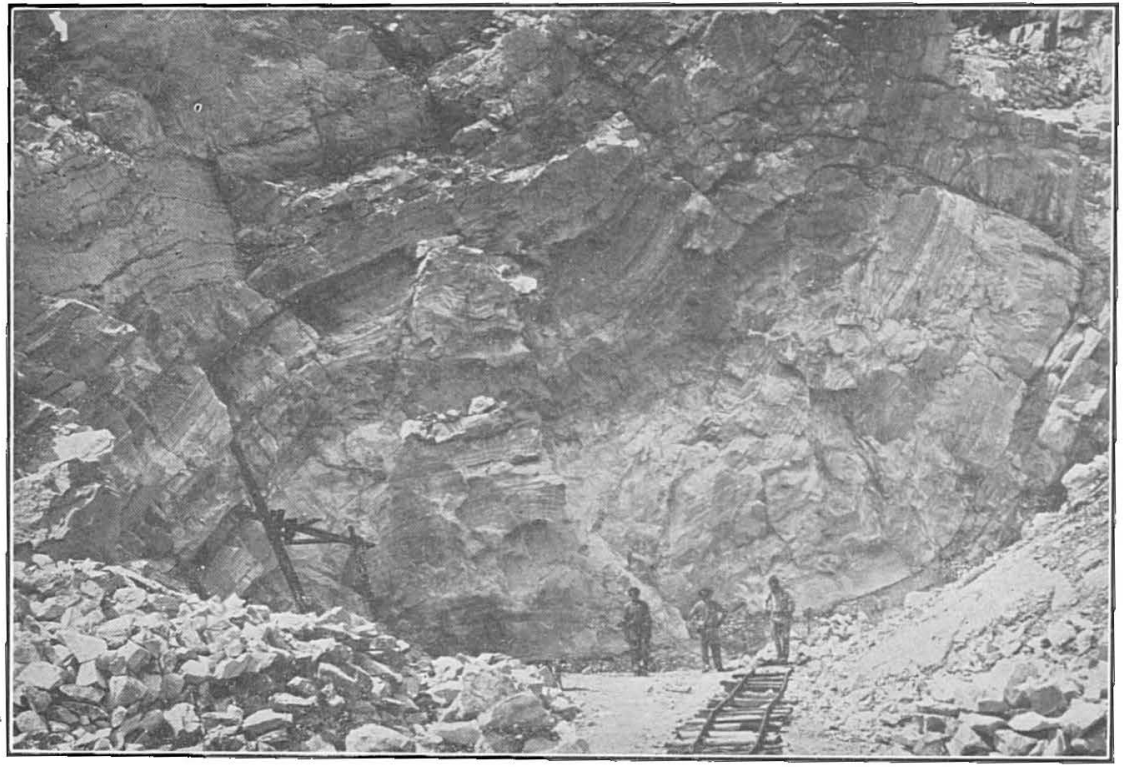

B. EASTERN PART OF WEST OPENING, MILLER (QUARRY, WEST STOCKBRIDGE, MASS.

In west limb of central syncline. The beds vary greally in composition and have to be carefully sorted for burning. For details see figure 16 . 


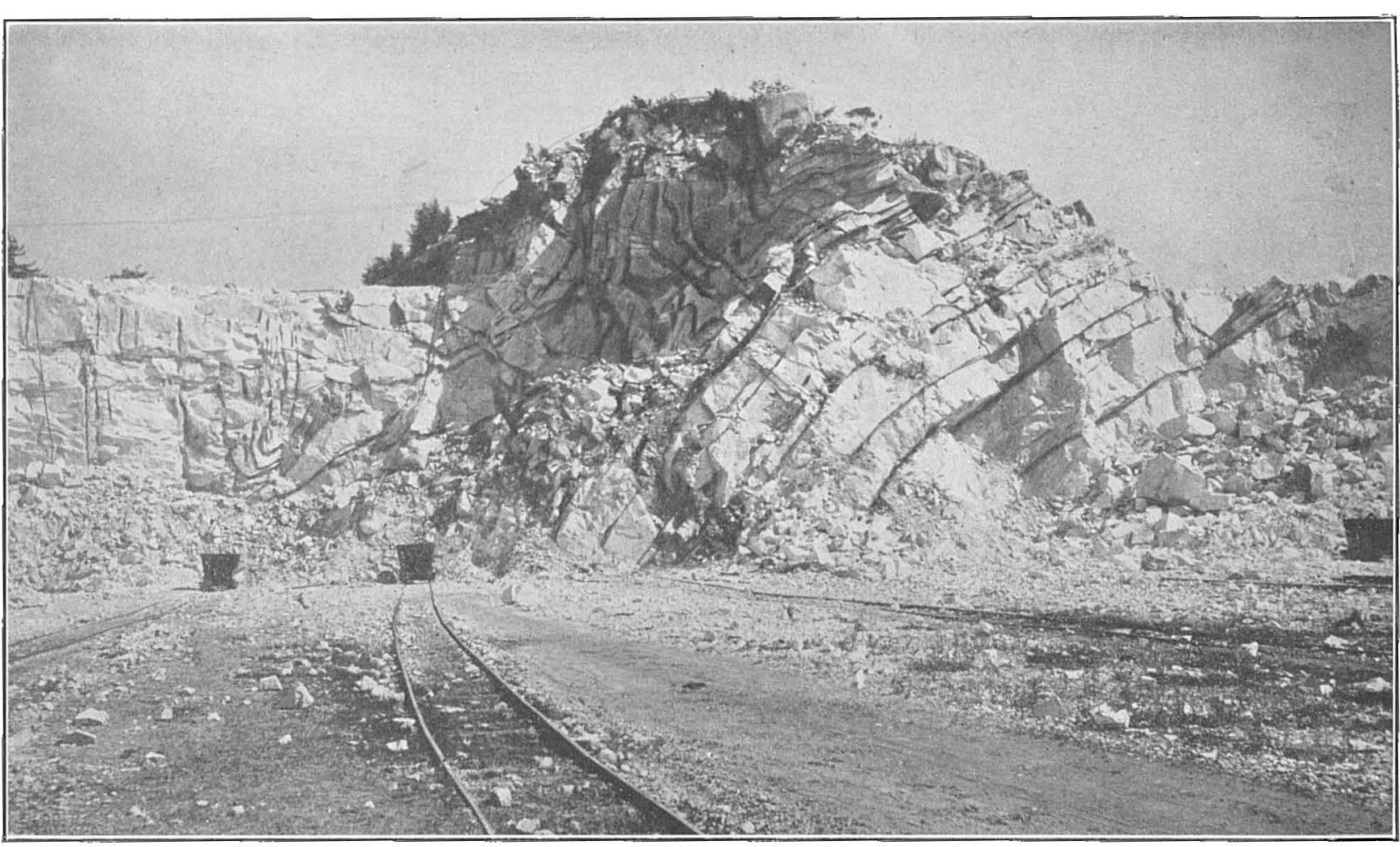

CENTRAL FOLDS ON SOUTH WALL OF LEE LIME CO.'S QUARRY, LET, MASS,

There is a well-marked syneline on the enst and the heds on the west seem to be bending below to form another syneline. If this is correct the centrat hump consists of two minor anticlines and a small syucline between them. The three small graphitic beds appear among the 


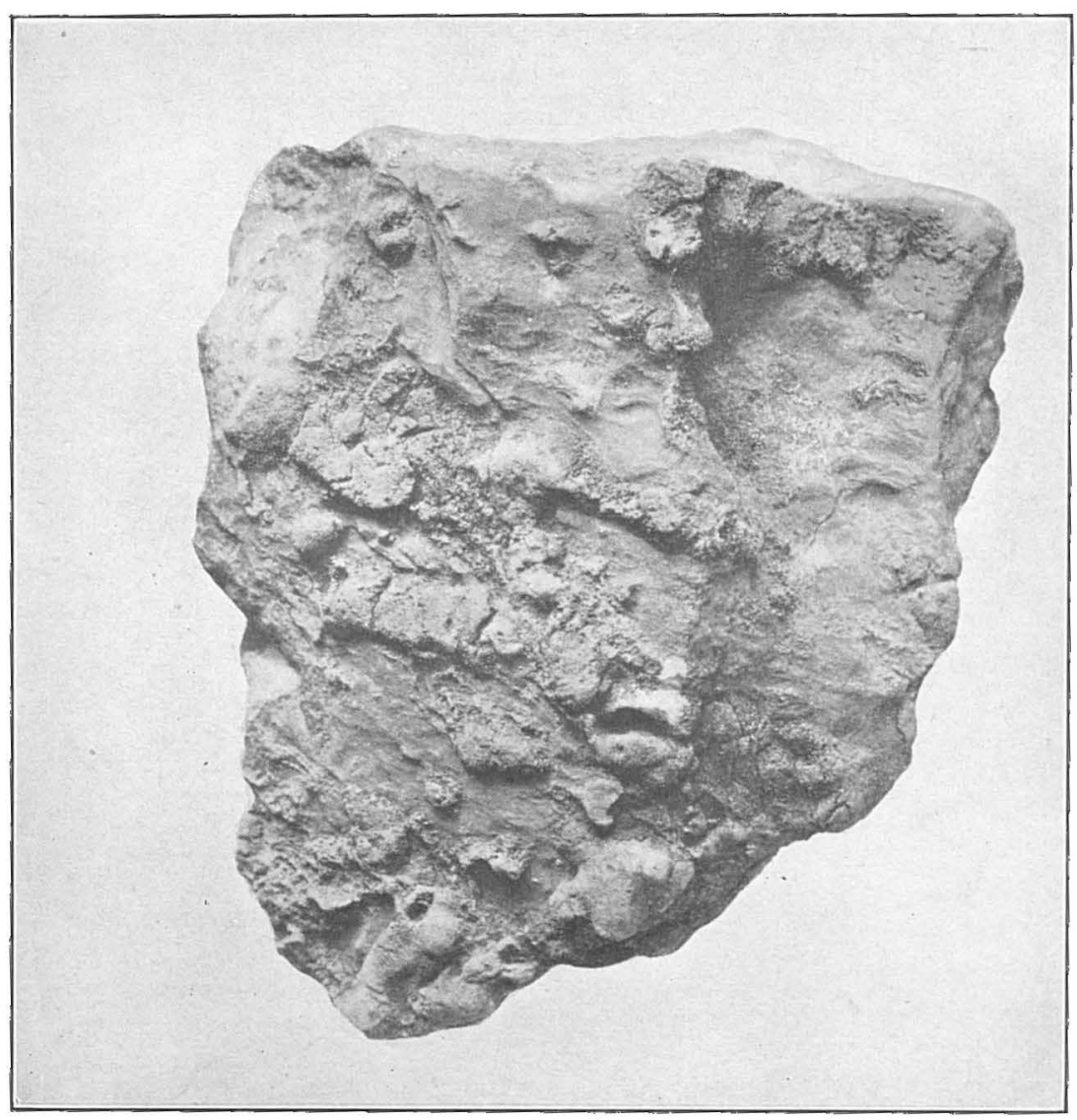

A. SPECIMEN OF GRANULAR CALCITE LIMESTONE WITH NODULES OF GRANULAR DOLOMITE IN RELIEF ON WEATHERED SURFACE.

Height, 4 inches. Typical of limestone of Hancock Valley, Mass.

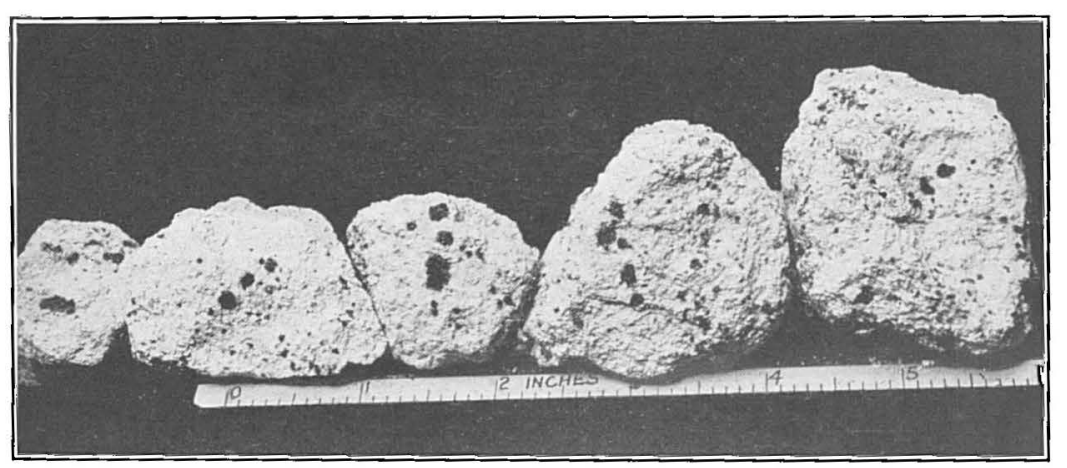

B. PIECES OF LIME WITH VITREOUS BLACK MAGNETIC SPHERULES RESULTING FROM THE BURNING OF PYRITIFEROUS DOLOMITE IN THE KILN.

Such dotomite is discarded, but when it chances to get into the kiln the product is thrown out. 
A specimen $(124, \mathrm{~b})$ of a similar dolomite from the same quarry, although only of medium-gray shade, is yet reported as making darkish lime. It contains more quartz than the last specimen.

\section{VARIETIES DISCARDED ON ACCOUNT OF TEXTURE OR CONTENT OF MAGNESIA.}

Coarse-grained calcite marble.-Some calcite marbles are discarded because the cohesion of their grains is so poor that when subjected to heat in an upright kiln they disintegrate and the granulated stone fills up the spaces between the blocks and chokes the flame so that the marble blocks never get thoroughly burned. The most striking example of this is the discarding by the Berkshire Hills Lime Co. at the Goodale quarry in Sheffield, of the thick bed of very coarse marble which was formerly quarried for construction and out of which Girard College in Philadelphia was built. ${ }^{10}$

At the Hoosac Valley Lime quarry in Adams it is found that calcite marble with a maximum diameter of over 1.85 millimeters will not burn through. This would throw out the rock of grades 6 and coarser.

Fine-grained calcite and dolomite marble.-Specimen D, XXXIX, 125, e, from the Tobey Lime quarry at West Stockbridge, is a fine-grained sugary cream-colored calcite and dolomite marble effervescing with acid test midway between calcite and dolomite. It is microscopically banded. There are untwinned grains up to 0.1 millimeter in diameter, probably dolomite, in more or less regular beds of minute thickness, alternating with like beds of twinned grains of calcite up to 0.75 millimeter in diameter. The texture of these beds would correspond to grades 0.1 and 3 , respectively. This stone is discarded because it operates under fire like a coarse calcite marble.

Fine-grained dolomiles.-Some fine-grained dolomites occurring interbedded with the calcite marbles are discarded because after passing through the kiln they hydrate rapidly-that is, they take up water from the air and disintegrate. The effect is that the lime from such a rock can not be shipped in bulk but has to be barreled, which adds to its cost. The rocks described below belong to this class.

Specimen D, XXXIX, 123, h, from the New England Lime Co.'s quarry at West Stockbridge, is a light bluish-gray even-grained dolomite with but very few twinned grains. The grain diameter is 0.025 to 0.125 (rarely 0.25 ) millimeter, estimated average 0.04 millimeter; grade 0.1 . It contains some quartz, muscovite, a little pyrite, rare grains of feldspar, also veinlets of calcite and quartz.

Specimen D, XXXIX, 124, a, from the C. I. Miller quarry, West Stockbridge, is a faintly bluish-white calcite and dolomite, effervescing with acid test midway between calcite and dolomite. It consists of two sorts of grains irregularly distributed-(1) not twinned, probably dolomite, diameter 0.025 to 0.1 millimeter, estimated average 0.037 millimeter, grade $0.1 ;(2)$ twinned grains, many clouded, with typical calcite twinuing, diameter 0.125 to 0.025 millimeter, estimated average 0.2 millimeter, grade 5. It contains a few quartz grains, rarely one of feldspar, a little pyrite. The following analysis was made by J. G. Fairchild, of this Survey:

$10 \mathrm{~A}$ microdrawing of the texture of this marble is shown in fig. 1 on p. 19 of $\mathrm{C}$. S. Geol. Survey Bull. 521. Owing to sccondary pressure the grains have bean flexed and the twinning planes show curvature. $21200-23-$ Bull. $744-3$ 
28 LIME BELT OF MASSACHUSETTS, NEW YORK, AND CONNECTICUT.

Analysis of magnesian calcite limestone from Miller quarry, West Stockbridge. ${ }^{11}$

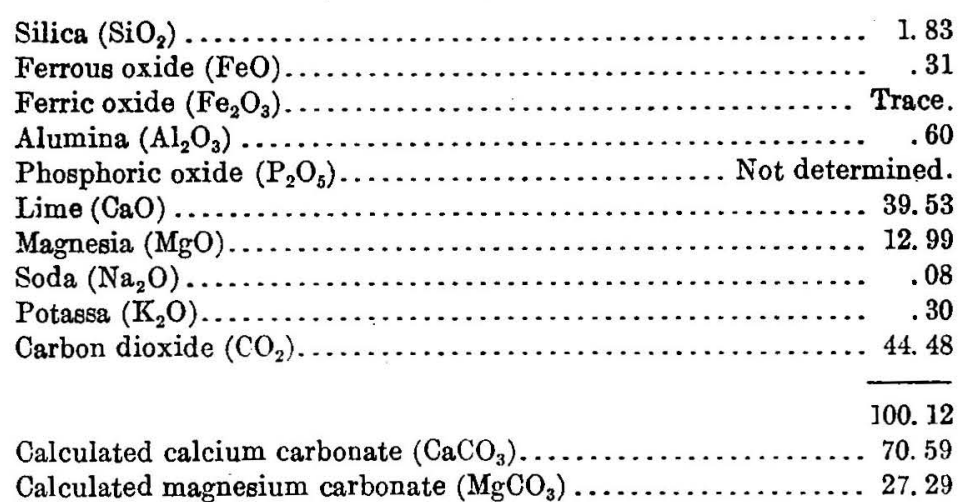

The analysis indicates the presence of quartz and feldspar in very small quantities. As a normal dolomite contains 54.35 per cent of lime carbonate and 46.65 per cent of magnesium carbonate, a proportionate amount of $\mathrm{CaCO}_{3}$, or 31.79 per cent, would have to be subtracted from the 70.59 per cent to be combined with the 27.29 per cent of $\mathrm{MgCO}_{3}$ to make a normal dolomite. The amount of normal dolomite in the rock is thus 59.08 per cent, leaving 38.80 per cent of uncombined $\mathrm{CaCO}_{3}$. This rock is therefore roughly 59 per cent dolomite and 41 per cent calcite.

\section{THE DOLOMITIC LIMESTONES.}

Dolomite ( $\mathrm{CaMg}\left(\mathrm{CO}_{3}\right)_{2}$, calcium and magnesium carbonate), is also used in the manufacture of lime, both "finishing lime" and "common lime." Objectionable minerals occur in the dolomitic limestones, as well as in the calcitic. These limestones will be described in the following order: (1) The twinned dolomites or marbles, (2) the varieties discarded on account of accessory minerals, (3) the granular and semigranular dolomites, including those interbedded with the calcitic limestones of Horizon III.

\section{DOLOMITES USED FOR MAGNESIAN LIME.}

Very coarse twinned.-Specimens D, XXXIX, 1, a, b, from the New England Lime Co.'s quarry about a mile east-northeast of Canaan village, in North Canaan Township, Conn., is of a light bluish-gray color and consists of twinned dolomite grains 0.555 to 1.85 millimeters in diameter, estimated average 0.47 millimeter; grade 6 (extra coarse A). These grains lie in a groundmass of untwinned dolomite grains 0.074 to 0.259 millimeter in diameter, estimated average 0.1 millimeter; grade 2 (very fine). Average diameter of all the grains estimated as 0.37 millimeter, grades 5 to 6 . The rock contains very little quartz.

Specimen D, XXXIX, 5, c, from the same company's quarry half a mile northwest of East Canaan, in the same township, is a bluish-white dolomite with streaks

\footnotetext{
II In this and four of the other analyses Mr. Fairchild has made a complete inspection of the insoluble matter, which be regards as fairly exact, considering the difficulty of separating a large mass of soluble chlorides from it. The calculations of the $\mathrm{MgCO}_{3}$ are based upon the $\mathrm{MgO}$ in the soluble matter only. Where the sum of the calculated $\mathrm{CaCO}_{3}$ and $\mathrm{MgCO}_{3}$ exceeds the sum of the $\mathrm{CaO}, \mathrm{MgO}$, and $\mathrm{CO}_{2}$, as it does in all but one of these analyses, it is possible that some of the $\mathrm{CaO}$ and $\mathrm{MgO}$ are in combination with $\mathrm{SiO}_{2}$ and the equivalent amounta of $\mathrm{Fe}$, etc., are in the form of carbonate.
} 
of light gray. It consists of twinned grains 0.185 to 1.85 millimeters in diameter, estimated average 0.46 millimeter; grade 6 . It contains rare scales of muscovite and minute specks of pyrite.

Coarse and medium, twinned.-Specimen $\mathrm{D}, \mathrm{XXXIX}, 2$, a, from the quarry of the Connecticut Lime Co. half a mile east-southeast of Canaan village, Conn., is a faintly bluish-white dolomite of twinned grains 0.11 to 2.85 millimeters in diameter, estimated average 0.3 millimeter; grade 5 (coarse). It contains extremely little quartz and pyrite. Specimen 2, b, from the same quarry, is slightly finer, about grade 4 (medium), and has streaks of pale-brownish mica (phlogopite).

Specimen D, XXXIX, 180, a, from the Standard Lime Co.'s quarry at Lee, is an extremely light grayish ("white") dolomite of interlocking twinned grains with a diameter of 0.074 to 1.1 millimeters, estimated average 0.24 millimeter; grade 5 (coarse).

Specimen D, XXXIX, 280, a, from the abandoned Maltby quarry, $1 \frac{3}{4}$ miles northwest of South Canaan, Conn., is a faintly cream-tinted dolomite of twinned grains 0.11 to 1.1 millimeters in diameter, estimated average 0.25 millimeter; grade 5 (coarse).

Fine, twinned.-Specimens D, XXXIX, 179, h, i, from the Lee Lime Co.'s quarry at Lee, is a faintly creamtinted ("white") dolomite of interlocking twinned grains, estimated average diameter 0.12 to 0.15 millimeter; grades 3 (fine) to 4 (medium). It contains a little pyrite and rarely a slender prism of tremolite up to 1 inch long.

Specimens D, XL, 38, a, b, from an outcrop a quarter of a mile north-northwest of the west portal of Hoosac Tunnel, in North Adams, represent a white sparkling dolomite of twinned grains, diameter 0.025 to 0.5 millimeter, esti-

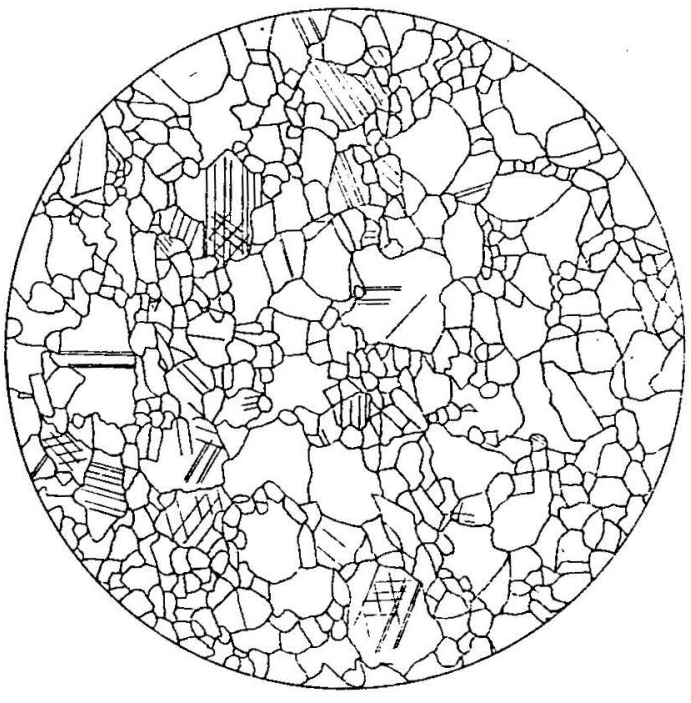

Figure 3.-Thin section of semigranular dolomite from the quarry of Kelley Island Lime \& Transport Co., two-fifths of a mile southeast of Dover Plains station, N. Y. Enlarged 21.7 diameters.

mated average 0.1 millimeter; grade 2 (very fine). It contains a little quartz and muscovite. This rock from its similarity to the foregoing seems to have economic possibilities.

Semigranular.-Specimen D, XL, 174, a, from the Kelley Island Lime \& Transport Co's. quarry, two-fifths of a mile southeast of Dover Plains station, Dutchess County, N. Y. (see Pl. IV), is a glistening faintly bluish-white dolomite of twinned and minute untwinned grains with an actual average grain diameter (calculated by Rosiwal method from microdrawing, fig. 3) of 0.0136 millimeter; grades 3 to 4 (fine to medium). This rock differs from the ordinary twinned dolomite (marble), like that of Lee and South Dover (pp. 60,64), by its content of a considerable number of minute untwinned grains, whereas in those marbles the small grains are larger, fewer, and nearly all twinned. It contains a little muscovite and quartz. In view of the occurrence of more or less tremolite, a silicate of calcium and magnesium, $i^{n}$ the dolomite of the region the dolomite of this quarry may contain a little of it. 
The following analysis was made by J. G. Fairchild, of this Survey:

Analysis of dolomite from quarry of Kelley Island Lime \& Transport Co., southeast of Dover Plains station, Dutchess County, N. Y.

Insoluble in acid (probably quartz and muscovite)

Soluble in acid:

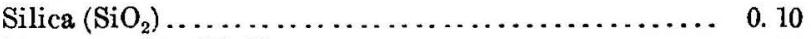

Ferrous oxide $(\mathrm{FeO}) \ldots \ldots \ldots \ldots \ldots \ldots \ldots \ldots \ldots \ldots \ldots . .25$

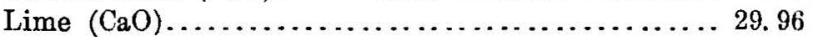

Magnesia (MgO)......................... 21.00

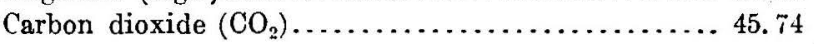

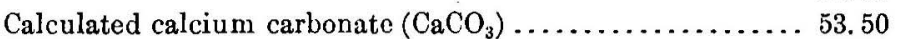

Calculated magnesium carbonate $\left(\mathrm{MgCO}_{3}\right) \ldots \ldots \ldots \ldots \ldots \ldots .44 .17$ Normal dolomite:

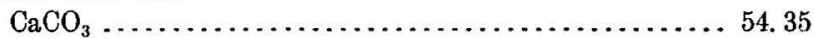

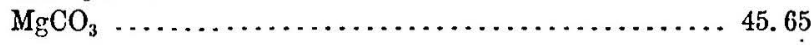

This rock contains 0.91 too much $\mathrm{CaCO}_{3}$ for a normal dolomite.

A granular dolomite from a bed in one of the Lee quarries, which is mixed with the twinned dolomite and used for lime, is described on page 36 and shown in figure 10.

VARIETIES DISCARDED ON ACCOUNT OF ACCESSORY MINERALS.

Micaceous.-Specimen D, XXXIX, 5, b, from the New England Lime Co. 's quarry half a mile northwest of East Canaan, Conn., is a whitish dolomite marble streaked with pale brown. It consists of medium-grained twinned dolomite, and the brownish laminae are due to a pale-brown mica, probably phlogopite. Pyrite and a little tremolite are also present. As the mica under intense heat would fuse to a glass, any considerable amount of it would be objectionable.

Pyritiferous.-Specimen D, XXXIX, 179, g, from one of the small dark beds in the cream-tinted dolomite of the Lee Lime Co.'s quarry at Lee, abounds with pyrite. Some of it is brilliantly iridescent. This was tested by Benedict Salkover, a chemist of this Survey, and found not to contain copper.

Specimens D, XXXIX, 1, c, and 1, cc, from the New England Lime Co.'s quarry 1 mile east-northeast of Canaan village, Conn., from a bed up to 2 feet thick known as the " gray bed." Its color is light bluish-gray. It consists of twinned dolomite of very irregular texture. In parts of the rock the grains have a maximum diameter of 2 millimeters and belong tó grade 5 (coarse) or 6 (extra coarse A). In other parts the grains belong to grade 3 (fine). In thin section the rock shows a little muscovite, some pyrite, and very little quartz, but in the mass it contains here and there cubes and grains of pyrite up to 0.1 inch in diameter. The lime from this bed is likely to contain bJack vitreous spherules as shown in Plate VIII, $B$. These are attracted by the magnet, and the kiln thus reproduces on a large scale the action of the blowpipe flame upon pyrite.

Specimen D, XXXIX, 5 , a, from a grayish bed in the eastern half of the quarry of the New England Lime Co. at East Canaan, Conn., consists of twinned dolomite with a few large crystals or grains of pyrite oxidized to limonite and sending out stains into the cleavage spaces. It contains also tremolite with inclusions of dolomite and a few scales of phlogopite.

Micaceous and pyritiferous. - Specimen D, XXXIX, 179, e, from one of the dark beds in the cream-tinted dolomite marble of the Lee Lime Co.'s quarry at Lee, is in the hand specimen a very micaceous medium-grayish limestone. A thin section from this consists of a jumble of muscovite, twinned calcite, and dolomite, also pyrite, with rare grains of quartz and minute particles of graplite. From the different effect 
of mica and pyrite upon lime already explained the combination of both would be very bad.

Tremolitic.-Specimen D, XXXIX, 179, d, from the most easterly of the three dark beds in the dolomite of the Lee Lime Co.'s quarry at Lee (see Pl. VII), is typical of this 12-inch bed. It is a fine-grained medium-gray dolomite with little darker beds alternating with lighter ones and all abounding with prisms of medium-gray tremolite, 0.1 to 0.2 inch wide and up to 6 inches in length, mostly parallel to the beds, with some mica along bed surfaces. The rock consists of twinned dolomite grains 0.05 to 0.5 millimeter in diameter, estimated average 0.12 millimeter, grade 3 (fine). It contains very little quartz, some pyrite, and a little fine graphite in the darker beds. The tremolite prisms show inclusions of carbonate, presumably dolomite, and thus demonstrate the secondary origin of the crystals.

Tremolite crystals occur in some of the beds of whitish dolomite at most if not all the quarries in Lee, Canaan, and North Canaan. Tremolite is a silicate of lime and magnesia and under intense heat fuses to a glass; therefore, dolomite that contains any amount of it is discarded.

Schistose with clastic quartz and feldspar grains.-At least one of the dark beds in the light dolomite of the Lee Lime Co.'s quarry at Lee contains very thin plicated beds of a fine-grained dark foliaceous rock. Specimen $\mathrm{D}, \mathrm{XXXIX}, 179, \mathrm{f}$, from one of these beds, consists of a schist of very fine quartz and graphite, without mica, but with nodules of pyrite at intervals. Within this schist and also on either side of it are strips or beds of sedimentary grains of quartz, plagioclase and microcline feldspar, together with carbonate (dolomite or calcite or both) and a pale-brownish mica

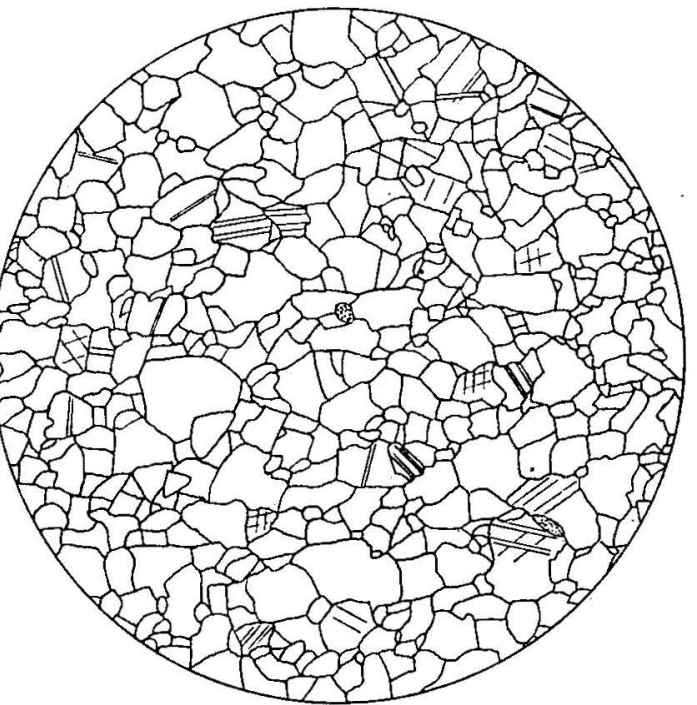

Figure 4.-Thin section of twinned dolomite from the disused quarry of the Kelley Island Lime \& Transport Co., three-quarters of a mile southeast of Dover Plains station, N.Y. Enlarged 29 diameters. Dotted grains are quartz.

(phlogopite), with spherules of pyrite. Some of these little beds are made up of coarser, and other of finer grains of quartz and feldspar. With these beds are also laminae consisting entirely of muscovite. Of course, all such material is discarded, but it has some scientific interest, for it shows that while the dolomite was being deposited there were intervals when fine granitic sand came into the sea. Thin sections of this rock afford a fine exhibit, in epitome, of the effects of sedimentation, crustal compression, metamorphism, and crystallization.

\section{VARIETY DISCARDED ON ACCOUNT OF BEHAVIOR UNDER FIRE.}

Vcry fine twinned dolomite.-Specimen D, XL, 208, a, from a disused quarry of the Kelley Island Lime \& Transport Co., three-quarters of a mile southeast of Dover Plains station, N. Y. (see Pl. IV), is a very light bluish-gray, in places white streaked, glistening dolomite of twinned grains with a diameter of 0.03 to 0.377 millimeter and an actual average diameter, calculated from the microdrawing shown in figure 4 , of 0.93 millimeter $(0.0036 \mathrm{inch})$. It thus belongs in texture grade 2 (very fine). 
It contains a little quartz and muscovite and still less feldspar and pyrite. Under kiln fire this rock passes into a fine sand that chokes the draft and prevents calcination. The quarry was therefore abandoned.

The following analysis was made by J. G. Fairchild, of this Survey:

Analysis of dolomite from quarry of Kelley Island Lime \& Transport Co. three-quarters of a mile southeast of Dover Plains station, Dutchess Counly, N. Y.

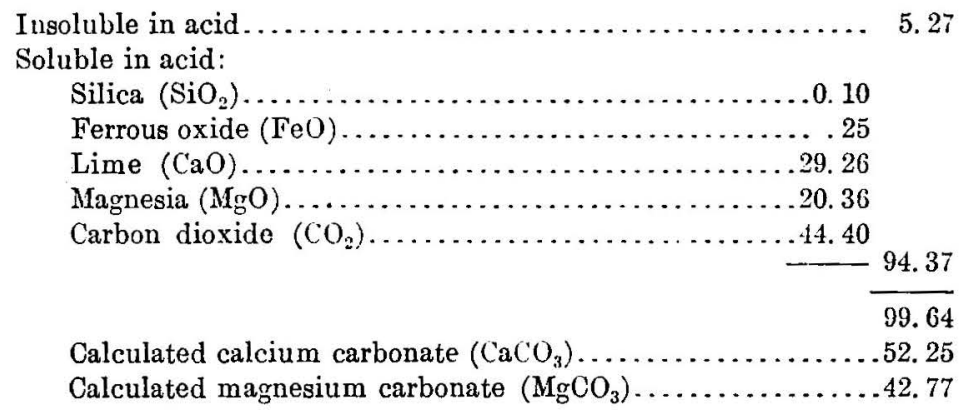

As the amount of $\mathrm{CaCO}_{3}$ required to form a normal dolomite with the calculated 42.77 per cent of $\mathrm{MgCO}_{3}$ is 49.82 per cent, this rock contains a surplus of 2.43 per cent of $\mathrm{CaCO}_{3}$. The insoluble 5.27 per cent represents quartz, feldspar, and mica. The rock may contain some tremolite (silicate of calcium and magnesium), which is abundant in the dolomite of the vicinity.

\section{GRANULAR AND SEMIGRANULAR DOLOMITIC LIMESTONES.}

Although the granular and semigranular dolomitic limestones, with two exceptions (specimens 174, a, p. 29 , and $180, \mathrm{~b}, \mathrm{p} .36$ ) are not now used in the lime industry, it will probably be found that they can all be burned in rotary kilns and some of them also in the upright kilns.

A number of these dolomites have been analyzed by J. G. Fairchild to show their availability in composition for the lime industry. $\mathrm{He}$ calculates in specimen 18, a (p. 52) from its content of 0.73 per cent of $\mathrm{FeO}$ the presence of 1.18 per cent of $\mathrm{FeCO}_{3}$ (iron carbonate); accordingly specimen $233, \mathrm{~b}$ (p. 41 ) has 1.29 per cent of $\mathrm{FeCO}_{3}$. As the percentages of $\mathrm{FeO}$ in the rest range from 0.16 to 0.41 their content of $\mathrm{FeCO}_{3}$ is negligible.

Thin sections of these rocks from widely separated outcrops have been studied and microdrawings made of typical textures. They fall into three well-marked textural groups-(I) even-textured, grades 0.1 (extra fine B) to 2 (very fine), with few or no twinned grains; (II) texture uneven or porphyroid, with very few twinned grains, texture of groundmass grades 0.1 to 1 ; (III) semigranular with many twinned and untwinned grains. In Groups I and II the surfaces are usually dull, rarely glistening, but in Group III they are usually glistening. 


\section{GROUP I. EVEN-TEXTURED, GRANULAR.}

Specimen D, XXXIX, 89, b, from southeast foot of Baldwin Hill, Egremont, about 1 mile southwest of Egremont Plain. Occurs in contact with beds of Horizon III. (See p. 15.) Cream-tinted. Grain diameter 0.01 to 0.1 millimeter, estimated average 0.025 millimeter; grade 1. Contains a little quartz and muscovite and generally disseminated pyrite in minute grains and crystals.

Specimen D, XXXIX, 85, a, from the same township but half a mile north of Egremont Plain, is of light-gray shade. Some of the grains cloudy. Diameter 0.02 to 0.3 millimeter, estimated average 0.06 millimeter; grade 1 . It contains very little quartz or mica and extremely little pyrite.

Specimen D, XXXIX, 98, a, from the Charles Ree place, in the southwest corner of Great Barrington, near South Egremont, is white. Grain diameter 0.02 to 0.2 millimeter. It contains extremely little quartz or mica,

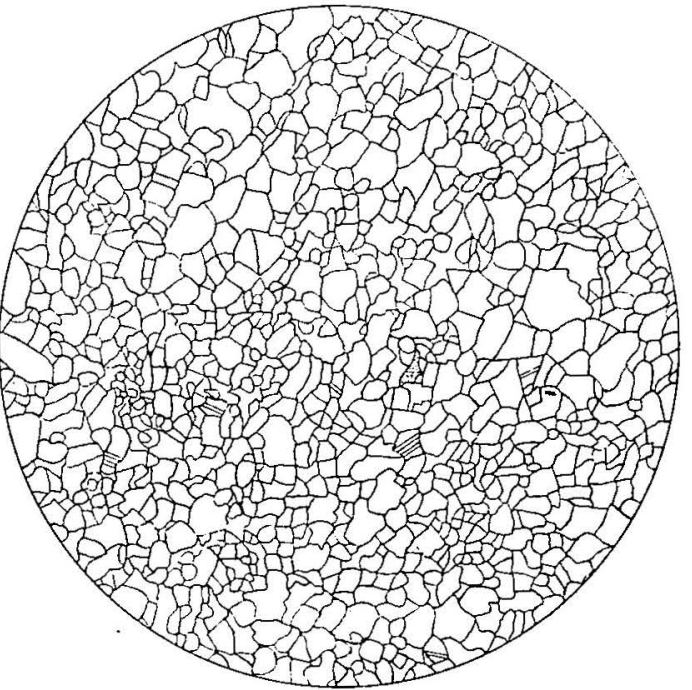

FIGURE 5.-Thin section of granulur white dolomite from the Charles Reed place, Great Barrington, Mass. Eularged 59.2 diameters. Dotted grain is quartz.

rare grains of feldspar, and exceptionally a group of cloudy dolomite grains of texture grade 3 . The general texture is shown in figure 5 . The average grain diameter calculated from this drawing is 0.0012 inch, or 0.03 millimeter (grade 0.1 ).

The following analysis of this stone was made by J. G. Fairchild, of this Survey:

Analysis of dolomite from Charles Reed place, Great Barrington, Mass.

Insoluble in acid (quartz, feldspar, and apatite).

1. 78

Soluble in acid:

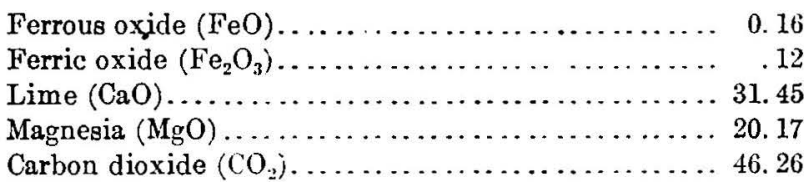

Calculated calcium carbonate $\left(\mathrm{CaCO}_{3}\right) \ldots \ldots \ldots \ldots \ldots \ldots \ldots . \ldots \ldots . \ldots \ldots$

Calculated magnesium carbonate $\left(\mathrm{MgCO}_{3}\right) \ldots \ldots \ldots \ldots \ldots \ldots . . \ldots 2.37$

As the amount of $\mathrm{CaCO}_{3}$ required to form a normal dolomite with the calculated 42.37 per cent of $\mathrm{MgCO}_{3}$ is 49.57 per cent, this rock contains a surplus of 6.59 per cent of $\mathrm{CaCO}_{3}$.

Specimen D, XXXIX, 129, b, from the road fork 2 miles southwest of West Stockbridge, is white with a few clouded grains. Grain diameter 0.02 to 0.3 millimeter, estimated average 0.066 millimeter; grade 1 . It contains very few quartz 


\section{LIME BELT OF MASSACHUSETTS, NEW YORK, AND CONNECTICUT.}

grains, very rarely a feldspar, extremely little pyrite. The following analysis was made by J. G. Fairchild, of this Survey:

Analysis of dolomite from road fork 2 miles southwest of West Stockbridge, Mass.

Insoluble in acid (quartz and feldspar)

Soluble in acid:

Ferrous oxide $(\mathrm{FeO}) \ldots \ldots \ldots \ldots \ldots \ldots \ldots \ldots \ldots \ldots, 0.31$

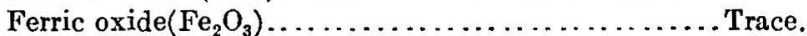

Phosphoric oxide $\left(\mathrm{P}_{2} \mathrm{O}_{6}\right) \ldots \ldots \ldots \ldots \ldots$ Not determined.

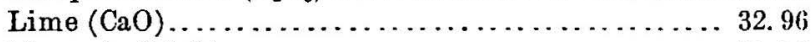

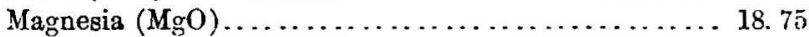

Carbon dioxide $\left(\mathrm{CO}_{2}\right) \ldots \ldots \ldots \ldots \ldots \ldots \ldots \ldots \ldots .78$

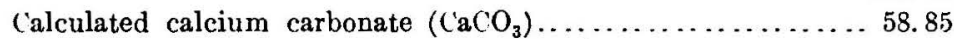

Calculated magnesium carbonate $\left(\mathrm{MgCO}_{3}\right) \ldots \ldots \ldots \ldots \ldots \ldots . \ldots . \ldots 39$

As the amount of $\mathrm{CaCO}_{3}$ required to form a normal dolomite with the calculated 39.39 per cent of $\mathrm{MgCO}_{3}$ is 45.89 per cent this rock contains a surplus of 12.96 per cent of $\mathrm{CaCO}_{3}$.

Specimen D, XXXIX, I43, a, from a conspicuous knoll half a mile southeast of the West Stockbridge Marble Works quarry, is whitish, with grain diameter 0.05 to 0.1 millimeter; estimated average 0.058 millimeter; grade 1 . It contains much quartz and fine pyrite, rarely a feldspar, and no mica. The following analysis was made by J. G. Fairchild, of this Survey:

Analysis of dolomite from knoll half a mile southeast of West Stockbridge Marble

Silica $\left(\mathrm{SiO}_{2}\right)$. 11.03

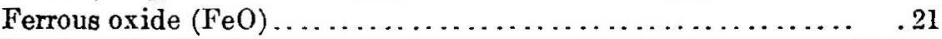

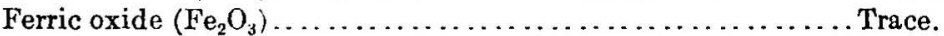

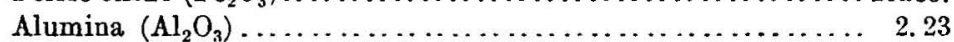

Phosphoric oxide $\left(\mathrm{P}_{2} \mathrm{O}_{3}\right) \ldots \ldots \ldots \ldots \ldots \ldots \ldots \ldots$ Not determined.

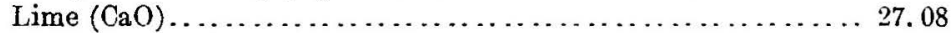

Magnesia $(\mathrm{MgO})$ (soluble in acid 18.06) ................. 18.18

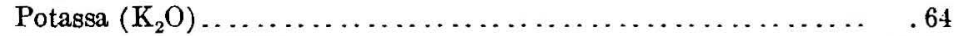

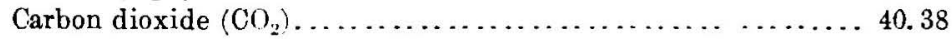

99.75

Calculated calcium carbonate $\left(\mathrm{CaCO}_{3}\right) \ldots \ldots \ldots \ldots \ldots \ldots \ldots . . \ldots \ldots .35$

Calculated magnesium carbonate $\left(\mathrm{MgCO}_{3}\right) \ldots \ldots \ldots \ldots \ldots \ldots \ldots . . . \ldots 4$

As the amount of $\mathrm{CaCO}_{3}$ required to form a normal dolomite with the calculated 37.94 per cent of $\mathrm{MgCO}_{3}$ is 44.20 per cent this rock contains a surplus of 4.15 per cent of $\mathrm{CaCO}_{3}$. The high percentage of silica will be noticed. From the thin-section results and the analysis of the insoluble matter this rock contains, besides much quartz, some feldspar and probably a little tremolite.

The granular dolomite from the anticline at the Truesdell quarry (north), in West Stockbridge, referred to on page 45 and described microscopically on page 51 (specimen D, XXXIX, 171, a), was also analyzed by Mr. Fairclitild. 
Analysis of dolomite in anticline at Truesdell quarry (north), West Stockbridge, Mass.

Insoluble in acid (probably largely quartz and muscovite)...... 6. 22

Soluble in acid:

Ferrous oxide $(\mathrm{FeO}) \ldots \ldots \ldots \ldots \ldots \ldots \ldots \ldots \ldots, 0.41$

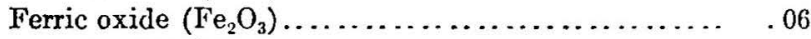

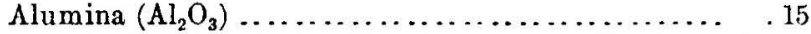

Phosphoric oxide $\left(\mathrm{P}_{2} \mathrm{O}_{5}\right) \ldots \ldots \ldots \ldots \ldots$ Not determined.

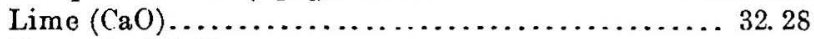

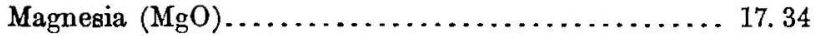

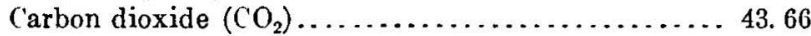

Calculated calcium carbonate $\left(\mathrm{CaCO}_{3}\right) \ldots \ldots \ldots \ldots \ldots \ldots \ldots . . \ldots . . \ldots$

(alculated magnesium carbonate $\left(\mathrm{MgCO}_{3}\right) \ldots \ldots \ldots \ldots \ldots \ldots \ldots, 36.42$

As the amount of $\mathrm{CaCO}_{3}$ required to form a normal dolomite with the calculated 36.42 per cent of $\mathrm{MgCO}_{3}$ is 42.42 per cent, this rock shows a deficiency of 2.64 per cent of $\mathrm{CaCO}_{3}$.

Specimen D, XXXIX, 173, a, from the Jesse Bliss farm, south of State line and 2 miles west of West Stockbridge, in the same township, is a white-weathering whitish dolomite of untwinned grains, 0.01 to 0.075 millimeter in diameter. It contains a little quartz and feldspar, very little mica, and exceedingly little pyrite. The fineness of its texture is quite exceptional. Its average grain diametes calculated from a microdrawing, but excluding the quartz and feldspar grains, is 0.012 millimeter $(0.0004$ inch $)$, or one-half the usual average for grade 1 ; but as the thin section ohowed many spaces between the grains filled with particles too minute for measurement the calculated diameter is too high.

Specimen D, XXXIX, 198, a, from the west end of Laurel Lake, in Lenox Township, is buff-colored, with grain diameter 0.025 to 0.375 millimeter; estimated average 0.066 millimeter; grade 1 . The section shows neither quartz, mica, nor pyrite.

Specimen D, XXXIX, 251, a, from the east side of a hilltop east of Dean's Mill, Adams, is bluish white, with grain diameter 0.025 to 0.375 millimeter; estimated average 0.08 millimeter; grades 1 to 2 . It contains a little quartz, scarcely any pyrite, no mica. The following analysis was made by J. G. Fairchild, of this Survey:

Analysis of dolomite from hilltop cast of Dean's Mill, Adams.

Insoluble in acid

Soluble in acid:

Ferrous oxide $(\mathrm{FeO}) \ldots \ldots \ldots \ldots \ldots \ldots \ldots \ldots \ldots \ldots, 0.28$

Ferric oxide $\left(\mathrm{Fe}_{2} \mathrm{O}_{3}\right) \ldots \ldots \ldots \ldots \ldots \ldots \ldots \ldots \ldots \ldots \ldots \ldots \ldots$ Trace.

Alumina $\left(\mathrm{Al}_{2} \mathrm{O}_{3}\right) \ldots \ldots \ldots \ldots \ldots \ldots \ldots \ldots \ldots \ldots \ldots \ldots \ldots \ldots \ldots \ldots . . .10$

Phosphoric oxide $\left(\mathrm{P}_{2} \mathrm{O}_{5}\right) \ldots \ldots \ldots \ldots \ldots$. . . . . .

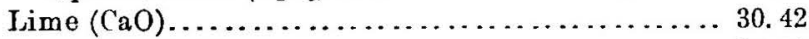

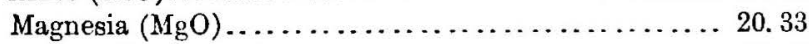

Carbon dioxide $\left(\mathrm{CO}_{2}\right) \ldots \ldots \ldots \ldots \ldots \ldots \ldots \ldots . \ldots \ldots .45$

Calculated calcium carbonate $\left(\mathrm{Ca}^{\mathrm{C}} \mathrm{O}_{3}\right) \ldots \ldots \ldots \ldots \ldots \ldots \ldots . . \ldots 4.32$

Calculated magnesium carbonate $\left(\mathrm{MgCO}_{3}\right) \ldots \ldots \ldots \ldots \ldots \ldots . .72 .71$ 


\section{LIME BELT OF MASSACHUSETTS, NEW YORK, AND CONNECTICUT.}

As the amount of $\mathrm{CaCO}_{3}$ required to form a normal dolomite with the calculated 42.71 per cent of $\mathrm{MgCO}_{3}$ is 49.75 per cent, this rock contains a surplus of 4.57 per cent $\mathrm{CaCO}_{3}$. The 3.63 per cent of insoluble matter consists mainly of quartz, with probably some feldspar.

Specimen D, XXXIX, 259, b, represents two 4-foot beds in the Dean quarry of the Cheshire Lime $\mathrm{Co}$. in Cheshire. It is medium gray, with grain diameter 0.025 to 0.25 millimeter; grade 1 . It contains evenly and sparsely disseminated minute scales of muscovite, a little quartz, a few grains of feldspar, and extremely little pyrite. It is discarded.

In places the grains of these granular dolomites have a more angular outline, as in the section shown in figure 6 of specimen $\mathrm{D}, \mathrm{XL}, 152, \mathrm{~b}$, from a point 1 mile northeast of Canaan, N. Y. (See Pl. II.) This is also shown on a much more minute scale, but less distinctly, in figure 7; a section of specimen $\mathrm{D}, \mathrm{XL}, 143$, a, from the west foot of the Taconic Range in Hillsdale N. Y. (see PI. III), which is typical of the dolomite of that section.

In other places these dolomites have grains with sinuous outlines due in part to the presence of minute interstitial grains as shown in figure 8, representing specimen D, XL, 21, a, from Phelps Knoll, near South Williamstown. (See Pl. I.)

\section{GROUP II. UNEVEN OR PORPHYROID TEXTURE, GRANULAR.}

Specimen D, XXXIX, 75, a, from railroad cut at Cande's Cobble, 1 mile south of Sheffield village (PI. III), is white with light bluish-gray streaks and consists of twinned dolomite grains 0.125 to 0.375 millimeter in diameter, in a groundmass of untwinned grains with an estimated average diameter of 0.2 millimeter; grade 0.1 . It contains a little tremolite, some quartz, and muscovite.

Specimen D, XL, 129, a, from the ledge three-quarters of a mile northwest of Monterey village (PI. III), referred to on page 18, is a very light bluish-gray dolomite of porphyroid texture with twinned grains 0.2 to 0.82 millimeter in diameter, lying in a groundmass of untwinned grains of estimated average diameter 0.04 millimeter (grade 0.1 ), as shown in figure 9. It contains very little quartz and little or no pyrite.

Specimen D, XXXIX, 165, a, from Richmond, three-quarters of a mile north of Careys Corners, is cream-colored aud consists of dolomite grains mostly clouded, some twinned up to 0.25 millimeter in diameter, in a groundmass of untwinned grains of estimated average 0.016 millimeter; grade 0.1 .

Specimen D, XXXIX, 180, b, from a bed in the Standard Lime Co.'s quarry at Lee, is cream-tinted and consists of twinned grains 0.125 to 0.5 millimeter in diameter lying in a groundmass of untwinned grains of estimated average diameter much less than 0.037 millimeter; grade 0.1 . It contains muscovite up to 0.75 millimeter, almost no quartz, and extremely little pyrite. This stone is burned with the twinned dolomite of the other beds. Its texture is shown in figure 10 .

Specimen D, XXXIX, 256, a, from a small, disused building-stone quarry at the west end of Néwark Avenue in Zylonite, Adams (Pl. I), is white and consists of clouded grains, some of them twinned, 0.26 to 1.85 millimeters, lying in a groundmass of untwinned grains of grade 1 . It contains very little quartz or mica and some pyrite.

Specimen D, XXXIX, 245, a, from a small opening near the Upton house in Adams, is white and consists of cloudy grains, some twinned, 0.375 to 0.875 millimeter in diameter, lying in a groundmass of untwinned grains of estimated average diameter 0.05 millimeter; grades 0.1 to 1 . It contains very little quartz, a little mica in parts, and extremely little pyrite. Its texture is shown in figure 11. 


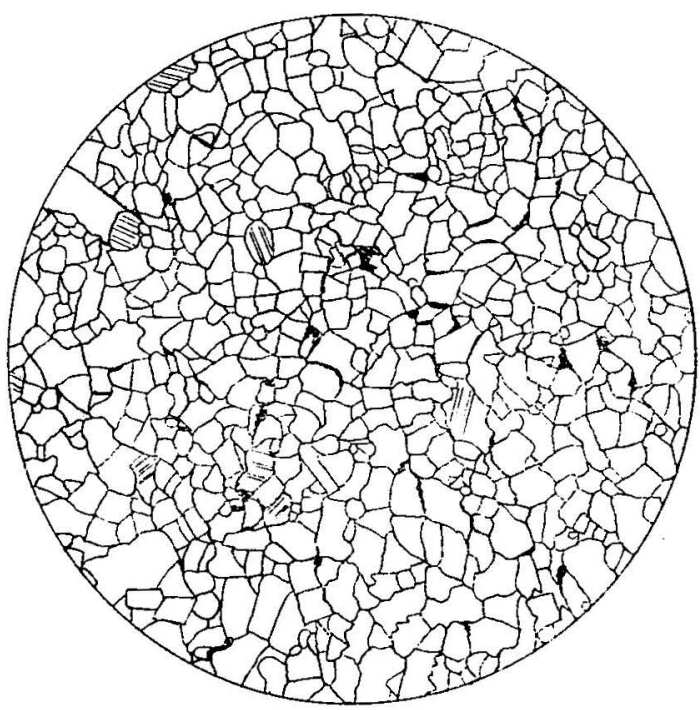

Figure '6. - Thin se cim of granutur dolomite, associated with granular calcite limestono, at a point 1 mile northenst of Canıan, X. Y. Many of the grains are angular, being eitrer rhombs or distorted rhombs, A fow are twinned. The black streaks are graphite and p;rite. Enlare 129.7 diamiters.

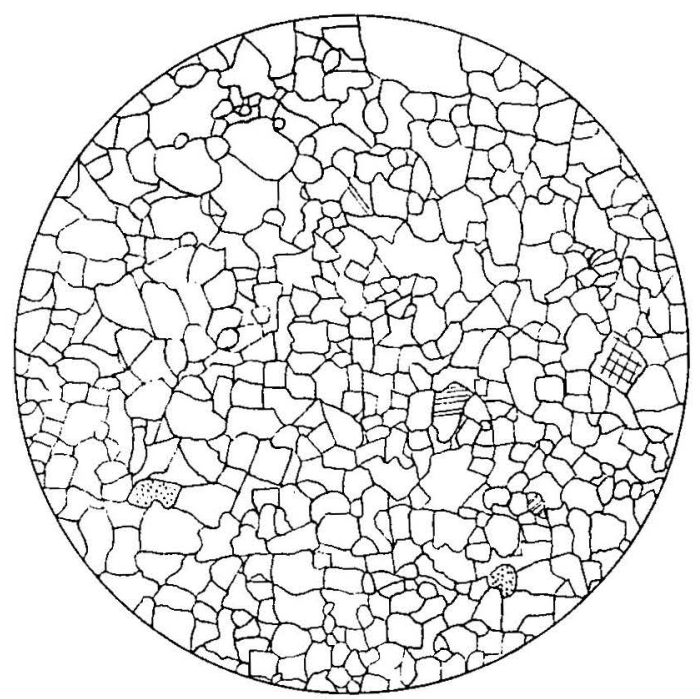

Figure 7.-Thin section of granular dolomite from knoll in Hillsdale, N. Y., 3 miles west of North Egrcmont, Mass. The dotted grains are quartz, the cross-lined grain microcline feldspar. Enlarged 91 diameters. 


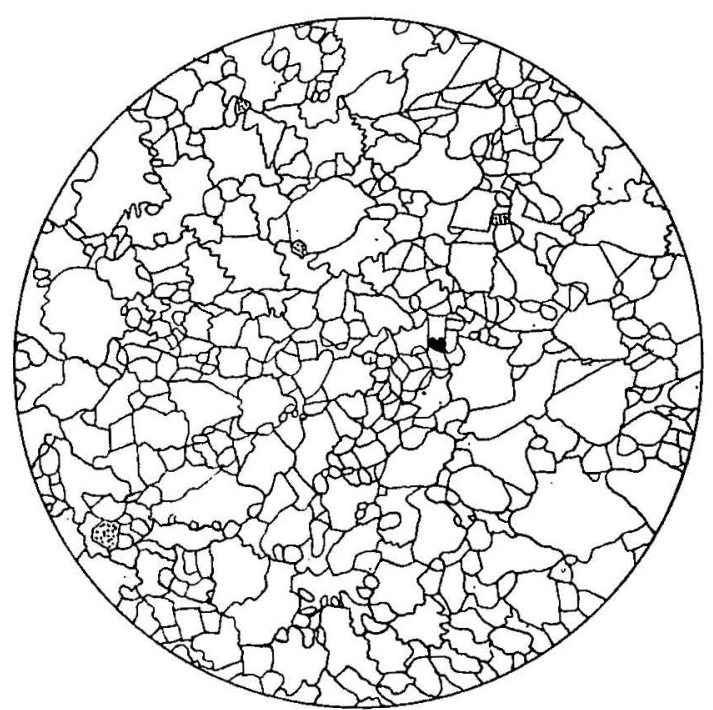

Figure 8.--Thin section of granular dolomite from the top of Phelps Knoll, near South Williamstown. The dotted grains are quartz, the black grains pyrite. Enlarged 39.7 diameters.

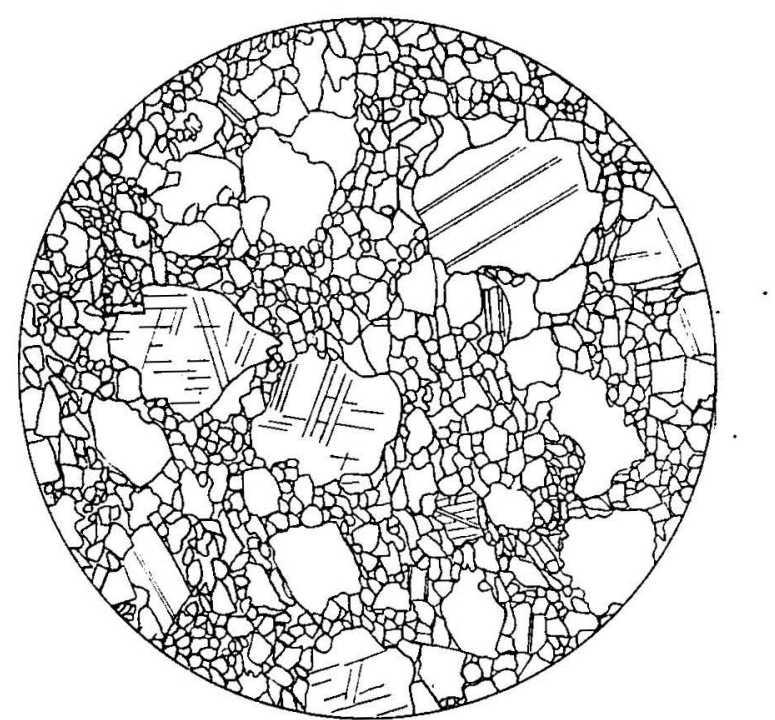

FIGURE 9.-Thin'scetion of porphyroid granular dolomite from road cut naar Monterey village, Berkshire County, Mass. Enlarged 21.8 diameters. 


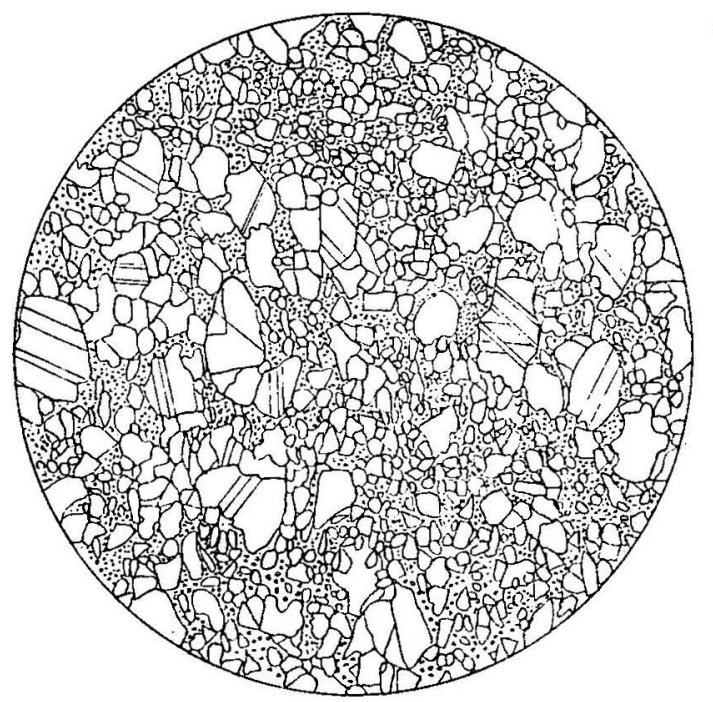

Figure 10.-Thin section of porphyroid granular dolomite from the Standard Lime Co.'s quarry it Lee, Mass. The dotted grain is cluartz; the interstitial dots and circles represent grains of excessi : 0 minuteness. Entarged 32 diameters.

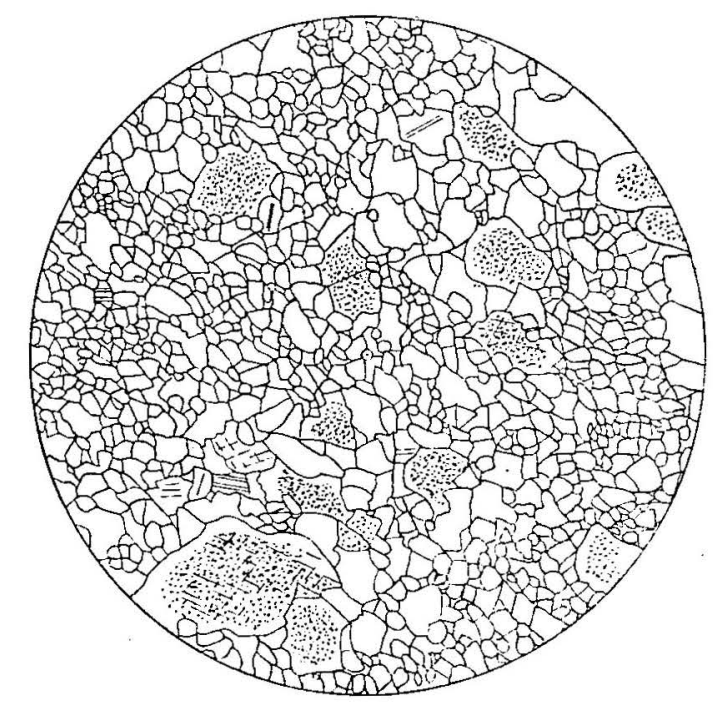

FIGURE 11.-Thin section of white porphyroid granular dolomite from opening near Upton's, Adams, Mass. The dotted areas in the largo grains represent aggregations of grains measuring each 0.0028 to 0.0085 millimeter in diameter. Some of these are rhombs and polarize. Enlarged 20 diameters. 
40 LIME BELT OF MASSACHUSETTS, NEW YORK, AND CONNECTICUT.

The following analysis of this stone was made by J. G. Fairchild, of this Survey:

Analysis of dolomite from opening near Upton's, Adams, Mass.

Insoluble in acid (quartz and possibly mica). 0. 78

Soluble in acid:

Ferrous oxide $(\mathrm{FeO})$ 0.25

Ferric oxide $\left(\mathrm{Fe}_{2} \mathrm{O}_{3}\right) \ldots \ldots \ldots \ldots \ldots \ldots \ldots \ldots \ldots \ldots \ldots \ldots$ Trace.

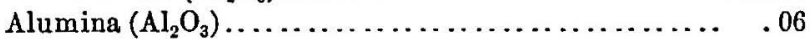

Phosphoric acid $\left(\mathrm{P}_{2} \mathrm{O}_{5}\right) \ldots \ldots \ldots \ldots \ldots$ Not determined.

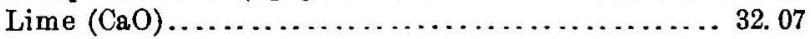

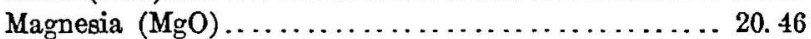

Carbon dioxide $\left(\mathrm{CO}_{2}\right) \ldots \ldots \ldots \ldots \ldots \ldots \ldots \ldots \ldots . \ldots \ldots 4.64$

$-29.48$

100. 26

Calculated calcium carbonate $\left(\mathrm{CaCO}_{3}\right) \ldots \ldots \ldots \ldots \ldots \ldots \ldots \ldots \ldots \ldots \ldots \ldots .26$

Calculated magnesiom carbonate $\left(\mathrm{MgCO}_{3}\right) \ldots \ldots \ldots \ldots \ldots \ldots .42 .98$

As the amount of $\mathrm{CaCO}_{3}$ required to form a normal dolomite with the calculated 42.98 per cent of $\mathrm{MgCO}_{3}$ is 49.84 per cent, this rock contains a surplus of 7.42 per cent of $\mathrm{CaCO}_{3}$.

\section{GROUP III. SEMIGRANUIAR.}

Specimen D, XXXIX, 61, a, from a prospect of the Berkshire Hills Lime? ('o. about $2 \frac{1}{4}$ miles north-northrest of Sheffield villare, is white. Grain diameter 0.025

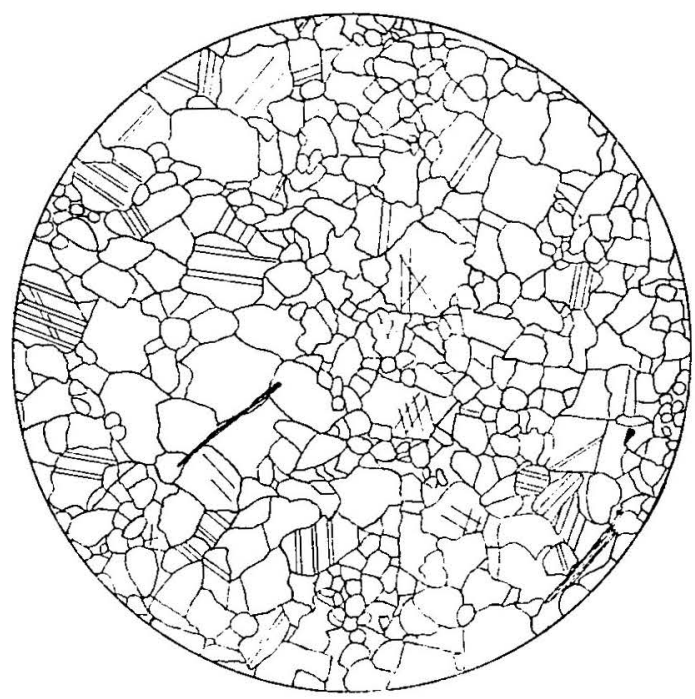

FIGURE 12.-Thin section of very light bluish-gray semigranular dolomite from ledge half a mile southwest of Rattlesnake Hill, Stockbridge, Mass. Enlarged 39.7 dismeters. Longitudinally shaded grains are muscovite, the black grain pyrite. to 0.3 millimeter, estimated average 0.07 millimeter; a little coarser than grade 1 and uneven. It contains a little quartz and pyrite.

Specimen D, XXXIX, 129 , a, from an old prospect west of the road fork 2 miles southwest of West Stockbridge, is whitish with some clouded grains. Estimated average diameter 0.08 millimeter; grades 1 to 2. It contains a little quartz and muscovite, rarely a grain of feldspar, also sonie spherules and crystals of pyrite.

Specimen D, XXXIX, 230, a, from the southwest ioot of Rattlesnake Hill, Stockbridge, is an extremely light bluish-gray rock with grain diameter 0.02 to 0.25 millimeter; grade 1 . Its calculated average diameter from the microdrawing (fig. 12) is 0.61 millimeter $(0.0024$ inch), corresponding to its estimated average. It contains rare grains of quartz and scales of muscovite with extremely little pyrite. 
The following analysis was made by J. G. Fairchild, of this Survey:

Analysis of dolomite from southwest foot of Rattlesnake Hill, Stockbridge.

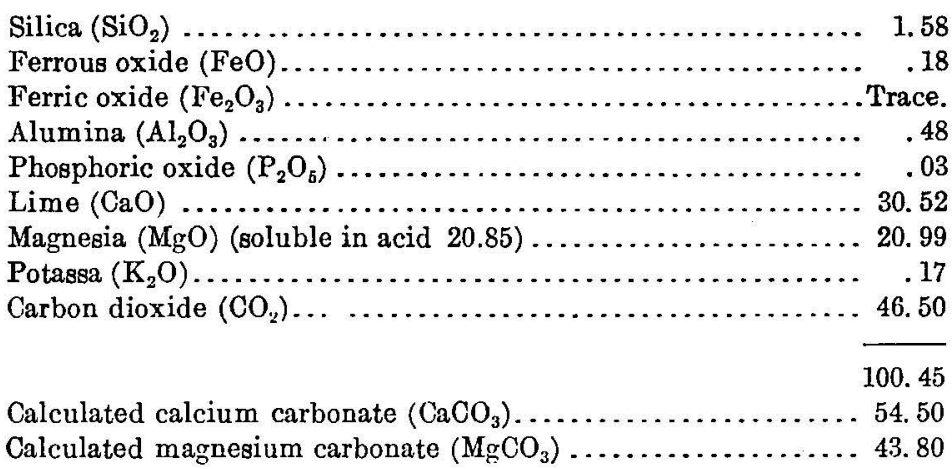

As the amount of $\mathrm{CaCO}_{3}$ required to form a normal dolomite with the calculated 43.80 per cent of $\mathrm{MgCO}_{3}$ is 51.02 per cent, this rock contains a surplus of 3.48 per cent of $\mathrm{CaCO}_{3}$. The analysis indicates the presence of quartz, feldspar, and possibly a little tremolite.

Specimen D, XXXIX, 233, b, from the abandoned Hutchinson quarry, 2 miles north-northeast of Lenox, is whitish and occurs interbedded with calcite marble. Its estimated average grain diameter is 0.066 millimeter; grade 1 . It contains a little quartz, some muscovite, rarely feldspar. The following analysis was made by J. G. Fairchild, of this Survey:

\section{Analysis of dolomite from Hutchinson quarry, Lenox.}

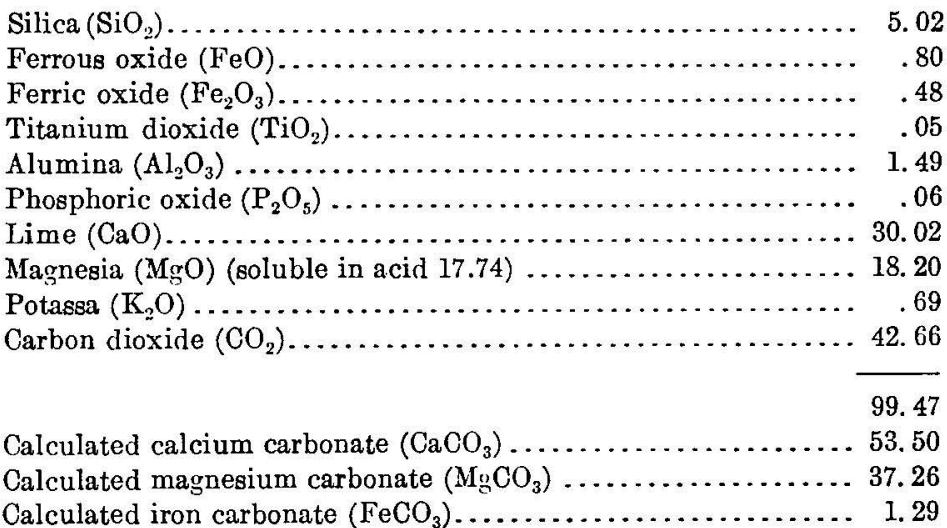

As to make a normal dolomite only 43.31 per cent of the $\mathrm{CaCO}_{3}$ would be required to be combined with the calculated 37.26 per cent of $\mathrm{MgCO}_{3}$ this rock contains a surplus of 10.19 per cent of $\mathrm{CaCO}_{3}$. The analysis indicates the presence of quartz, feldspar, and phlogopite.

Specimen D, XXXIX, 214, a, from an outcrop about 600 feet northeast of the New England Lime Co.'s Renfrew quarry in Adams, is white with grayish streaks and has an estimated average grain diameter of 0.08 millimeter; grades 1 and 2 . It contains a little quartz, extremely little pyrite, and no mica. The following analysis was made by J. G. l'airchild, of this Survey. 
Analysis of dolomite from outcrop near the New England Lime Co.'s Renfrew quarry, Adams, Mass.

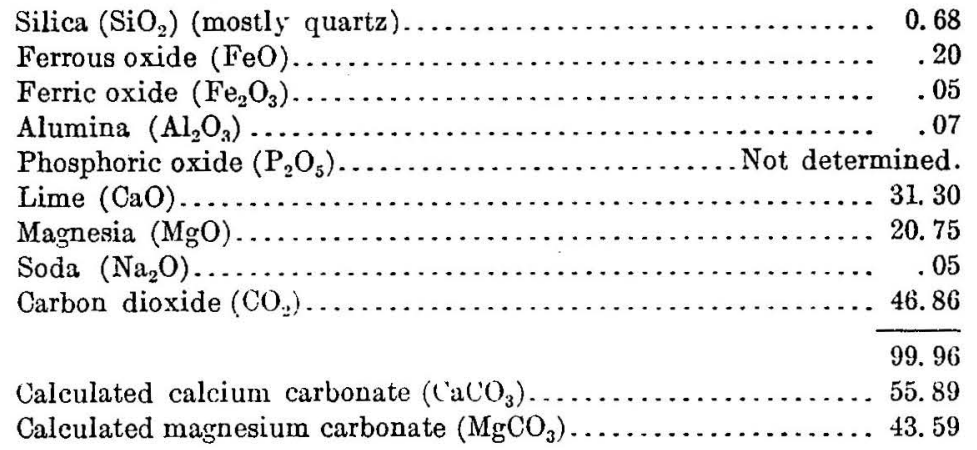

As to make a normal dolomite only 50.80 per cent of the $\mathrm{CaCO}_{3}$ would be required to be combined with the calculated 43.59 per cent of $\mathrm{MgCO}_{3}$ this rock contains a surplus of 5.09 per cent of $\mathrm{CaCO}_{3}$.

Although some of these dolomites may be found by experiment to be physically unsuitable for the manufacture of lime on account of their behavior under heat, yet the chief reason for their not having been thus used hitherto seems to have been ignorance both of their location and their chemical composition.

The dolomites with rather high content of silica are represented by specimens 233 , b (p. 41), with 5.02 per cent; 208, a (p. 32), with 5.27 per cent; 171 , a (p. 35), with 6.22 per cent; and 143, a (p. 34), with 11.03 per cent. Of these No. 208, a, has been used for lime without difficulty on account of its silica, but the percentage in No. 143, a (11.03) is probably too high.

\section{GRANULAR CALCITIC LIMESTONE AND ASSOCIATED DOLOMITE.}

As stated on page 3 and shown on Plates I and II, the Stockbridge limestone, at least its upper calcitic portion and probably part of its lower dolomitic portion, passes westward along the Taconic Range into a granular limestone associated with granular dolomite. This limestone is genorally light bluish or dark gray, lusterless, and thinly foliated. In thin section it consists of untwinned (or with rare twinned grains) polarizing grains of calcite of very minute size. At locality 164, in Stephentown, N. Y., their diameter is 0.008 to 0.0043 millimeter, estimated average 0.007 millimeter. At Butternut Hill, in the same township, their diameter is 0.0043 to 0.08 millimeter, estimated average 0.017 millimeter; at North Petersburg, N. Y., 0.01 to 0.066 millimeter, estimated average 0.019 millimeter; and at locality 151, in Canaan, N. Y., 0.004 to 0.01 millimeter, estimated average 0.005 millimeter. In places the rock contains graphite and pyrite or grains of quartz and feldspar or streaks of twinned calcite grains. 
At locality 161, $1 \frac{1}{4}$ miles south of Berlin station, N. Y., on the road leading west, the typical granular limestone has a grain diameter of 0.01 to 0.076 millimeter with an estimated average of 0.02 millimeter. Figure 13 shows a thin section of it. The calculated av- erage diameter of the grains drawn is 0.0078 inch or 0.02 millimeter, as was estimated by micrometer, which makes the rock 50 per cent finer than the average grade (0.1).

Dolomite occurs either as beds or lenses or grains within the granular calcite limestone. The dolomite lenses at locality 161 , in

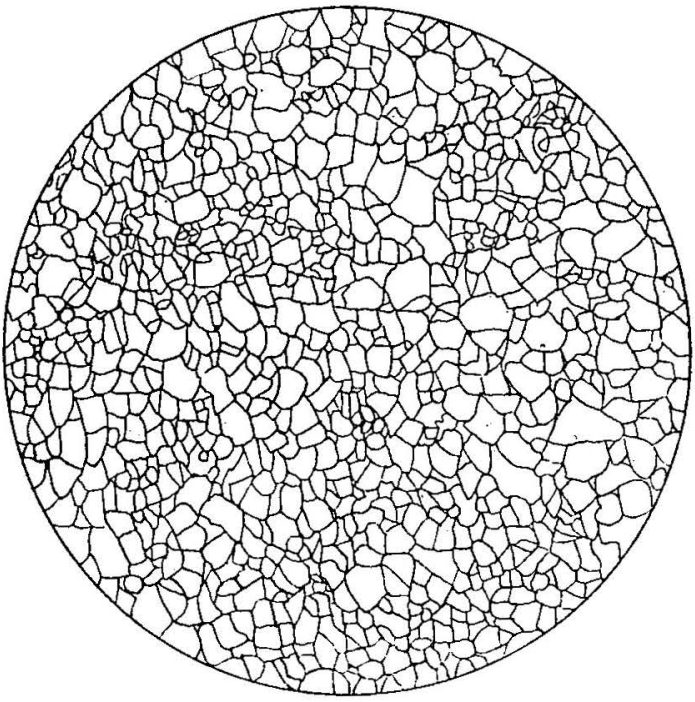

FIGURE 13.-Thin section of granular calcite limestone from locality 161, if miles south of Berlin station, Rensselser County, N. Y. Enlarged 89 diameters.

Berlin, consist of 'granular dolomite of group I with rarely a twinned

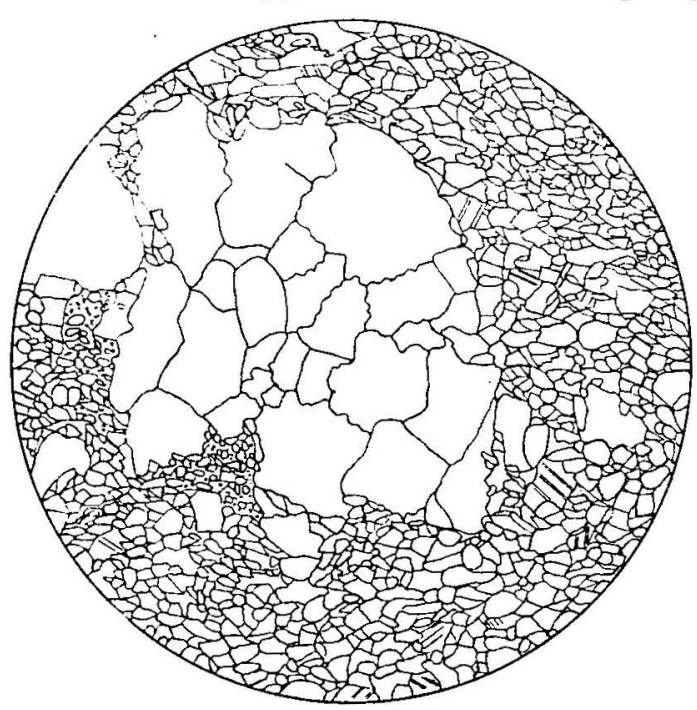
grain. Its average calculated grain diameter is 0.9 millimeter and its texture therefore grade 2 (very fine). The interbedded dolomite is also granular, and much of it belongs in grade 1 .

In the valley of the West Branch of the Hoosic, known locally as the Hancock Valley, much of the limestone not far below the schist of Horizon IV is marked by nodules of buff to mediumgray dolomite, 0.1 to 0.3

FIgURE 14.-Thin section of nodule of granular dolomite in granular calcitc limestone from locality 69,3 miles southwest of South Williamstown, in Hancock, Mass., on the 1,140-font level. Eninch in diameter, and strings of them projectlarged 49.7 diameters. A few of the calcite grains are twinned. ing in relief on the weathered surface as shown in Plate VIII, $A$. Their rough granular surface $21200-23-$ Bull. $744-4$ 
contrasts with the bluish-gray smooth surface of the limestone. A thin section of one of these nodules is shown with the inclosing granular calcite in figure 14 . In some places the granular limestone contains either minute lenses of dolomite or generally disseminated minute rhombic grains of it and thus becomes a dolomitic granular calcite limestone.

\section{STRUCTURE EXPOSED AT THE QUARRIES.}

Next in importance if not of equal importance to the petrographic problem in the lime industry of this region is the structural problem. The nature of this problem is shown by the following descriptions of the structure at some of the quarries:

\section{WEST STOCKBRIDGE.}

New England Lime Co.'s quarry.-The observed structure on the south wall and on the south side of the east wall, 100 feet from the south end, is shown in diagrams $A$ and $B$ of figure 15 , and the inferred general structure in diagram ( $\therefore$. This consists of two anticlines alternating with two synclines, all greatly overturned to the

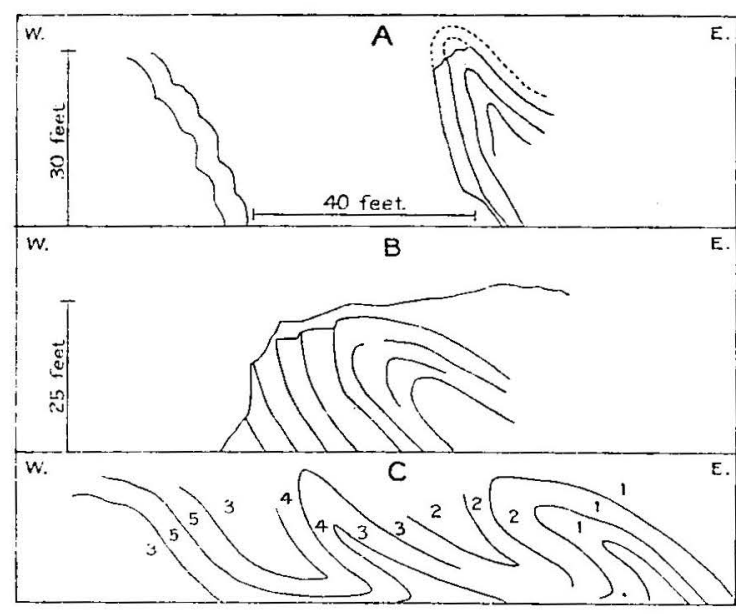

Figure 15.-Structure at New England Iime Co.'s quarry, West Stockbridge, Mass. A, Relations at south end; B, structure on east wall in south part; $\mathrm{C}$, inferred general structure. west-that is, with eastward-dipping axial planes. The practical effect of such a structure is that along an east and west cut an underlying series of beds, which here includes a considerable variety of limerocks, recurs three times, and an overlying series five times. There are 10 varieties of limerock in this quarry, including those that are discarded.

C. I. Miller quarrics.The general structure in these quarries is that of a flat-bottomed syncline with west limb dipping $30^{\circ}-40^{\circ}$ and an almost vertical east limb with sharp anticline on the east as shown in diagram B, figure 16 . A bed of schist, about 45 feet thick, underlies the quarried series on the west and is in turn underlain by several feet of white calcite marble. Whether this is a strip of overlying Berkslire schist misplaced by faulting or a schist lens in the Stockbridge limestone due to clayey sedimentation of purely local character could not be determined, but schist does occur rarely within the limestone. This schist is black, hard, heavy, and plicated. In thin section it consists, in descending order of abundance, of quartz, fibrous muscovite, biotite, graphite, chlorite, a little calcite, very few garnets, and some twinned albite feldspars with included graphite parallel to the schist bedding. The contact phenomena are shown in Plate $\mathrm{V}, A$. 
The east part of the same quarry or the central opening is shown in Plate VI, $B$, and some details as to the composition of the lower 40 to 45 feet of the limestone are shown in diagram $A$ of figure 16. The east opening and the steep east limb of the syncline are shown in Plate VI, $A$. Traces of the anticline cut by the quarry appear on the east wall.

Tobey Lime quarry.-The structure is less com plex than that at either of the quarries above described. There is a sharp syncline passing through the center of the quarry, double at the south end, with an anticline east of it and another west of it. The dolomite at the railroad underlies a coarse calcite marble with a dip of $60^{\circ} \mathrm{E}$. and forms part of a second syncline. The probable structure is shown in figure 17.

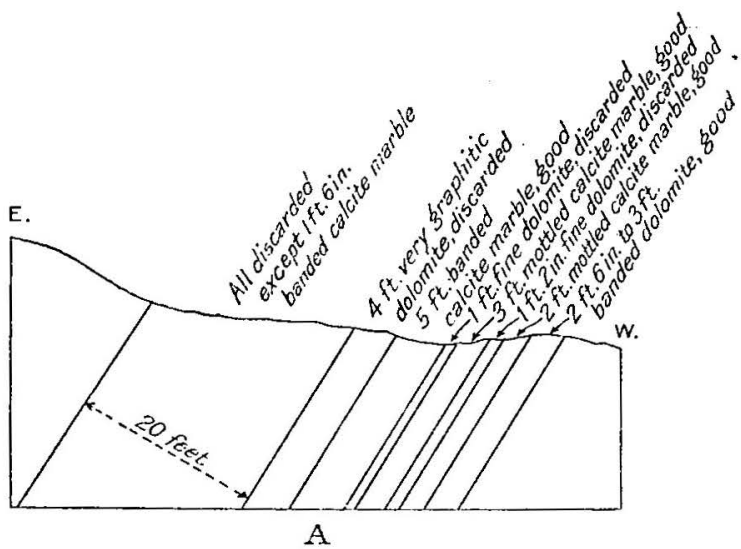

$E$.

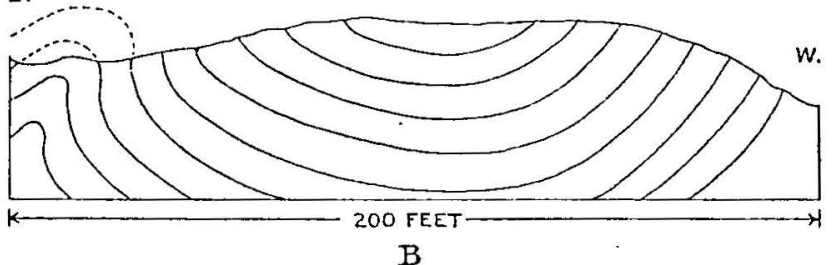

Figure 10,-Structure at the C. L. Miller quarries, West Stockbridge, Mass. $A$, Details in west opening; $B$, inferred general structure between east and west openings.

rucsdell quar (south). -A t the large abandoned

quarries at the sonth end of the village the two limestones are interbedded as shown in figure 18. Only 20 feet of the lower dolomite is exposed, and this contains a bed of calcite marble 4 to 12 inches thick. The specimens minutely described on page 51 came from the upper contact of dolomite. The strike of all these beds is $\mathrm{N} .75^{\circ} \mathrm{W}$. and the dip

W.

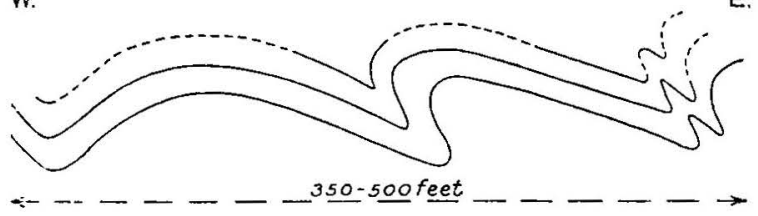

Figune 17,-llypolhetical structure at Tobey Lime quarry, West Stockbridge, Mass.
E. $40^{\circ} \mathrm{N} .15^{\circ} \mathrm{E}$., but a quarter of a mile N. $60^{\circ} \mathrm{W}$. is another old quarry with a calcite marble anticline striking about north.

Truesdell quarry (nor $(h)$. -This quarry is small and abandoned. $A$ compressed anticline, consisting of a central bed

of dolomite, originally about 14 inches thick but doubled on itself, with calcite marble on both sides, has an eastward-dipping axial plane, as shown in Plate V, $B$. Thin sections of both rocks are described on page 51. An analysis of the dolomite is given on page 35 .

General structure of the West Stockbridge Falley.-.The structural observations at and about the quarries afford an approximately correct idea of the geveral structure of the 
West Stockbridge Valley. The presence of the schist lens, necessarily syuclinal in structure, in the west half of the valley indicates a syncline in the underlying marble.

In other words, the marble beds exposed in the Tobey and Miller quarries west of the lens must turn to pass under the lens and but for the glacial deposits would reappear just east of the schist. The dolomite prong west of the quarried calcite rock, unless cut by a longitudinal fault, must represent a small anticline, probably overturned to the west projecting through the eroded calcite marble. At the Tobey quarry the dolomite dips under the marble, as it does also in the extreme southeast part of the dolomite area at the Rockdale quarry. The syncline exposed in the Miller

S.

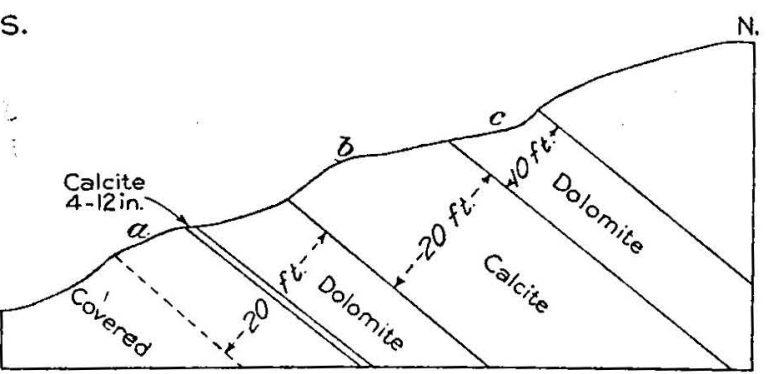

FigURE 18.--Structure at Truestell quarry (south), West Stochbrikge, Mass. showing interbedding of twinned calcite marble and granular dolomite. Bed $B$ contains at least ono small bed of dolomite. quarries (fig. 16, B) requires an anticline between it and the syncline of the schist lens and also an anticline on the west as the northern continuation of the dolomite prong. The bodies of calcite marble between the central dolomite of the valley and the schist masses of West Stockbridge

Mountain and Maple Hill all consist of minor folds. Their complex character is shown in the New England Lime Co.'s quarry (fig. 15, C) and by the anticline back of the West Stockbridge Marble Works quarry (fig. 23) and that in the Truesdell quarry, north (PI. V, B).

There are also other complications. While the normal strike of the region is north to northeast, some abnormal strikes appear. It the south Truesdell quarry the strike is $\mathrm{N} .75^{\circ} \mathrm{W}$. At locality 170 , on the Hastings farm, it is $\mathrm{N}$. $55^{\circ} \mathrm{W}$. In the central part of the dolomite area strikes of $\mathrm{N}$. $20^{\circ}-35^{\circ} \mathrm{W}$. are rather persistent, as sliown on the map (Pl. II).

\section{SHEFFIELD.}

Goodale quarry.--This quarry shows three groups of beds, the lowest of which is a coarse calcite marble with curved twinning planes, formerly quarried for construction but reported as unsound and also discarded in the manufacture of lime on account of

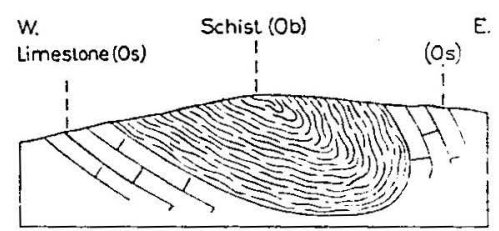

$+\ldots-\ldots-\ldots$ bogregt ....... - I proxinute structure at Masiach its coarseness. Its thickness has been reported as about 100 feet. Next above is a mottled white calcite marble, 20 feet thick, used by the Berkshire Hills Lime (io. for finishing lime. The uppermost group consists of alternating gray and white calcite marble, in all over 50 feet thick, some of which is used by the company for "common lime." The general strike is N. $10^{\circ}-20^{\circ} \mathrm{W}$., and the dip about $30^{\circ} \mathrm{E}$. There is a minor anticline in the lowest bed where it reaches the surface.

Massachusetts Lime Co.'s quarries.--Although these quarries are abandoned, they offer structural and petrographic features of economic interest. The location and geologic relations are shown on Plate III, and the approximate structure is given in figure 19. The calcitic beds quarried included the upper 135 feet of the Stockbridge imestone immediately under a remnant of Berkshire schist. One opening was 
made on the east side of a narrow eastward-pitching syncline of schist, where the schist dips steeply under the marble, and another opening or several were made on the west side of the syncline, where the marble dips under the schist as shown in figure 19. The variation in the mineral composition of the beds is very great. Some are very quartzose; one was very pyritiferous with some l-inch cubes; some are quartzose and pyritiferous (specimen $48, \mathrm{~b}, \mathrm{p} .26$ ); another is dolomitic, quartzose, pyritilerous, and micaceous (specimen 48, h, p. 26); another is made up of alternating little beds of calcite and dolomite. Changes in the composition of the beds occur every few feet across the strike. The percentage of discarded rock at these quarries must have been very large.

\section{ADAMS.}

New England Lime Co.'s Renfrew quarry.-The structure is more distinct on the south wall than on the north wall. There are two synclines, the west one of which is close with vertical axis, and the east one more open but also vertical, as shown in figure 20. There appears to be a fault between the two synclines cutting out the

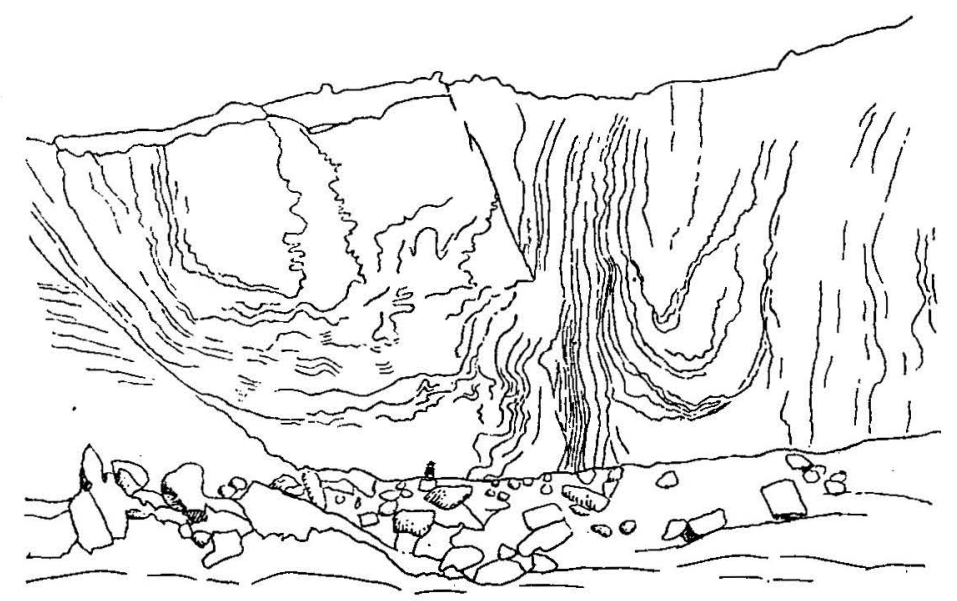

Figure 20.-Structure on south wall of Renfrew quarry of New England Lime Co., Adams, Mass., showing a compressed vertical syncline on the west with a more open one east of it. The anticline, which should intervene, has been shored upward and eroded. Part of the fault plane along which the movement occurred is risible in upper part of wall. From a photograph.

intervening anticline. The probability of a fault at this point was also inferred in 1899 from an examination of the south face as it then was. As the rock is in small. beds, indicating the possibility of frequent changes in the character of the material, and as the structure involves a fourfold repetition of the same series of beds, the general result is variety of composition. If all the beds had identical composition, the complexity of structure would have no economic significance.

\section{CHESHIRE.}

Farnam Cheshire Lime Co.'s quarry.-The exceptional areal position of the dolomitic horizon near Farnam has been pointed out on page 5 and is shown on the map (Pl. I). The locations of both this quarry and that of the Cheshire Lime Co. differ from those of the Adams quarries in that they are technically in an inlier: that is, in a closed anticlinal area of calcitic limestone separated from the limestone of Hoosic Valley by a belt of schist. This forms a synclinal ridge that rises 300 to 400 feet above the limestone and has seriously affected the transportation problem. 
At first the stone was carted to the kiln at the railroad through a notch south of the ridge. Next the stone was delivered at the kiln by "carriers" over the schist ridge, but finally a tunnel, 2,250 feet long, was made through the schist to the quarry, and the stone was delivered at the kilns by mine cars. At the west end of the tunnel the strike of the marble is $\mathrm{N} .35^{\circ} \mathrm{W}$., the dip $25^{\circ} \mathrm{E}$., and the depth of the quarry 170 feet. But for the exceptional occurrence of the dolomite at the east foot of the ridge immediately under schist all the limestone beds quarried in the closed area would have been found between the railroad and the ridge.

\section{LEE.}

Lee Lime Co.'s quary.-The width of the southern quarry face from east to west is 350 feet. The structure of the central part of this face is complex, as shown by Plate VII. It seems to consist of a major syncline with eastward-dipping axis,

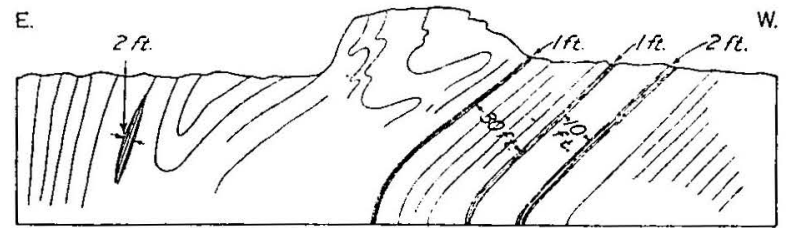

Figure 21.-Struetural detals in central part of south wall of Lee lime Co.'s quarry, Lee, Mass. The shaded beds are graphitic, more or less pyritiferous and tremolitic, and contain grains of granitic origin. another syncline east

w. of it, and a much elongated and compressed anticline between them. The east limb of a very wide anticline occupies the west hali of the quarry. The details of the central part are shown in figure 21. The dark beds occurring at intervals of 2,10 , and 30 feet include the tremolitic, micaceous, pyritiferous, and schistose rocks of specimens $179, \mathrm{~d}, \mathrm{e}, \mathrm{f}, \mathrm{g}$, described on pages $30-31$. The western part of the quarry is more free from these dark beds.

\section{ECONOMIC CONCLUSIONS.}

\section{SIGNIFICANCE OF AMOUNT OF DISCARDED IIMEROCK.}

As the cost of quarrying covers both usable and discarded rock the percentage of the discarded rock directly affects the cost of that which can be used. At one quarry the percentage of discarded rock to the whole amount quarried was reported as $7 \frac{1}{2}$, at another 40 . The need, therefore, is for a series of beds offering a minimum percentage of material unsuitable for lime. Where shall such beds be found? An important geologic principle bears directly upon this question.

With rare exception the character of marine sediments changes less along a series of beds than across them; that is, marine sediments deposited at the same time over a considerable area are likely to be more uniform than those deposited in the course of centuries at the same place. The greater the time represented the greater the possibility of changes in the sediments. Such changes are due to oceanic coastal currents, and to changes of level and of rainfall on the land, affecting the erosive power of rivers and thus the amount of sand and clay discharged by them into the sea.

It follows from the above principle that the amount of geologic time represented in the rocks of a quarry about 20 feet wide cutting 
across beds 200 feet thick is immensely greater than that represented in the rocks of a quarry cut 200 feet along a bed or beds 20 feet thick, and, of course, that the chances of a smaller percentage of discarded rock are altogether in favor of the second quarry.

In a series of small beds of such diverse character as those in many parts of western Massachusetts the difference in quarrying along the strike of a few good beds and of quarrying across a large number of beds might easily make a difference of 25 per cent in the amount of discarded rock.

SIGNIFICANCE OF GEOLOGIC STRUCTURE.

Generally the simpler geologic structure will afford the better quarrying conditions, and conversely the more complex structures the less favorable. Complex structure may also increase the percentage of rock to be discarded. If the beds are in close minor folds and the quarrying is done across them the evil of the variety of composition is repeated with each fold.

PROSPECTING FOR LIMEROCK IN THIS REGION.

Rational prospecting consists of two elements, the scientific and the mechnnical, neither of which alone is sufficient.

The first requisite is a reliable geologic map of the rock surface drawn upon a contour map of adequately large scale. Upon such a map the outcrops of calcitic and of dolomitic limestone should be located and the strike and dip of euch recorded. Each different bed exposed should be sampled, tested, and examined microscopically.

Specimens should be burned in a test kiln to determine whether the texture is so coarse or so fine as to cause rapid disintegration under fire or so fine as to result in rapid hydration after burning in an upright kiln.

Where the outcrops are inadequate to give a clue to the general structure trenches should be dug down to bedrock and in a direction at right angles to the strike.

After an area in which the natural and artificial exposures show the presence of a series of beds of suitable composition has been found the next step is to prognosticate the structure of the beds from the dip observations. Finally, if the structure proves to be simple, diamond core drilling should be done at several points in a line at right angles to the strike, and the cores should be as nearly as possible at right angles to the dip. The object of this work is to obtain a complete exhibit of the series of beds to be quarried. If necessary, parts of the cores can be studied microscopically or analyzed.

After all these preliminaries quarrying can be undertaken with a minimum of uncertainty as to its success. 
UTILIZATION OF THE GRANULAR DOLOMITES.

The granular and semigranular dolomites typical of the region have been fully described on pages 32-42. By comparing the nine analyses and the microdrawings and testing similar dolomites in test kilns their commercial value can easily be determined. Experiments to determine the effect of both slow and rapid heating should be tried, for these are known to operate differently; also to determine the effect of different temperatures, for dolomites do not require as high a temperature as calcite. It is possible that some of these dolomites can be burned only in a rotary kiln. Others, like specimen 143 , a (p. 34), are plainly too quartzose. Thus, the wide belt of granular dolomite exposed northeast and north-northeast of the Renfrew quarry in Adams has along its west edge several feet of quartzose dolomite quite unsuitable for lime, but the strip enst of that, as far as examined, contains very little silica.

\section{MAXIMUM GRADE OF TEXTURE FOR USE IN UPRIGHT KILNS.}

There seems to be $a$ difference in the practice of different firms in the rejection of marbles that disintegrate rapidly under fire. At the Hoosac Valley Lime Co.'s quarry (p. 25) calcite marble of texture grade 5 is discarded, but at the East Canaan quarry of the New England Lime Co., dolomite marble of grade 6 is used. It ought not to be difficult to establish by a series of test-kiln experiments and microscopic grain measurements just how coarse a marble should be discarded.

UTILIZATION OF THE GRANULAR CALCITIC LIMESTONE.

It is quite possible that such of the granular calcitic limestone as is without dolomite and is not too quartzose could be used for lime, but small beds and lenses of dolomite are so prevalent in this limestone and their dimensions vary so greatly that it would be impossible to make correct estimates of the percentage of high-magnesium rock which would be contained by the high-calcium rock of a quarry. (See Pl. VIII, $A$, and fig. 14.)

\section{SCIENTIFIC CONCLUSRONS.}

The purely scientific inductions from the stratigraphic and petrographic data collected during this economic investigation concern two subjects-the origin of dolomite in this region and the geologic history of the calcareous and adjacent beds. The first of these subjects interests geologists. The second ought to interest the more intelligent residents of the region, whether they are engaged in the lime industry or not. 
RELATIONS OF DOLOMITE AND CALCITE IN THE STOCKBRIDGE LIMESTONE AS BEARING UPON THE ORIGIN OF DOLOMITE.

\section{STRUCTURAI RELATIONS.}

The Stockbridge limestone consists of an upper calcitic series of beds and a lower dolomitic series, ${ }^{12}$ the areal relations of which are shown on the maps (Pls. I-IV). The dolomitic series consists in some places almost entirely of granular dolomite but in others, as south of Lee, largely of twinned dolomite and in Dover, N. Y., of both kinds. The calcitic series contains some beds of granular dolomite, as at the Truesdell quarries; in West Stockbridge (fig. 18 and Pl. V, $B$ ). This interbedding is also typical of the calcitic series in Vermont, ${ }^{13}$ where the beds of granular dolomite range from 18 inches to 100 feet or more in thickness. This interbedding of twinned calcite and granular dolomite may therefore be said to be characteristic of the calcitic upper part of the Stockbridge limestone in western Massachusetts and Vermont.

The granular calcite limestone in which the Stockbridge limestone merges along the Taconic Range presents still other phenomena, for granular dolomite is not only present in small beds but also in lenses small and large, as shown in Plate VIII, $A$, and figure 14, and in places as minute rhombs in the limestone.

The more intimate relations of the two rocks of this formation in Massachusetts are shown at several localities in Egremont, Lenox, West Stockbridge, Williamstown, and Sheffield, and in Connecticut at one in Salisbury. These localities are described briefly below.

At the contact of dolomite and calcitic marble on Baldwin Hill, in Egremont (PI. III), the dolomite is granular, of texture grade 1, and the marble consists of little beds of white twinned calcite of grade 2 alternating with little beds of graphitic twinned dolomite of grade 1.

At the Hutchinson quarry, in Lenox (see p. 12), a semigranular rusty-weathering dolomite of grades 1 to 2, consisting, as shown by Mr. Fairchild's analysis on face 41, of $\mathrm{CaCO}_{3} 53.50$ per cent, $\mathrm{MgCO} \mathrm{O}_{3} 37.26$ per cent, and $\mathrm{FeCO}_{3} 1.29$ per cent and containing a surplus of 10.09 per cent of $\mathrm{CaCO}_{3}$ above that of a normal dolomite, is interbedded with twinned calcite of grades 5 to 6 . The beds range mostly from 2 inches to sereral feet in thickness. The dolomite has grains of quartz, plagioclase and microcline feldspar, and scales of muscovite; the calcite of quartz and microcline. A specimen of the dolomite from a point near the calcite contains a bed, 0.2 inch thick, of calcite marble of grades 5 to 6 .

At the north Truesdell quarry in West Stockbridge a bed of light-gray granular dolomite of texture rade 0.1 and containing a little quartz and muscovite, originally 14 to 20 inches thick but now doubled on itself, is overlain by finely banded gray and white calcite marble over 12 feet thick, of grade 5 but containing some little beds of dolomite of grades 1 to 2 , including some twinned grains. The structure is shown in Plate $\mathrm{V}, B$. An analysis of the dolomite, given on page 35 , shows a deficiency of $? .61$ per rent of $\mathrm{Ca}^{\circ} \mathrm{O}_{3}$.

12 The results of a study of a large area of this limestone in Vermont are given in U.S. Geol. Survey Bull. 521, pp. 64-66, 1912.

"Idem, pp. 86-96. 
At the south Truesdell quarry, in West Stockbridge, granular dolomite and calcite marble are interbedded as shown in figure 18. The dolomite is a medium-gray granular rock with estimated average grain diameter of 0.036 to 0.05 millimeter, texture grades 0.1 to $\mathrm{I}$, and contains some grains of quartz and plagioclase feldspar, with minute muscovite. The calcite is of light-gray shade and estimated grain diameter 0.229 millimeter, grade 5 , and contains grains of quartz and plagioclase but less muscovite than the dolomite. The dolomite near its contact with the overlying calcite contains streaks of whitish twinned calcite, some but 1 millimeter thick, and the calcite, for at least $2 \frac{1}{2}$ inches from the dolomite, contains lenses and little beds up to 0.1 inch thick of gray granular dolomite. The central 20 -foot bed of calcite contains one or more small beds of dolomite, and the lower dolomite contains a 4 to 12 inch bed of calcite marble. A thin section across this contact shows twinned calcite, with estimated grain diameter of 0.35 millimeter, grade 5 . The granular dolomite is of estimated grain diameter 0.08 millimeter, grades 1 to 2 . It is quartzose, muscovitic, and sericitic, especially along the contact, and has rare grains of microcline and plagioclase feldspar.

At the Tobey Lime quarry in West Stockbridge a fragment from some bed in the calcitic series (specimen D, XXXIX, 125, d) consists at one end of white twinned calcite of estimated average grain diameter 0.16 millimeter, grade 4 , and at the other of medium-gray granular dolomite, estimated average grain diameter 0.035 millimeter, grade 0.1 , with muscovite and quartz along the contact. The two rocks are dovetailed into one another by plicated bedding. Another specimen (D, XXXIX, 125, c), from the same quarry but not traced to its bed, has circular to oval areas half to three-quarters of an inch in diameter on its surface which have weathered to a depth of 0.05 inch. The rock consists of irregular areas of twinned calcite of grades 4 to 5 , in a groundmass of untwinned grains, probably dolomite of grade 0.1 . At a point on the northwest foot of Mount Prospect, in Williamstown, on the 1,240-foot level and about 1,000 feet southwest of the sharp turn in the schist boundary, the dolomite underlies calcitic beds. The calcite, white, twinned, of grade 5 , is finely interbedded with grayish graphitic dolomite of grade 0.1 , the larger grains of which show typical dolomite twinning. At the abandoned Briggs marble quarry, in Sheffeld, a white twinned calcite marble (specimen $\mathrm{D}, \mathrm{XXXIX}, 18$, a) of estimated grain diameter 0.46 millimeter, grade 6 , in beds several feet thick, alternates with beds or lenses up to 2 feet thick of whitish granular dolomite (D, XXXIX, 18, c) of estimated average grain diameter 0.04 millimeter, grade 0.1 . It contains a few twinned grains (clouded with dark particles and possibly calcite) up to 0.3 millimeter, also grains of quartz and scales of pale-brown mica (phlogopite) that are conspicuous along the contact. The calcite also contains a few grains of quartz and microcline and one of granite or pegmatite. The following analysis of the dolomite was made by J. G. Fairchild, of this Survey:

Analysis of dolomite from the Briggs quarry, Sheffield, Hass. Insoluble in acid:

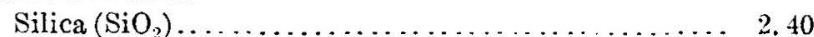

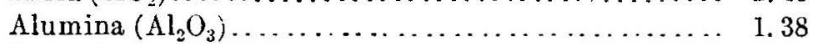

Soda $\left(\mathrm{Na}_{2} \mathrm{O}\right)$ and potash $\left(\mathrm{K}_{2} \mathrm{O}\right) \ldots \ldots \ldots \ldots \ldots \ldots \ldots, 1.22$

Soluble in acid:

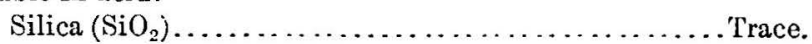

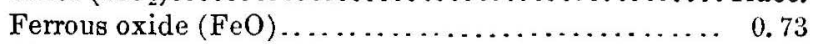

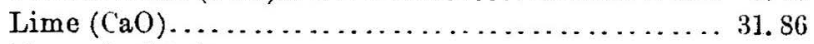

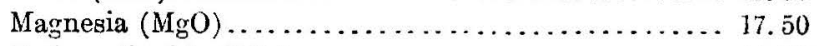

Carbon dioxide $\left(\mathrm{CO}_{2}\right) \ldots \ldots \ldots \ldots \ldots \ldots \ldots \ldots \ldots .44 .56$ 


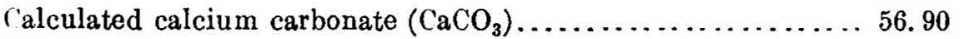

Calculated magnesium carbonate $\left(\mathrm{MgCO}_{3}\right) \ldots \ldots \ldots \ldots \ldots \ldots \ldots .58$

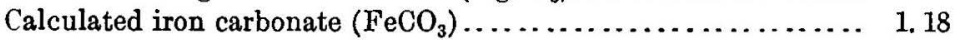

The insolubles indicate the presence of quartz, feldspar, and phlogopite. As the amount of $\mathrm{CaCO}_{3}$ required to form a normal dolomite with the calculated 36.58 per cent of $\mathrm{MgCO}_{3}$ is 42.57 per cent, this rock contains a surplus of 14.33 per cent of $\mathrm{CaCO}_{3}$.

INTERBEDDING OF TWINNED CALOITE (MARBLE) WITH GRANULAR DOLOMITE.

One of the striking features in the limestones of this region is the common interbedding of twinned calcite rock with granular dolomite in which the grains, although sufficiently crystalline to polarize light, do not show, with rare exceptions, either cleavage or twinning. (Compare figs. 2 and 22, with fig. 5.) As crystallization of limestones in such a metamorphic region is to be attributed chiefly and primarily to pressure rather than, as in unaltered fossiliferous crystalline limestones, to crystallization from solution, it may be assumed that the difference in the hardness of calcite (2.5 to 3.5$)$ and dolomite ( 3.5 to 4 ) would result in the development of cleavage and twinning in the calcite under a given moderate degree of pressure, while the dolomite grains would merely have their molecules arranged in crystalline order so as to polarize light. But wherever the pressure became sufficiently great the dolomite grains would also develop cleavage and twinning. In such porphyroid dolomites as that shown in figures 9,10 , and 11 it would be necessary to suppose that the large grains were formed first and crystallized, possibly from solution under exceptional conditions, and the small grains of the groundmass were formed later but under insufficient pressure to produce cleavage and twinning.

INTERBEDDING OF TWINNED CALCITE AND TWINNED DOLOMITE ROOK.

At a small building-stone quarry half a mile north-northwest of Salisbury village, Conn., on the east foot of the Taconic Range, east of Wachocastinook Creek, that supplied material for the village library, the series, beginning on the east and in descending order, consists of Berkshire schist, dipping east and forming the west limb of a syncline; calcite marble, medium grained, medium gray, pyritiferous, about 20 feet thick; calcite marble, coarse, white, 25 to 40 feet thick, dipping $45^{\circ} \mathrm{E}$. Under this is a mottled white and grayish marble, 10 to 20 feet and probably more thick, consisting of sharply plicated laminae, 0.1 to 0.3 inch thick, of white and dark-gray twinned calcite alternating with light-gray twinned dolomite, with a pitch of about $70^{\circ}$. The calcite grains have an estimated average grain diameter of 0.48 millimeters (grade 6), and the dolomite of 0.08 millimeter (grade 1 to 2). The plications have been greatly distorted and in places are so sharp as to resemble cylinders and in diagonal section to be mistaken 
for crinoid stems of dolomite with a central part of calcite, which could hardly occur. ${ }^{14} \quad A$ microdrawing of the Salisbury twinned calcite-dolomite marble is shown in figure 22 . This deposit of twinned calcite and dolomite in fine, alternating little beds resembles that of Amsden, in Weathersfield, Vt., in which the beds are from 0.1 to more than 1 inch wide, ${ }^{15}$ and the calcite beds are of grade 6 and the dolomite of grade 4 , but the rock contains metallic hematite and biotite (black mica), which after burning give the lime almost

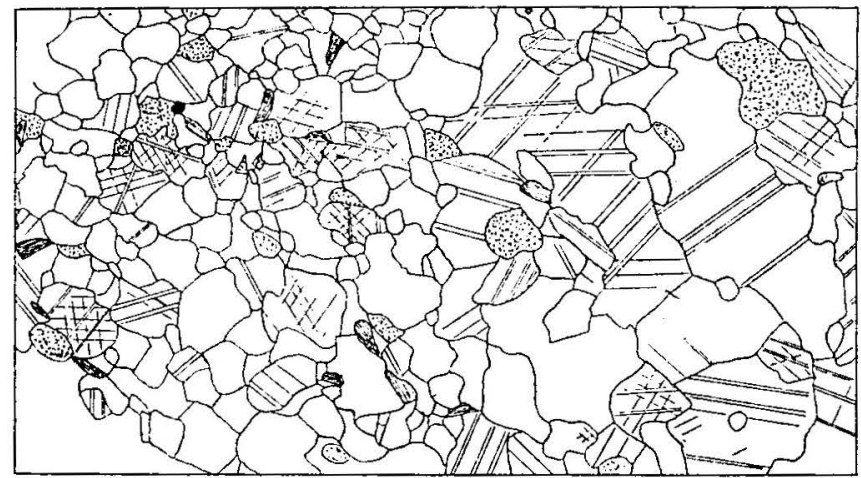

FIGURE 22.-Thin section of specimen from quarry near Salisbury, Conn. (D, XXXIX, 271, a), enlarged $27 \frac{1}{2}$ diameters, showing area of large grains of ealcite adjacent to aroa of small grains of dolomite, each with its typical twinning, in the calcite intersecting acute angle of cleavage rhomb, in the dolomite the obtuse angle. The dolomite contains some mus?ovite (linod grains) and quartz (dotted grains) and a little psrite (black).

the shade of cement. The combination of the two limestones was for many years found commercially advantageous.

\section{CONCLUSIONS.}

The general inferences from a study of these calcites and dolomites are as follows:

1. The usually greater abundance of mica and quartz in the granular dolomite near its contact with the twinned calcite beds, as at the Briggs quarry in Sheffield (p. 52) and near the Renfrew quarry in Adams (p. 5), indicates either the cessation or the beginning of some clastic sedimentation during the deposition of the dolomite. It is also noticeable at several points (Lee, p. 48; Monterey and Konkapot, p. 18; Dover, p. 20) that clastic sediments-that is, grains of quartz and feldspar, besides the constituents of mica and tremolite-reached the sea bottom at frequent intervals during the deposition of the dolomite of Horizon II.

14 See U. S. Geol. Survey Bull, 521, p. 33, 1912, where is given a description of crinoid stems from Isle la Motte, Vt., in which the stems are calcite and the groundmass dolomite in rhombs.

Is See U. S. Geol. Survey Bull. 589, pp. 32-34, 1915. 
2. The crystalline character of the interbedded calcite and dolomite varies considerably. Along the Taconic Range, in the dolomitic belt of the Stockbridge limestone, the calcite and dolomite are both granular, but east of that belt the calcite is always twinned and the dolomite where interbedded with it is always finer grained and may be granular, semigranular, or as near Salisbury, Conn., twinned. In Jamaica, Vt., a calcite marble of grade 5 is interbedded with twinned dolomite (marble) of grade $2 .{ }^{10}$ Where the two rocks are interbedded and the calcite is twinned it seems to be always coarser than the dolomite, but where neither of the minerals is twinned the dolomite seems to be coarser grained than the calcite, as in figure 14. The occurrence of areas of twinned dolomite in proximity to areas of granular dolomite, as in Lee and Dover, may be attributed to inequality of pressure during metamorphism.

3. The lenses of dolomite in the granular calcite, referred to on pages 9 and 43 and shown in figure 1 and Plate VIII, $A$, indi: ate the probably simultaneous occurrence of two very different processes of sedimentation within small spaces. Possibly some concretionary action not shown in the rock may have concentrated the $\mathrm{MgCO}_{3}$ (dolomite) into lenses on the sea bottom as rapidly as precipitated.

4. The analyses lead to the following inductions: Nine out of ten dolomites analyzed show a surplus of $\mathrm{CaCO}_{3}$ ranging from 2.43 to 12.96 per cent above that required for a normal dolomite. The dolomite limestone (specimen 124, a, p. 28) is about 59 per cent dolomite and 41 per cent calcite, both dolomitic and calcitic deposition having probably been simultaneous, as the grains of both are irregularly distributed. After excluding the $\mathrm{CaO}, \mathrm{CO}_{2}$, and $\mathrm{MgO}$ (from the solubles) in the 11 analyses of dolomites the remaining compounds range from 0.69 to 14.23 . Leaving out specimen 143 , a, on account of its exceptionally large content of $\mathrm{SiO}_{2}$, we find that the remaining 10 average 3.64 per cent. This percentage represents $\mathrm{SiO}_{2}, \mathrm{FeO}, \mathrm{Fe}_{2} \mathrm{O}_{3}$, $\mathrm{Al}_{2} \mathrm{O}_{3}, \mathrm{P}_{2} \mathrm{O}_{5}, \mathrm{Na}_{2} \mathrm{O}, \mathrm{K}_{2} \mathrm{O}$, and $\mathrm{TiO}_{2}$ present in the quartz, feldspars, micas, tremolite, pyrite (the $\mathrm{S}$ of which was not determined), siderite $\left(\mathrm{FeCO}_{3}\right)$, for which a very slight reduction of the figure for $\mathrm{CO}_{2}$ would have to be made, and finally rutile and apatite in infinitesimal quantities.

5. The transition between granular dolomite and twinned calcite at the south Truesdell quarry and at the Tobey quarry in West Stockbridge (p. 52) does not point to the alteration of calcite to dolomite but to a gradual change from one kind of sediment to another, with an overlapping in time of the deposition of both kinds at the beginning and end of the change. The fine interbedding of both twinned dolomite and calcite near Salisbury (p. 53) is more easily explained by an alternation of different sediments than by the dolomitization

10 T. S, Geol. Survey Bull. 589, pp. 37, 39, specimens $73, a, b$. 
of every other small bed of calcitic sediment. The general subject of the interbedding of calcite and dolomite and the origin of dolomite has been discussed in an earlier report, ${ }^{17}$ in which it was shown that the presence of exceedingly fine beds of granular dolomite in massive strata of twinned calcite is more easily explained by difference in sedimentation than by dolomitization. The most conclusive fact, however, is the occurrence at the base of the Stockbridge limestone in West Clarendon, Vt., of a bed about 25 feet thick of graphitic dolomite, in places of coarse oolitic texture, the nodules being from 0.1 to 1.1 inches in diameter, each formed about a more or less complete pteropod shell, partly filled with quartz. As thin sections fail to show any traces of organic texture in the nodules the presumption is that they are concretionary and due to chemically precipitated dolomite. ${ }^{18}$

\section{WESTWARD CHANGE FROM CALCITE MARBLE TO GRANULAR LIMESTONE IN BEDS OF THE SAME FORMATION.}

The change from twinned grains of calcite, constituting a marble, to polarizing but not twinned grains, making a granular limestone, occurs between Stockbridge, Mass., and Canaan, N. Y. (PI. II), and again near South Williamstown (Pl. I). It is probably due to the same diminished crustal pressure to which is attributed the general decrease of metamorphism westward from the central axis of crystalline rocks of the Green Mountain Range. That decrease of metamorphism is well shown in the townships of Pawlet and Rupert, Vt., where there is a gradual transition from the typical highly metamorphic Berkshire schist (Horizon IV) on the east to unaltered shales and grits on the west. ${ }^{19}$ This decrease of metamorphism westward in the lime belt is also shown in the change from the dolomite shown in figure 5 to those in figures 6 and 7 , in which the original rhombic outline of some of the grains is still preserved.

\section{GENERAL HISTORY OF THE IIMESTONE DEPOSITS OF THIS REGION.}

The limestone beds are underlain by beds of quartzite or of micaceous and feldspathic quartzite of Lower Cambrian age which were originally beds of quartz sand or of such sand mixed with clay. These underlying beds are exposed on Monument Mountain, in Great Barrington, and on Rattlesnake Hill, in Stockbridge. These sands and clays were brought into the sea from granitic surfaces east of the Berkshire valleys. Upon these mechanical sediments were deposited

\footnotetext{
17 U. S. Geol. Sirrey Buli. 521, pp. 29-3j, 1912.

18 See U. S. Geol. Survey Fourteenth Ann. Rept., pt. 2, p. 534, fig. 51, 1894. The word "limestone" under the figure should read "dolomite." Sce also National Muscum specimens D, VIII, 292, a, 1, ctc.: including large polished one.

19 See Dale, T. N., and others, Slate in the Cnited States: C. S. Geol. Survey Bull. 586, 1. 123, 1914, also NIneteenth Ann. Rept., pt. 3, map, pl. 13, 1899.
} 
beds of the dolomitic series, the origin of which has been discussed in the previous section; and upon the dolomitic serjes those of the calcitic series, which were very largely of organic origin. The calcite represents mostly the lime extracted by marine organisms from sea water for the formation of their protective skeletons. In tracing the marble beds northward to Lake Champlain they are found to pass gradually into unaltered limestones abounding in marine fossils and conveying some idea of the original condition of the calcitic marbles. These fossils include gastropods, brachiopods, cephalopods, crinoids, etc., and marine plants. It is not necessary to go as far as Lake Champlain, for fossils begin to appear in the granular limestone of Canaan and Hoosick, N. Y.

Attention was called to the abnormal relations of the dolomitic beds to the calcitic beds in the townships of Cheshire and Lanesboro (Pl. I and p. 5) and also in Stockbridge southwest of the village (Pl. II), which recur along the foot of the Taconic Range northwest of the village of Williamstown. The same relations occur in Dutchess County, N.Y., in the townships of Dover and Pawling, along the foot of the schist range west of the valley (Pl. IV). From Dover Furnace southward for 2 miles or more the calcite marble adjoins the schist, but for 5 miles south of a point west of Wingdale station the dolomite takes the place of the calcite.

This relation may be explained in two ways. (1) Dolomitic sedimentation continued in some parts of the sea while calcitic sedimentation went on in adjoining areas. The same thing occurred on a large scale that took place on a small one in the beds sketched in figure 1 (p. 9). (2) There was an elevation of the sea bottom in places at the end of Stockbridge limestone time, so that part of the calcitic beds (Horizon III) were eroded and the surface of some of the dolomitic beds (Horizon II) became exposed. When these areas were resubmerged the clays, which under metamorphism later became schist (Horizon IV), were deposited in some places upon dolomite but in others upon the calcitic beds. The latter interpretation receives a little support from the discovery of pebbles of calcite marble in the lower part of the Berkshire schist in Adams, showing that in that vicinity the Stockbridge limestone must have been above water during the deposition of the lower part of the material of the schist. ${ }^{20}$

During the deposition of the calcitic series dolomitic sedimentation took place at irregular intervals of time and space, thus accounting for the presence here and there of the dolomite both near the top of the calcitic series and also within it. The thickness of all these dolomitic and calcitic sediments aggregates about 1,350 feet. They are of Cambrian and Ordovician age.

20 Dale, T. N., Local unconformity between the Berkshire schist and the Stockbridge limestone in Adams, Mass.: Am. Jour. Sci , 4th ser., vol. 49, p. 369, 1920. 
During Middle and Upper Ordovician time calcareous sedimentation throughout the Appalachian region largely ceased and the rivers brought fine clay and sand from the land masses on the east, completely covering the calcareous sediments to a depth of 2,000 to 2,500 feet, although this includes a few hundred feet of dolomitic and quartzose sediments. The cause of this widespread change must be sought in some change in the altitude of the land surface, which increased the erosive power of its streams.

At the end of Ordovician time all the rocks of the region studied, including those underlying and overlying the calcareous beds, were powerfully affected by crustal contraction, the effects of which were manifold: (1) The sea retreated westward. (2) Chemical and physical changes occurred in the sediments. The underlying sandstone passed into quartzite, and the clay beds into micaceous quartzite. The dolomite beds went into granular and twinned dolomite; the calcitic beds into calcite marble; the overlying clay beds into schist. Owing to a gradual decrease of the crustal pressure westward from the Green Mountain axis the marbles merged at the west in granular limestone. (3) All the beds became more or less intensely folded and plicated, according to the degree of their plasticity, and the axes of the folds ran north, north-northeast, or north-northwest, according to the direction of the compression. (4) Compressive and tensile stresses produced various systems of joints, which with the plicated beds became filled with quartz from siliceous solutions. (5) Under continued pressure at this time or possbily during the post-Carboniferous movement all the rocks were faulted both along and across the strike, and along the fault planes masses rode up with a vertical displacement as high as 1,500 feet, bringing beds of very different age to the same level, as at the north end of Monument Mountain, where the calcitic series and the schist are in contact with the micaceous quartzite on the south (Pl. II); and again in Sheffiold and Salisbury, where the schist is in contact with the dolomitic series (Pl. III).

The last important event in the history was erosion by atmospheric agencies and streams during the time that elapsed between the retreat of the sea and the advent of the continental glacier-that is, during the Silurian, Devonian, Carboniferous, Triassic, Jurassic, Cretaceous, and Tertiary periods. As the rocks are all in folds and the axes of the folds undulate vertically, the effect of erosion is to expose longish masses of the various series, more or less tapering at the ends, each of which represents either the trough or the arch part of a fold with a pitching axis. In places, as in Sheffield and Salisbury, erosion has left a lot of shreds of the sehist on the underlying calcitic series. In Stockbridge the protruding mass of micaceous quartzite forming Rattlesnake Hill must have been denuded of its original covering of dolomitic and calcitic limestone and schist-that is, of some 3,350 feet of beds. 
The amount of erosion effected by the continental glacier in its southeastward march across the region was slight compared to that of the long period of atmospheric erosion that preceded it. Of serious economic advantage and disadvantage, however, was the covering of large areas of limestone by glacial gravels and boulders or by the sands and clays from streams and lakes due to the thawing of the ice sheet or its damming of the original drainage.

\section{LIMESTONE FOR AGRICULTURAL USES.}

Limestone is quarried for direct agricultural use at the Granger quarry, about 1.6 miles south-southwest of West Stockbridge village, at the foot of Maple Hill. (See Pl. III.) This quarry is operated by the Granger Lime Co., of Boston, Mass. It is about 200 feet wide from north to south and cuts the beds at right angles to the strike. The dip is $40^{\circ} \mathrm{E}$., and there is no evidence of folding. The beds are calcitic, but some are dolomitic. None of them are coarse calcite marble. The rock is very finely powdered und is shipped in barrels.

Although the Hoosac Marble Co., of North Adams, disposes of most of its ground calcite marble for chemical uses, it also supplies "ground limestone" for agricultural uses. Its quarry is near the Natural Bridge, about $1 \frac{1}{4}$ miles northeast of the North Adams station.

These enterprises involve the much discussed question as to the relative advantage of the following two chemical and organic processes in agriculture: (1) Calcitic and dolomitic limestone $\left(\mathrm{CaCO}_{3}\right.$ and $\left(\mathrm{CaMg} \mathrm{CO}_{3}\right)$ in extremely fine particles, distributed in the soil, in course of time are either taken up by the organic acids of the root hairs or are made available to them after solution by the carbonic acid of rain water; but, what is of still greater importance, these limestones neutralize any excessive acidity in the soil. (2) Burned calcitic and dolomitic limestone $(\mathrm{CaO}$ and $\mathrm{MgO})$, hydrated or partly air slacked and distributed in the soil, become fully slacked by rain water-that is, they pass back into carbonates and thus are readily taken up by the root hairs, and they also neutralize any excessive acidity in the soil. ${ }^{21}$

The Hoosac Valley Lime Co., of Adams, has tried to solve the problem by supplying a mixture of one-half partly burned limestone and one-half partly slacked lime, with the idea that the partly burned limestone would be more easily dissolved by the carbonic and organic acids and also be less dangerously caustic.

In connection with this question it should be stated that it has been experimentally established that both calcium and magnesium

21 See the bulletins of the agricultural experiment stations of the States of Maryland, Massachusetts, New York, Ohio, Pennsylvania, Rhode Island, Tennessee, and Virginis. The question of the relative cost of the powdered and of the burned stone is considered in the discussion.

$$
\text { 21200-23-Bull. 744-5 }
$$


are indispensable elements in plant organisms and also that root hairs by their content of organic acids directly dissolve limestone. The writer has observed that different kinds of lichens grow on adjacent ledges of dolomite and of siliceous rock, some kinds evidently thriving better on the calcareous rock. Botanists always look for certain ferns on limestone ledges or boulders. Vermont sugar orchards situated in the midst of marble ledges are reported as yielding a slightly different kind of maple sugar from those growing on soil less abundantly supplied with limerock. But the quantity of calcium and magnesium needed by plants is infinitesimal compared to that required in the form of lime and magnesia to neutralize the acidity of certain soils.

\section{DOLOMITE AND CALCITE MARBLE QUARRIES.}

Although the marble industry in western Massachusetts is old, so far as that term can be applied to this country, it is now confined to two active quarries. ${ }^{22}$ In view of the possibility that some of the idle or abandoned quarries may be reopened either for constructional stone or for the production of lime the more important of them are briefly described below with the active quarries.

LEE.

Lee Marble Works quarry.-Operator, Lee Marble Works. The quarry is threeeighths of a mile $\mathrm{S} .15^{\circ} \mathrm{E}$. from Lee Church. The marble is white with some faintly bluish-gray streaks and in places with sparse clusters of radiate fibrous tremolite up to 0.8 inch in diameter. It consists of twinned grains of dolomite not markedly interlocking, 0.075 to 0.5 millimeter in diameter (exceptionally 1 and even 1.5 millimeters), with an estimated average of 0.146 millimeter of grade 4 (medium). It contains besides the tremolite very rare muscovite and very rare and minute pyrite. A recent compression test of this dolomite marble by the United States Bureau of Standards shows as the average of two tests on bed, 20,222 pounds per square inch; of two on edge, 18,413 pounds; general average, 19,317 pounds. Som . of the stone is unsuitable for polishing because of the presence of very minute cavities ("sand pits") containing decomposed dolomite. Some beds contain an objectionable abundance of tremolite crystals, the presence of which is brought out in weathering by the more ready solution of the dolomite about them. Such beds are avoided as far as possible in quarrying. The beds strike $\mathrm{N}$. $75^{\circ}-85^{\circ} \mathrm{W}$. and dip $15^{\circ} \mathrm{S}$. There are 140 feet of light beds underlain by gray beds of undetermined thickness. Most of the quarry is free from joints. One of the products of the quarry is headstones for the graves of soldiers in United States cemeteries. The epitaphs are cut in raised letters by attaching brass letters with roundish upper surfaces to the marble and exposing it to a sand blast long enough to remove the marble between the letters to a depth of a quarter of an inch. The sides of the letters are then sharpened with pneumatic hand tools. The following buildings have been made of the marble of this quarry: Philadelphia public buildings; Massachusetts State House Annex, Bos-

${ }_{22}$ For interesting facts in regard to the beginning; of the marble industry in Massachusetts, Connecticut, Vermont, and New York, see Seely, H. M., The marble fields and marble industry of western New England: Middlebury (Vt.) Hist. Son. Papers and Proc., vol. 1, pt. 2, pp. 23-\{8, 1885; Merrill, G. P. stones for building and decoration, 3d e.., New York, 1908. 
ton; New York City Clearing House, Metropolitan Life Insurance Co. Annex, New York; public library, New Rochelle, N. Y.; town hall, Milford, Conn.; public library, Lee, Mass.

White Marble \& Terrazzo quarry.-Operator, White Marble \& Terrazzo Co., Lee. The quarry is immediately south of the west half of the Lee Lime Co.'s quarry, or about seven-eighths of a mile S. $12^{\circ} \mathrm{W}$. from Lee Church. The marble is identical with the best from the Lee Co.'s quarry as described on page 29 , a faintly creamcolored ("white") dolomite of interlocking twinned grains of grades 3 (fine) to 4 (medium). The stone is used for building, tiling, terrazzo, and mosaic flooring. The greater hardness of dolomite than calcite makes dolomite marble well adapted for all kinds of flooring.

\section{WEST STOCKBRIDGE.}

West Slockbridge Marble Works quarry.-This quarry is said to have been operated in 1802 by Newell \& Cook and was operated recently by the West Stockbridge Marble Works but was idle in 1918. It ljes about 2 miles south-southwest of West Stockbridge village, at the east foot of a spur from Maple Hill, on the west bank of Housatonic River. This spur does not appear on the map, but its general outline is shown in figure 23 .

The marble, white calcite, is reported to have been used in part of the old city hall of New York. The beds strike N. $10^{\circ} \mathrm{E}$. and dip $60^{\circ} \mathrm{E}$. In ascending the spur

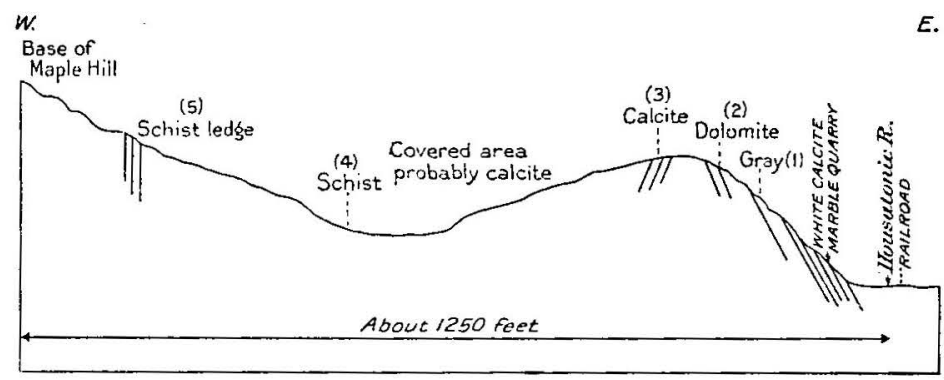

Figure 23.-Outline of surface and structural data of east foot of Maple Hill, West Stockbridge, Mass., showing probable marble area west of West Stockbridge Marble Works quarry.

from the quarry the following outcrops are met: (1) Gray calcite marble, dipping under the white; (2) near crest of spur, granular dolomite, also dipping eastward; (3) on slope toward the hollow, calcite marble, dipping $70^{\circ} \mathrm{W}$; (4) at foot of Maple Hill proper, where surface begins to rise, small schist outcrop; (5) about 400 feet farther west, line of schist ledges 30 feet high with plicated bedding vertical. (See fig. 23.) Inasmuch as the calcite marble of the Taconic region generally immediately underlies the schist, the probability is that the swampy hollow between outcrops 3 and 4 is underlain by marble. In view of the unfortunate location of the old quarry near the river an east-west trench should be dug from 3 to 4 down to the rock surface to determine the character of the beds. To judge from the dip of the schist on the west their dip will probably be found to be very steep. As the hollow slopes gradually south-southeastward toward the river it would only require a spur about one-third of a mile long to transport the stone to the railroad, and gravity might furnish the power.

Rockdale quarry.- This ancient quarry is on a bench on a small spur from West Stockbridge Mountain, 3 miles nearly south of West Stockbridge village and about 160 feet above the carriage road. It lies in the calcitic limestone area bordering the schist of that mountain, east of the dolomitic area that occupies the 
West Stockbridge valley. (See Pl. II.) The marble is white and gray calcite. The beds dip about $25^{\circ} \mathrm{E}$. and are exposed for a thickness of 30 to 40 feet, overlying granular dolomite.

\section{ALFORD.}

Gross quarries.-Once operated by the Alford Marble Co. but now abandoned. One of these quarries is reported to have been opened in 1803 by Johnson \& Stevens and to have also furnished marble for the old City Hall in New York. These quarries were formerly in West Stockbridge, but the town line was shifted. They lie at the west foot of Tom Ball Mountain, in the calcitic limestone belt between the schist on the east and the dolomite on the west. (See Pl. II.) At the northern opening the calcite marble is white and light gray banded. Its strike is $\mathrm{N} .25^{\circ} \mathrm{E}$. and its $\operatorname{dip} 40^{\circ} \mathrm{S}, 65^{\circ} \mathrm{E}$. At the southern opening the marble is white and gray in alternating bands, a quarter of an inch to 1 inch wide. The strike is about north and the dip $65^{\circ} \mathrm{E}$. The thickness exposed is about 80 feet. A bed face (or joint parallel to the bed) forming the east wall has slickensides dipping $5^{\circ}-10^{\circ} \mathrm{S}$. The marble on the west wall is underlain by 5 to 10 feet of white granular dolomite forming a small anticline. Its texture belongs in grade 1. It contains quartz, muscovite, and pyrite. Between the calcite marble and the dolomite is a transition bed consisting of grains of twinned calcite and sparse grains of cloudy dolomite, rarely a twinned grain.

Mann quarry. - This is the result of a more recent venture but is now abandoned. It is about south of the Gross quarries, on top of a conspicuous bench nearly 100 feet above the carriage road. The west slope of the bench consists of granular dolomite. The quarry is roughly 600 feet west of the schist boundary. The marble is white calcite with sparse small clouds. The grain diameter is 0.074 to 1.1 millimeters, estimated average 0.24 millimeter; grade 5 (coarse). It contains a little quartz, some of it probably secondary, muscovite, and pyrite. The clouds seem to be due to aggregations of these minerals. The beds strike $\mathrm{N} .10^{\circ}-15^{\circ} \mathrm{W}$. and $\operatorname{dip} 65^{\circ} \mathrm{E}$.

On the west side of the carriage road about southwest of this quarry is another abandoned marble quarry reported as once operated by the same firm. The rock is white twinned dolomite. On the east side of the road near by is a dolomite with coarse intense plications dipping west.

\section{EGREMONT.}

Joyce quarry.-This was operated in 1911 and later by the Egremont Marble Co. but was abandoned in or before 1918. It was reopened by a new company in 1920 but was idle in 1922. It lies about a quarter of a mile north of the west end of South Egremont village and 60 feet above it. The beds strike N. $10^{\circ} \mathrm{W}$. and $\operatorname{dip} 25^{\circ} \mathrm{E}$. The marble (specimens D, XXXIII, a, b, c) consists of more or less plicated minute beds of whitish twinned calcite 0.1 inch thick, alternating with dark-gray graphitic beds 0.04 inch thick. The grain diameter of the calcite of the whitish beds has an estimated average of 0.18 millimeter (grades 4 to 5 , medium to coarse). The grains of the dark beds have an estimated average diameter of 0.12 millimeter (grade 3 , fine). They do not appear to be dolomite, although the rock contains here and there nodules of dolomite and calcite.

\section{SHEFFIELD.}

Upson and Goodsell quarries and Hoskins prospect.-These ancient abandoned openings about 2 miles north-northwest of Sheffield village, are so nearly related, as shown on the map (P]. III), as to require common description. The two first, about a quarter of a mile apart, are on opposite sides of the geologic boundary, which near the southern quarry crosses the Hoskins farm, where both calcitic and dolomitic 
series are finely exposed and where in the calcitic series is a small opening. At the Goodsell quarry, on the east, the rock is white to cream-colored dolomite, semigranular to twinned, of grades 3 (fine) to 2 (very fine). The strike is N. $20^{\circ}-25^{\circ} \mathrm{W}$. and the $\operatorname{dip} 70^{\circ} \mathrm{N} .68^{\circ} \mathrm{E}$. The total thickness exposed is about 90 feet. At the Upson quarry, on the west, the rock is white calcite marble.

The prospect on the Hoskins farm is $\mathrm{N} .20^{\circ} \mathrm{W}$. of the Upson quarry, very nearly in line with the strike of its beds. The beds strike N. $25^{\circ} \mathrm{W}$. and dip $60^{\circ}-70^{\circ}$ $\mathrm{N} .65^{\circ} \mathrm{E}$. The marble is white calcite of medium to coarse texture. The thickness exposed appears to be about 170 feet. East of this marble is a covèred interval of about 300 feet followed by granular dolomite with the same strike and dip continuing eastward to a point near the Hoskins house, where it resembles the dolomite of the Goodsell quarry. Within the granular dolomite is a bed 15 to 20 feet thick of pinkish to buff calcite marble.

As the dips of both calcitic and dolomitic beds at these openings and outcrops are eastward and the dolomitic series is the lower, the tongue of calcitic limestone in which are the Goodale, Upson, and Hoskins openings must be synclinal in structure, and the apparent superposition of the dolomite series east of it is due to overturned folds. The structure may be illustrated by drawing a capital $U$ and a slightly smaller one inside of it and then tilting the diagram so that the $U$ would have its axis dipping to the right; that is, east. The lower letter would then represent the dolomite beds and the upper one the calcitic beds. The Goodale, Upson, and Hoskins openings would thus all be in the right limb of the upper $U$, but the Goodsell quarry and some of the beds near the Hoskins house would be in the right limb of the lower $U$.

As this locality affords both kinds of limerocks within easy access to the railroad it is well adapted for lime burning.

Briggs quarry.-This long-abandoned quarry is on the southeast side of an 80-foot knoll 21 miles a little north of west of Sheffield station. As shown on the map (Pl. III) it occurs in a necessarily synclinal southward-pointing tongue of calcitic limestone, but as there is a considerable area without outcrops south of the knoll the point of its termination is very uncertain. The rock is white calcite marble of grain diameter 0.185 to 1.85 millimeters with an estimated average diameter of 0.462 millimeter; grade 6 (extra coarse $A$ ). It contains a few small grains of quartz and feldspar and is interbedded with or incloses lenses up to 2 feet thick of light-gray fine granular dolomite (description and analysis on p. 52). The presence of this waste material must have added not a little to the cost of quarrying the marble.

Dresser quarry.-This is about $1 \frac{1}{2}$ miles west-northwest of Sheffield station and half a mile north of the east-west highway, in a wooded area (1918). It has long been abandoned. The marble (specimen $\mathrm{D}, \mathrm{XXXIX}, 17, \mathrm{a}$ ) is a glistening semigranular white dolomite with grain diameter 0.05 to 0.325 millimeter and estimated average 0.1 millimeter, grade 2 (very fine). It contains rare tremolite intergrown with dolomite, also a little muscovite, quartz, and feldspar.

Ashley Falls quarry. - This was operated from 1906 to about 1916 by the Ashley Falls Marble Co. but is now abandoned, and its buildings have been destroyed by fire. The quarry adjoins the railroad east of Ashley Falls station. The marble (specimens D, XXXIII, 1, a, b) is a white twinned dolomite and also a light bluishgray dolomite. The beds are nearly horizontal with a slight northwest dip; the white is 30 feet thick and the gray over 50 feet. Specimens of product: White, Bristol Trust Co.'s building, Bristol, Conn.; gray, Polish Catholic Church, New Britain, Conn. The company besides finishing its own stone finished blocks of Greek, Italian, and Norwegian marble obtained by rail from New York. 


\section{SOUTH DOVER, DUTCHESS COUNTY, N. Y.}

This quarry at locality 176, 2 miles northeast of Wingdale station (see Pl. IV), is operated by the South Dover Marble Co., of 133d Street and Walnut Avenue, New York City. The cutting plant is at Wingdaie station. The marble is a twinned dolomite of even texture and grain diameter 0.074 to 1.48 millimeters, estimated average 0.32 millimeter; grade 5 (coarse). It contains very little muscovite (possibly also phlogopite), pyrite, and quartz. The stone when first quarried has a slight bluish tinge but when dry is milk-white. The buildings erected of this marble include the Importers and Traders Bank and the Tiffany buildings in New York and the Essex County Courthouse in New Jersey. This quarry also supplied the interior of the New York Stock Exchange. The building of the National Academy of Sciences in Washington is being constructed of this marble. Experiments for the utilization of waste from this quarry in the lime industry should be undertaken.

\section{A SLIGHTLY DOLOMITIC GRANULAR LIMESTONE FROM BECRAFT MOUNTAIN, HUDSON, N. Y.}

During a hasty visit to the cement works on Becraft Mountain ${ }^{23}$ the writer obtained at the Portland Cement Co.'s Knickerbocker quarry a specimen (D, XL, 173, a) of Manlius (Silurian) limestone with the shelly flintlike fracture and fine homogeneous surface typical of some limestones. The following description of a thin section of this rock is given here on account of the contrast it offers to the granular calcite limestone of the belt of incipient metamorphism in the western part of the Taconic region shown in figures 13 and 14 .

The rock is of dark-gray shade with a slight brownish tinge. The surface would be perfectly homogeneous but for the presence of sparse lenses of crystalline calcite 0.1 to 0.2 inch long. In thin section it consists of irregular untwinned but polarizing grains of calcite, 0.0028 to 0.006 millimeter in diameter (estimated average 0.00337 millimeter), with very sparse dolomite rhombs up to 0.0427 millimeter in diameter. There are also many sections of rhizopod (?) shells, elliptical to spherical, 0.62 millimeter in diameter, filled with twinned calcite. The lenses seen on the surface consist of groups of twinned calcite grains, possibly fillings of rhizopod shells or other fossils. There are 'spherules of pyrite, the oxidation of which has disseminated a limonite stain, which accounts for the brownish tinge of the rock. There are also rare minute clastic grains of quartz.

An analysis of this stone, made for the company and furnished by the superintendent, shows $\mathrm{CaCO}_{3}$ (calcium carbonate) 86.4 per cent and $\mathrm{MgO}$ (magnesia) 1.55 per cent. The very small percentage of magnesia is thus corroborated by the presence of the sparse rhombs of dolomite shown by the microscope.

The writer has described a thin section of a very similar limestone from Alabama, ${ }^{24}$ the particles of which had the same dimensions. It

${ }^{23}$ The geology of this locality has been carefully studied by $\Lambda$. W. Grabau (Stratigraphy of Becraft Mountain, Columbia County, N. Y.: New York State Yus. Bull. 69, 1903).

1 U.S. Geol. Eurvey Bull. 521, p. 11, 1912. 
also contained minute rhombs of dolomite and sections of fossils. Both of these rocks belong to the same type of limestone void of any trace of metamorphism.

MARBLE TEXTURE.

The terms used in defining the texture in the preceding pages are set forth in the subjoined table.

Grades of marble texture.

\begin{tabular}{|c|c|c|c|c|c|}
\hline \multirow{3}{*}{ Grade. } & \multicolumn{4}{|c|}{ Grain diameter. } & \multirow{3}{*}{ Examples. } \\
\hline & \multirow{2}{*}{$\begin{array}{l}\text { Maxi- } \\
\text { mum by } \\
\text { microm- } \\
\text { eter (mil- } \\
\text { limeter). }\end{array}$} & \multirow{2}{*}{$\begin{array}{c}\text { General } \\
\text { extremes } \\
\text { by mi- } \\
\text { crometer } \\
\text { (millime- } \\
\text { ter). }\end{array}$} & \multicolumn{2}{|c|}{$\begin{array}{c}\text { Actual average } \\
\text { (Rosiwal method). }\end{array}$} & \\
\hline & & & $\begin{array}{l}\text { Millime- } \\
\text { ter. }\end{array}$ & Inch. & \\
\hline 0.1 . Extra fine $B .$. & 0.14 & $0.02-0.09$ & $\begin{array}{l}0.04 \text { and } \\
\text { under. }\end{array}$ & $\begin{array}{l}0.001 \text { and } \\
\text { under. }\end{array}$ & $\begin{array}{l}\text { Värra, Trondhjem, Norway; "white P," } \\
\text { Carrara, Italy; "dark blue," Marble } \\
\text { Island, Alaska; "light," Red Bay, } \\
\text { Prince of Wales Island, Alaska. }\end{array}$ \\
\hline 1. Fxtra fine A.... & .2 & $.0 .5-.1$ & .06 & .0023 & Dolomites, Swanton, Vt. \\
\hline $\begin{array}{l}\text { 2. Very fine } \ldots \ldots \ldots \\
\text { 3. Fine } \ldots \ldots \ldots \ldots \ldots\end{array}$ &.$\frac{5}{.5}$ & $.07-.16$ & .12 & .0039 & $\begin{array}{l}\text { "Statuary" Rutland, Vt. } \\
\text { Carrara, "ordinary" Italy; "Penteli- }\end{array}$ \\
\hline & & & & & $\begin{array}{l}\text { con," (ireece; "second statuary," Rut- } \\
\text { land, Vt.: "cream 1" and "Pentelic } \\
1, \text { (iantis Quarry Ala. }\end{array}$ \\
\hline 4. Medium........ & 1 & $.12-.31$ & .15 & .0059 & Dolomite, I ee, Mass. "Brandon Italian" \\
\hline 5. Coarse.......... & 1.5 & $.2-.6$ & .24 & .0091 & "Iaas statuary," Tyrol; "Iucidio,"," \\
\hline 6. Extra coarse A.. & 2.54 & $.3-1.35$ &.$j$ & .01913 & "Parian," Greece; some Norwegian; \\
\hline 7. Fxtra coarse B.. & 2.8 & $.50-1.96$ &.$\$ 4$ & .0331 & "Light,"' Prince of Wales Island, also \\
\hline $\begin{array}{l}\text { 8. Dou ble extra } \\
\text { coarse. }\end{array}$ & $5-7.62$ & $b 1.4-2.8$ & $1.24-1.55$ & $0.18-.059$ & $\begin{array}{l}\text { Sterzing, Tyrol; Tate, Ga.; "white," } \\
\text { Prince of Wales Jsland, also Ham Is- }\end{array}$ \\
\hline 9. Coarsest......... & c 18 & & $d \pm .6$ & d. 166 & Texas; Baltimore County, Md. \\
\hline
\end{tabular}

a The avcrage of seven Rosiwal measurements on thin sections, four across the bed and three with it, made from three 2 -inch cubes, is 0.00915 inch, or 0.2326 millimet er.

$\checkmark$ These estimates refer only to marl le with a maximum of 5 millimeters.

c Measured on blocks in base of Washington Monument in the Capital. Maximum 0.7 inch.

d Estimated nverage.

\section{GLOSSARY OF SCIENTIFIC TERMS.}

Anticline.--The areh part of a wavelike bed of rock.

Bed. $-A$ continuous mass of material (sediment) deposited under water at about one time.

Biotite. $-\Lambda$ brownish to black mica containing a considerable percentage of iron and magnesia.

Brachiopoda.-Small marine animals, generally with a bivalve shell and provided with two ribbon-like respiratory organs near the mouth, which also serve to draw currents of water to the mouth.

Cephalopoda.-The most highly organized of the mollusks, represented by the modern nautilus, squid, and cuttlefish but in the early geologic periods by many species with coiled or straight shells having compartments for air or gas and serving to float the mollusk.

Clastic.-Made up of rocks or minerals which are fragments derived from other rocks. 
Crinoids.-Marine animals related to starfish and sea urchins but mostly with plantlike calcareous skeletons rooted and provided with an articulated stem bearing a cup contaîning the alimentary organs.

Crystalline.- When the molecules of a mineral are arranged in geometric order the mineral is said to be crystalline.

Dip.-The degree and the direction of the inclination of a bed, joint, etc.

Drift.-Sand and boulders deposited by a glacier, continental or local.

Erosion.-The wear of a rock surface by natural, mechanical, or chemical agencies.

Fault.-A fracture resulting in the dislocation of the bedding or other planes or vein of a rock, one part sliding up or down or laterally, or both changing positions along the fracture.

Fold.-Term used to describe the form which a rock mass assumes in consequence of lateral compression. Where the rock is very rigid faults may occur instead of folds, or the folds under continued compression may issue in faults.

Formation. - A group of beds possessing some common general characteristics or fossil forms differing from those of the beds above and below.

Gastropoda. - A group of mollusks including land, fresh-water, and marine snails.

Geometric analysis. - A method of determining the approximate percentages of the mineral constituents of a rock which consists of adding together the diameters of all the particles of each mineral measured on lines drawn on a polished face or projected on a thin section under the microscope. The percentage of the total diameters of each mineral on the total length of the lines gives the percentage of the mineral.

Grain elongation.--In rock undergoing erystallization under pressure the grains grow mostly in a direction at a considerable angle to the direction of pressure.

Granular.-Term applied to the texture of a sedimentary rock consisting entirely of irregular mineral grains and not crystals.

Horizon.-Term used to denote beds of the same geologic age.

Inlier--Minor portion of an area of rock exposed at the surface in consequence of the erosion of the overlying rock. This is sometimes called a "fenster," or "window," as the rock has only become visible through an opening in the overlying mass.

Lamina.-Term used in the study of rocks to describe a thin bladelike mineral or aggregation of minerals.

Metamorphic.-Term applied to a rock which has undergone metamorphism, a process, partly physical, partly chemical, by which the molecular structure of its constituent minerals and often the arrangement of its particles have been altered. If the cause of the process is a general crustal movement the metamorphism is said to be regional or dynamic, but if its cause is mainly the contact with a molten intrusive rock, it is called contact metamorphism.

Millimeter.-French decimal linear measure. The thousandth part of a meter or the tenth part of a centimeter. It is equivalent to 0.03937 inch, the meter being 39.37 inches.

Moraine.-The mass of sand, clay, gravel, and boulders deposited by a glacier.

Museovite.-Potash mica, the most common of the micas, generally of whitish to greenish color.

Orthopinacoid.- The name of two of the faces of a crystal of the monoclinic system that are parallel to both the horizontal and verticai axes.

Outlier.--An area of rock isolated from a not very distant larger mass of the same kind by the erosion of the intervening portion.

Petrographic.-Pertaining to the microscopic study of rocks.

Piteh.-The inclination of the axis of a fold of rock.

Porphyroid.-Resembling in texture a porphyry-that is, a rock congisting of isolated crystals in a general mass of finer particles. 
Quartzite.-A'metamorphosed quartz sandstone in which the cement that unites the quartz grains is also quartz.

Rhizopod.-An animal oi very low order and organization, consisting mainly of transparent jellylike protoplasm. Some rhizopods have a calcareous case. They abound in the ocean, and their remains form extensive oozes on the ocean floor.

Schist.-A crystalline rock made up of flattish particles arranged in rough parallelism, some or all of which have crystallized under pressure.

Slickensides.-The polished and grooved faces of a joint or bed caused by the motion and friction of adjacent rock masses.

Strike.-The direction at right angles to the inclination of a plane of bedding, joint, etc.

Syncline.-The trough part of a wavelike sheet or bed of rock.

Twinned crystals.-Crystals formed of two or more adjacent or intergrown crystals. In calcite and dolomite these adjacent crystals have the like poles of their main axis in opposite directions.

Unconformity.- When the lower of two contiguous deposits affords evidence of having been exposed to atmospheric erosion before the deposition of the upper one, there is said to be an unconformity between them.

Vein.-When correctly used, denotes a more or less irregular, sometimes ramifying mineral mass within a rock, occupying spaces produced by fracture or strain. 



\section{INDEX.}

Adams, Mass., descriptions of specimens from outcrops in.......... 35, 36, 40,41-42

distribution of ealcite and dolomite in... 4-5 structure exposed at quarry in........... 47 Agriculture, uses of limestone in.......... 59-60

Alford, Mass., distribution of calcite and dolomite in ......................

Alford Marble Co., Gross quarries of........

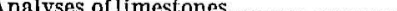

inductions from.

$30,32,33,34,35,40,41,42$

Anticline of dolomite and calcite, Truesdel quarry (north), plate showing...

Ashley Falls Marble Co., quarry of..........

Austerlitz, N. Y., distribution of calcite and dolomite in................. 14-15

Becket quadrangle, Mass., distribution of calcite and dolomite in ............10-14

map of ......................... In pocket.

Becraft Mountain, N. Y., description of limestone from................... 64-65

Berkshire, Mass., calcite and dolonite at....

Berkshire Hilis Lime Co.'s quarries, descriptions of rocks from..... 24, 25, 26, 27, 40

Berlin, N. Y., description of granular limestone in.................................

distribution of calcite and dolomite in...

Berlin quadrangle, Mass. and N. Y., distribution of calcite and dolomite in. ... 4-9

map of ......................... In pocket.

Briggs marblo quarry, Sheffield, Mass, description of

structural relations of ${ }^{2}$ alcite and dolo mite in ....................... 52-53

Calcite, granular, associated with granular dolonite................. $42-4$

granular, utilization of................ so

with nodules of granular dolomite, plate showing .................. 27

need for separale mapping of.......... 1

structural relations of, to the dolomite... $51-53$

Canaan, N. Y., deseription of specinen from outerop in.................. 36

distribution of calcite and dolomite in. . 14-15

Central calcitic belt in Sheffield and Sandisfield quadrangles, description of. . 16-17

Central dolomitic belt in Sheffield and sandisfield quadrangles, description of.

Cheshire, Mass., distribution of calcite and dolomite in................. $5-6$

structure exposed at quarry in........ $47-48$

Cheshire I,ime Co.'s quarry, deseriptions of rocks from.

Clastic sediments, deposition of.
Clove quadrangle, N. Y., calcitic areas in. dolomitic belt in.................... 10-21 general features of .................... 19 map of ...................... In pocket. Connecticut Lime Co.'s quarry, description of rock from.

Dalton, Mass., distribution of calcite and dolomite in ..................... 10-11

Deposition of the limestones, history of..... 56-59

Discarded rock, percentage of, influenced by direction of cut ............... 48-49

percentage of, influenced by structure of beds ..................... 49

Dolomite, even-textured, granular, descriptions of...................... 33-36 fine-grained, behavior of, in the kiln..... $31-32$ granular, associated with granular calcite. 42-44 availability of, for making lime..... $\quad 32$ utilization of ..................... 50 need for serarate mapping of........... 1 semigranular, deseriptions of .......... 40-42 structural relations of, to the calcite...... 51-53 uneven textured, granular, descriptions of ...................... $36,38-40$

Dover, N. Y., distribution of calcite in...... 21-23 distribution of dolomite in............... 19-21

Dresser marble quarry, Sheffield, Mass., description of .....................

Eastern dolomitic bolt in Sheffield and Sandisfleld quadrangles, description of.. 17-18

Egremont, Mass., calcite and dolonite in.... 15-16

descriptions of specimens from outcrops in 33 structural relations of calcite and dolomite in.

Egremont Marble Co., Joyce quarry of........ 62

Fairchild, J. G., analyses by..............27-28, $30,32,33,34,35,40,41,42$

Farnam Cheshire Lime Co.'s quarry, description of rock from ............... 24 structure exposed in................. 47-48

Geologic relations of the limestones......... 2-4 Glossary of terms...................... 65-67

Goodale quarry, structure exposed in....... 46 Goodsell marble quarry, Sheffield, Mass., description of.................. 62-63

Granger Lime Co., ground limestone for agriculture prepared by.

Graphite, effect of in finishing lime.......

Gravestones, marble, cutting of lettering on. $\quad 60$

Great Barrington, Mass., description of specimen from .....................

Greylock quadrangle, Mass., distribution of calcite and dolomite in ......... 4-9

man of...................... In pocket. 
Hancock, Mass., deseription of granular limostone in ..................... $+3-44$ distribution of calcite and dolomite in... $7-8$

Fillsdale, N. Y., description of specimen from outcrop in................ 36

distribution of calcite and dolomite in... 18-19

History of the deposition of the limestones... 56-59 Hoosac Marble Co., ground limestone for agricuiture prepared by.

Hoosac Tunnel, west portal, description of specimen from outcrop northwest

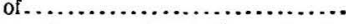

Hoosac Valley Lime Co., descriptions of rocks from quarries of ......... $24,25,26,27$

$\lim \theta$ for agriculture prepared by......... 59

Hoosick quadrangle, N. Y. and Vt., distribution of calcite and dolomite in... 9-10

Horizons I, II, and III, formations designated

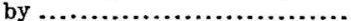

Hoskins marble prospect, Sheffield, Mass., description of................ 62-63

Hudson, N. Y., description of limestone from. 61-65

Interbedding of calcite and dolomite, explanation of ....................... 55-56

twinned calcite with granular dolomite.. $\quad 53$

twinned calcito with twinned dolomite. . 53-54

Kolley Island Lime \& Transport Co.'s quarries, descriptions of rocks from ................... 29-30,31-32

Kiln, choking of, by coarse-grained marble... 27 upright, maximum coarseness of rock usable in.

Lanesboro, Mass., distribution of calcite and dolomite in.

Lee, Mass., distribution of calcite and dolomite in....................... 13-14

structure exposed at quarry in......... 48

Lee Lime Co.'s quarry, descriptions of rocks from..................... 29, 30, 31

structure in south wall of .............. 48

plate showing..................... 26

Lee Marble Works, quarry of..............60-61

Lenox, Mass., descriptions of specimens from outcrops in .................. 35,41

distribution of ealcite and dolomite in... 11-12 structural relations of calcite and dolomite in.

Lenses of dolomite, possible origin of ......

Lime, finishing, calcitic rocks not making the best. calcitic rocks used for.............. 24 maganesian, dolomitic rocks not used for. 30-32 dolomitic rocks used for........... 2\&-30

Magnesia, effect of, in finishing lime........ 27 Maltby quarry, South Canaan, Conn., dcseription of rock from.........

Mann quarry, Alired, Mass., description of. Greylock and Berlin quadrangles, Mass. and $\mathrm{N} . \mathrm{Y} . \ldots \ldots \ldots \ldots \ldots$ In pocket.

Pittsfield and Beclset quadrangles, Mass. and $N, Y$.
Map of Sheffield and Sandisfiel dquadrangles, Mass., Conn., and N. Y.... In pocket. Marblc, calcite, westward change of......... 56 Marble quarries, descriptions of...........60-64 Massachussetts Lime Co.'s quarry, description of rock from .............. 26

structure exposed in................ 46-47

Mica, effect of, in magnesian lime.......... 30

Miller, C. L., quarries, descriptions of rocks from................ 24, 26, 27-28

plates showing..................... 26

structure exposed in..................44-45

Monterey, Mass., description of specimen from outcrop in.

New Ashford, Mass., distribution of calcite in. 6-7 New England Iime Co.'s quarries, descriptions of rocks from............. 24 $25,26,27,28-29,30$

structure exposed in ................ 44,47

New Lebanon, N. Y., distribution of calcite and dolomite in............... 1 1 15

North Adams, Mass., distribution of calcite and dolomite in .............. $4-5$

Pawling, N. Y., calcite in.................

dolomite in ........................... $20-21$

Petersburg, N. Y., distribution of calcite and dolomite in................. 9-10

Pittsfield, Mass., distribution of calcite and and dolomite in .............. 10-11

Pittsfield Lime \& Stone Co.'s quarry, description of rock from............. 24

Pittsfield quadranglo, Mass. and N. Y., distribution of calcite and dolomite

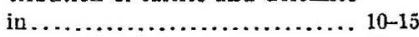

map of ............. In pocket. Pressure, incquality of, during metamorphism indicated............... 55

Prospecting, advice on ................... 49

Pyrite, effect of, in finishing lime....... 25, 26, 30

Pyritiferous dolomite, lime with black spherules from, plate showing........ 27

Quartz, effect of, in finishing lime ......... 25, 26

Reed, Charles, place, Great Barrington, Mass., deseription of specimen from..... 33

Richmond, Mass., description of specimen from outcrop in................ 36

distribution of calcite and dolomite in.... 11-12 Rockdale quarry, description of ..........61-62

Sandisfield quadrangle, Mass. and Conn., distribution of calcite and dolomite in...................... 15-19

map of .......................... In pocket.

Scope of the report...................... 1-2

Sheffield, Mass., descriptions of specimeus from outcrops in.............. 36, 40

marble quarries in.................... $62-63$

structure exposed at quarries in......... 46-47

Sheflield quadrangle, Mass., Conn., and N. Y., distribution of calcite and dolomite in................. 15-19

map of.............. In pocket. South Dover Marble Co., quarry and cutting plant of.................... 
South Williamstown, Mass., description of specimen from outerop in.........

Standard Lime Co.'s quarry, descriptions of rocks from.................. 29, 36

Stephentown, N. Y., distribution of calcite and dolomite in............... $8-9$ Stockbridge, Mass., description of specimen from outcrop in................ 40-41 distribution of calcite and dolomite in... 13-14 Structure of the limestones............... 44-48 influence of, on the percentage of discarded rock

Taconic Range calcite belt, description of... 15-16 Terms, definitions of................... 65-67 Texture, influence of, on behavior in kilns... 27,50 Texture of marbles, schedule of

Tobey Lime quarry, descriptions of rocks from.................... 24, 27

structural relations of calcite and dolo mite in

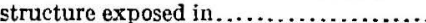

Page. Truesdell quarries, in magnesian lime....... cite and dolomite in........... 51-52 structure exposed in ................... 45 Truesdell quarry (north), anticline in, plate showing.................... 26 descriptions of rocks from............ $34-35,51$ Tyringham, Mass., distribution of calcite and dolomite in................. 12-13

Upson Marble quarry, Sheffield, Mass., deseription of..................62-63

West Stockbridge, Mass., descriptions of specimens from outcrops in... 33-35, 40 distribution of calcite and dolomite in... 12-13 structure exposed at quarries in ........ 44-46 West Stockbridge Marble Works, quarry of.. 61 Western dolomite belt in sheffield quadrangle, description of .

White Marble \& Terrazzo Co. quarry of .... Williamstown, Mass., distribution of calcite and dolomite in. age. 6 $-63$

40
46
17 61 7-8 


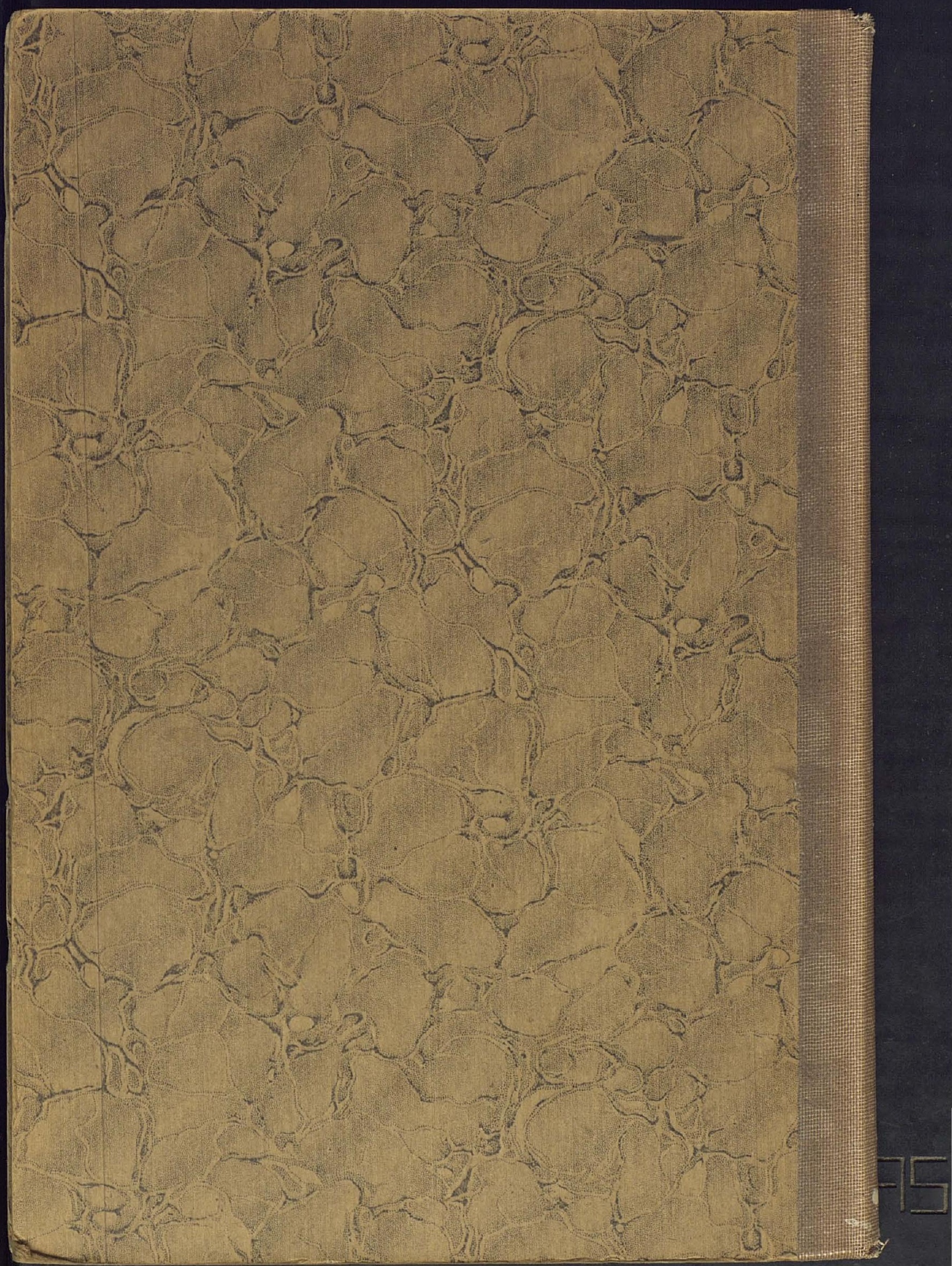




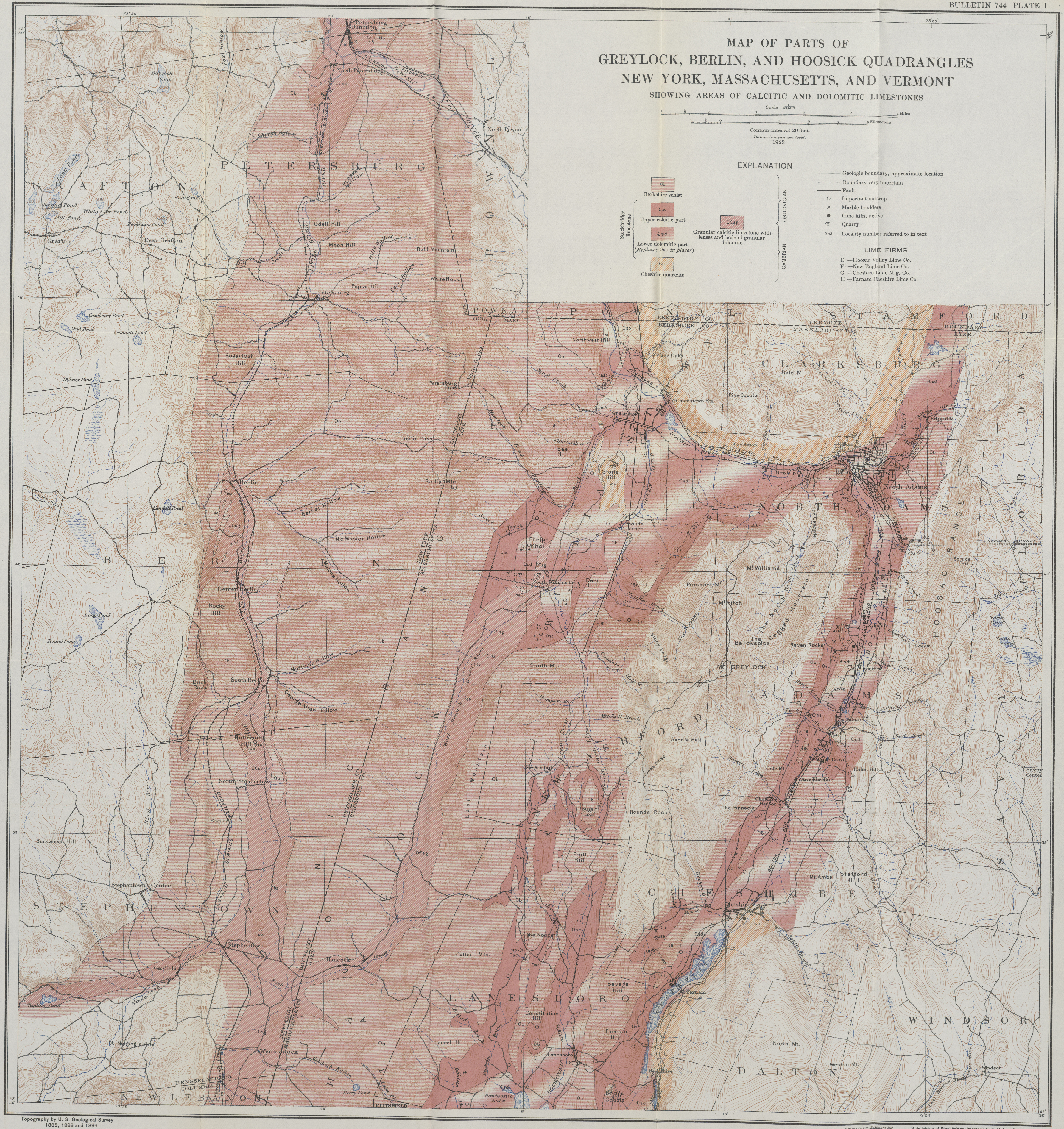




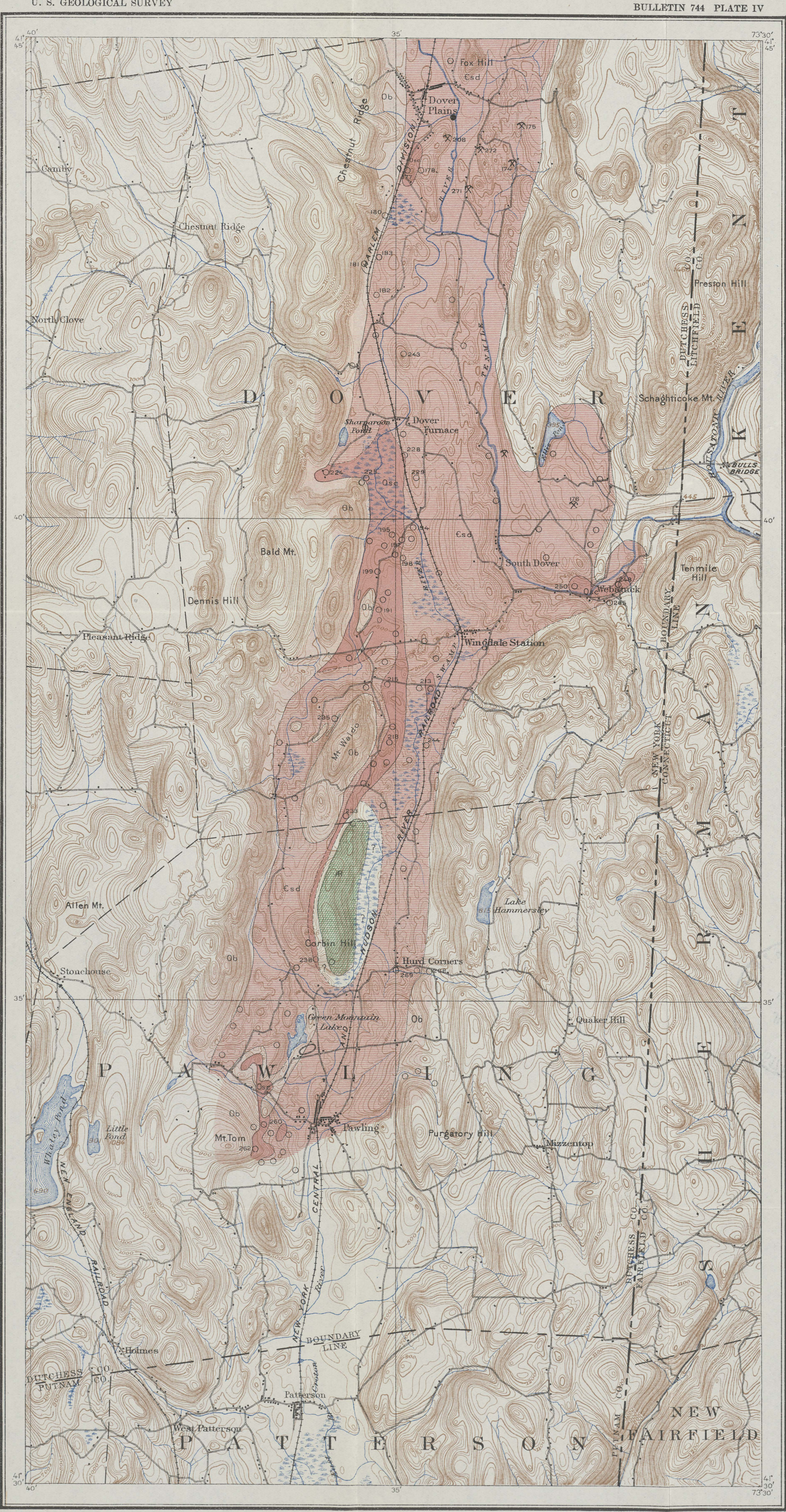

EXPLANATION

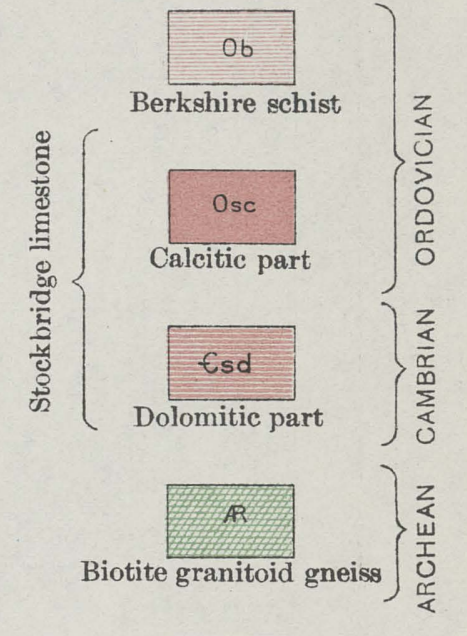

Area without outcrop

Age of underlying rock

Geologic boundary, approximate
location

Boundary very uncertai

Important outcrop

Lime kiln, active

(Kelley Island Lime \&

x
Quarry

Loc. $176=$ South Dover
Marble Co.'s quarry

Gopolgraphy by U.S.

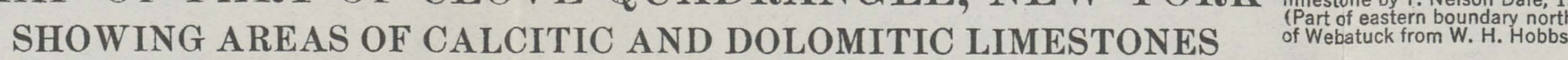

